\title{
The Discovery of Quinoxaline-Based Metathesis Catalysts from Synthesis of Grazoprevir (MK-5172)
}

Michael J. Williams*, Jongrock Kong*, Cheol K. Chung, Andrew Brunskill, Louis-Charles Campeau, and Mark McLaughlin

Department of Process and Analytical Chemistry, Merck Research Laboratories, Rahway, New Jersey o7065, USA

\section{Supporting Information}

General Information

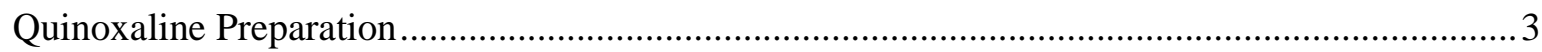

1-(tert-butyl) 2-methyl (2S,4R)-4-((3-(but-3-en-1-yl)-7-methoxyquinoxalin-2-

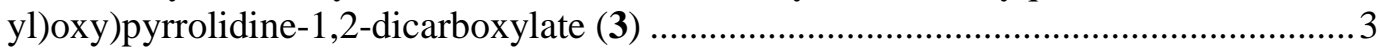

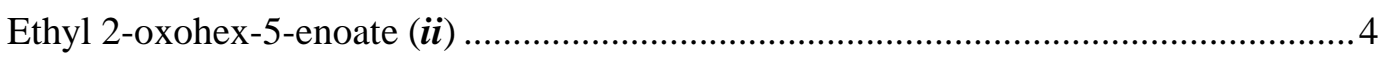

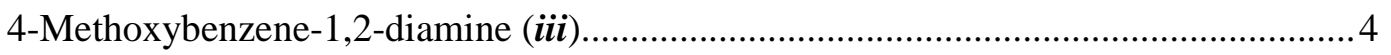

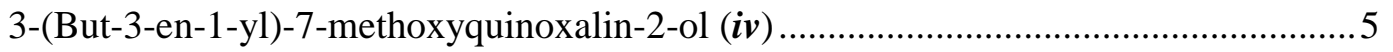

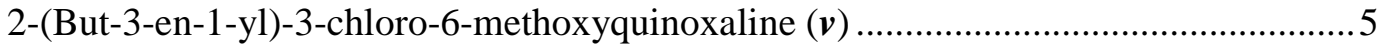

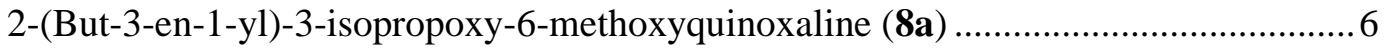

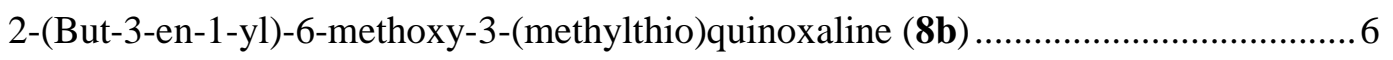

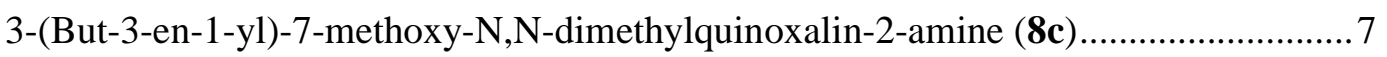

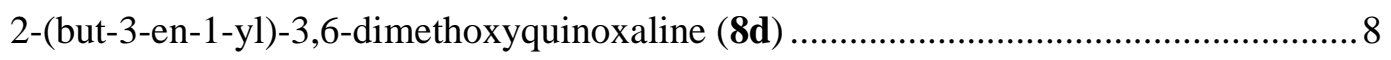

2-(but-3-en-1-yl)-3-(isopropylthio)-6-methoxyquinoxaline (8e) ................................ 8

2-(but-3-en-1-yl)-3-(isopropylsulfonyl)-6-methoxyquinoxaline (8f) ........................... 9

2-Chloro-3-isopropoxy-6-methoxyquinoxaline (vii) .............................................. 9

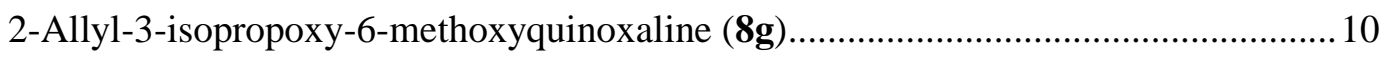

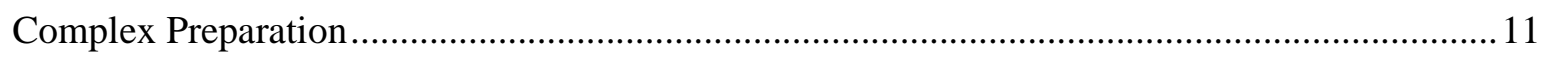

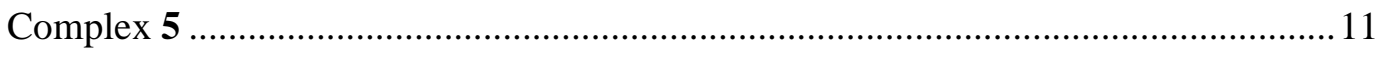

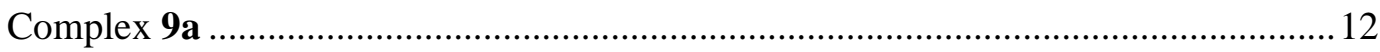

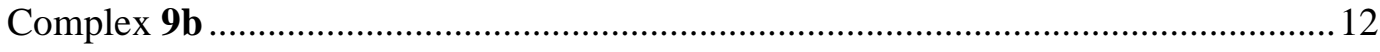

Complex 9c

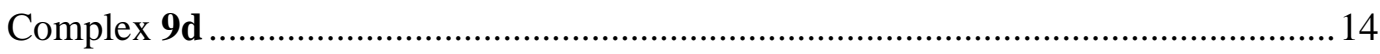

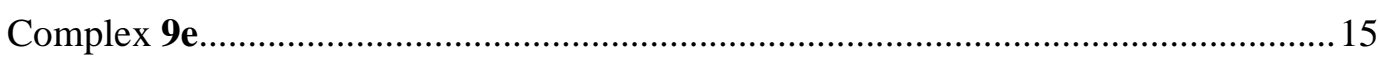

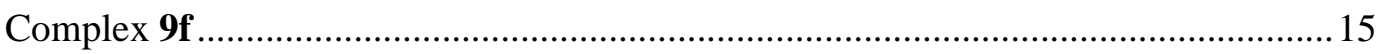




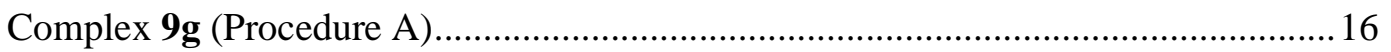

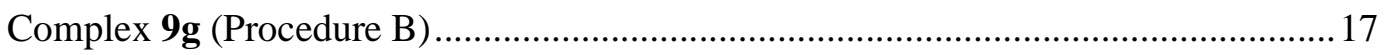

Crystal Data and Structure Refinement for Complex 9a (CCDC 1444069) ................................. 17

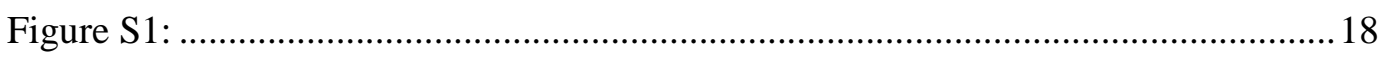

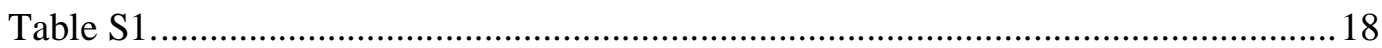

Experimental Procedure for Discovery of Quinoxaline-Based Complex 5.....................19

Experimental Procedures for Solution Stability Study of Complex 9a.......................................25

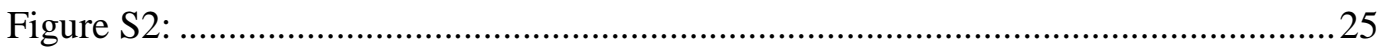

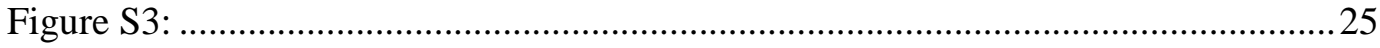

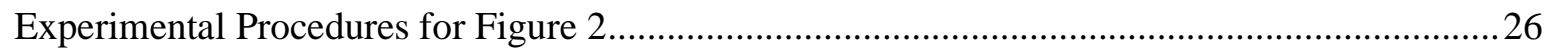

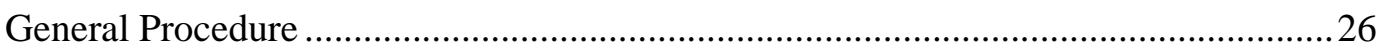

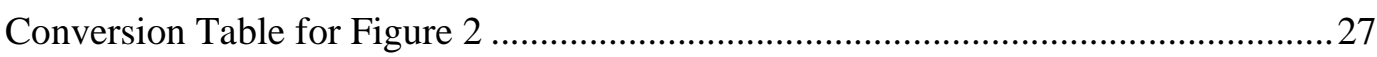

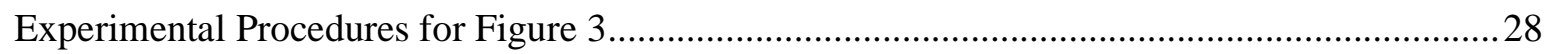

General procedure without acid co-catalyst: ........................................................2. 28

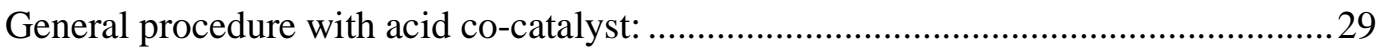

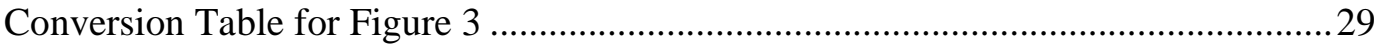

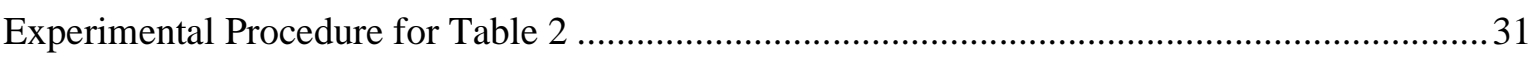

High-Throughput Experimentation General Procedure: .............................................. 31

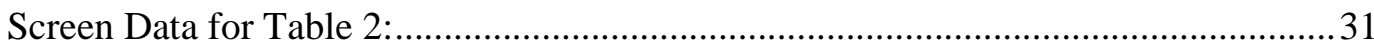

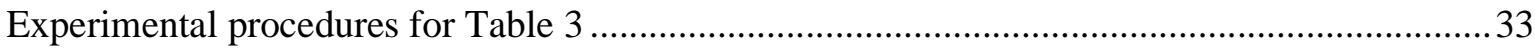

Ring-closing Metathesis Procedures (Table 3; Entries 1-8),..........................33

Representative Procedure for Isolation of RCM (Table 3; Entry 8)....................33

Ring-opening Metathesis Polymerization Procedure (Table 3; Entries 9-10) ................33

Cross-metathesis Procedures (Table 3; Entries 11-12) .................................................. 34

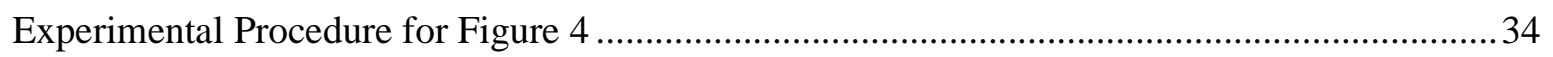

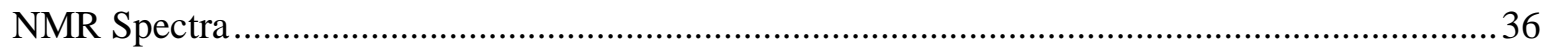

\section{General Information}

All reactions were carried out under a nitrogen atmosphere unless otherwise stated. All solvents and reagents were purchased from commercial sources and were used without further purification. ${ }^{1} \mathrm{H}$ and ${ }^{13} \mathrm{C}$ NMR chemical shifts were reported relative to residual proton solvent peaks, and were obtained on 400 or $500 \mathrm{MHz}$ spectrometer as noted. High resolution mass spectra (HRMS) were obtained on Accurate-Mass Time-of-Flight (TOF) mass spectrometer and 
reported as $\mathrm{m} / \mathrm{z}$ (relative intensity). Accurate masses are reported for the molecular ion as noted. For high through-put experimentation, all reagents were does in a glovebox to a 96 well aluminum-based vial rack designed to hold 96- 8x30 mm vials (Analytical Sales and Services, Inc. P\# 84001) containing parylene coated stir dowels (1.98 x $4.80 \mathrm{~mm})$ (V\&P Scientific, P\# 711D-1) and stirred on a tumble stirrer. Reagents were dosed to 96 well vials as solutions via an Eppendorf® Repeater ${ }^{\circledR}$ Xstream electronic pipettor s in a nitrogen filled glovebox. After sealing the vials using the aluminum vial rack cover equipped with silicone and PFA mats, the reactor was placed stirred via tumble stirring. The temperature of the reaction mixture was monitored using a thermocouple fixing inside of the aluminum vial rack, and the $25-30{ }^{\circ} \mathrm{C}$ reaction temperature was controlled by the ambient temperature of the glovebox and tumble stirrer unit.

\section{Known compounds}

The following compounds referred to in this communication have previously been reported in the literature: $13,{ }^{1} 14,{ }^{2} 15,{ }^{3}, 16^{3}, 17,{ }^{1} 18,{ }^{4} 19,{ }^{9} 20,{ }^{4} 21 .^{4}$

\section{Quinoxaline Preparation}

1-(tert-butyl) 2-methyl (2S,4R)-4-((3-(but-3-en-1-yl)-7-methoxyquinoxalin-2-yl)oxy)pyrrolidine1,2-dicarboxylate (3)

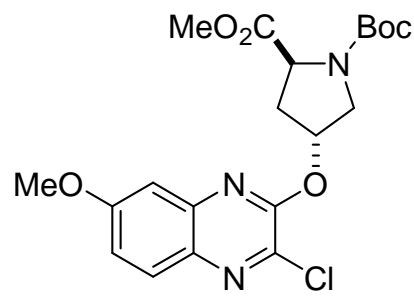

(i)

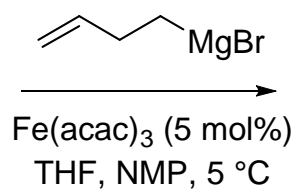

THF, NMP, $5{ }^{\circ} \mathrm{C}$

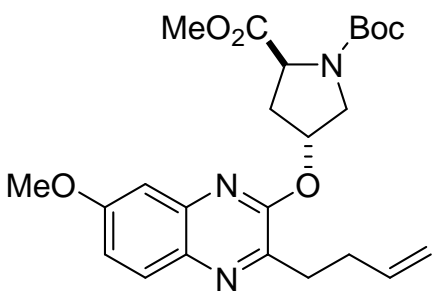

3

To $500 \mathrm{~mL}$ 3-neck round bottom flask was charged 1-(tert-butyl) 2-methyl (2S,4R)-4-((3-chloro7-methoxyquinoxalin-2-yl)oxy)pyrrolidine-1,2-dicarboxylate $(i)^{5}(20.0 \mathrm{~g}, 44.8 \mathrm{mmol}, 1.0$ equiv.), ferric acetylacetonate $(0.790 \mathrm{~g}, 2.238 \mathrm{mmol}, 0.05$ equiv. $)$, NMP (100 ml, 5X, KF = 333 $\mathrm{ppm})$, and then THF (100 ml, $5 \mathrm{X}, \mathrm{KF}=56 \mathrm{ppm})$ under $\mathrm{N}_{2}$. The reaction mixture was cooled between 0 and $10{ }^{\circ} \mathrm{C}$, and then 3-butenylmagnesium bromide (94 ml, $47.0 \mathrm{mmol}, 1.05$ equiv.) was charged dropwise to the reaction mixture keeping the internal temperature between 0 and 10 ${ }^{\circ} \mathrm{C}$ [Note: color went from red to brown to black upon addition]. The mixture was allowed to stir, and deemed complete (30 minutes) by HPLC analysis. The reaction was then quenched with $1 \mathrm{M} \mathrm{HCl}(100 \mathrm{ml}, 5 \mathrm{X})$ and $\mathrm{MTBE}(100 \mathrm{ml}, 5 \mathrm{X})$ keeping the internal temp below $25^{\circ} \mathrm{C}$,

\footnotetext{
${ }^{1}$ Matsugi, M; Kobayashi, Y.; Suzumura, N.; Tsuchiya, Y.; Shioiri, T. J. Org. Chem. 2010, 75, 7906.

${ }^{2}$ Yao, Q.; Zhang, Y. J. Am. Chem. Soc. 2004, 126, 74.

${ }^{3}$ Michalek F.; Mädge D.; Rühe, J.; Bannwarth, W. J. Orgomet. Chem. 2006, 691, 5172.

${ }^{4}$ Commercially available.

${ }^{5}$ Please see the following reference for the synthesis of compound $i$ : Kuethe, J.; Zhong, Y.-L.; Yasuda, N.; Beutner, G.; Linn, K.; Kim, M.; Marcune, B.; Dreher, S. D.; Humphrey, G.; Pei, T. Org. Lett. 2013, 15, 4174.
} 
where it was transferred to a separatory funnel, and the layers were separated. The resulting organic layer (dark black-red colored) was extracted with water $(100 \mathrm{ml}, 5 \mathrm{X})$ and then $10 \mathrm{wt} \%$ brine $(100 \mathrm{ml}, 5 \mathrm{X})$. The organic layer was assayed by HPLC and found to yield the desired product (3) (18.0 g, $39.2 \mathrm{mmol}, 88 \%$ yield). The resulting organic layer was concentrated to yield an orange opaque oil which was suitable for further manipulations or could be further purified via silica gel chromatography (340g Biotage SNAP Si gel column; loaded with 1:1 MTBE:hex; $15 \%$ to $50 \%$ EtOAc in hexanes over $8 \mathrm{col}$ vol. and then held; detect at $254 \& 290$ nm). ${ }^{1} \mathbf{H}$ NMR $\left(500 \mathrm{MHz}, \mathrm{CD}_{2} \mathrm{Cl}_{2}\right) \delta 7.80(\mathrm{dd}, J=8.7,3.8 \mathrm{~Hz}, 1 \mathrm{H}), 7.21-7.13(\mathrm{~m}, 2 \mathrm{H}), 5.93$ (ddt, $J=16.9,10.1,6.7 \mathrm{~Hz}, 1 \mathrm{H}), 5.80-5.69(\mathrm{~m}, 1 \mathrm{H}), 5.06(\mathrm{dq}, J=17.1,1.7 \mathrm{~Hz}, 1 \mathrm{H}), 4.97$ (ddt, $J=10.2,2.2,1.2 \mathrm{~Hz}, 1 \mathrm{H}), 4.49(\mathrm{dt}, J=19.2,7.9 \mathrm{~Hz}, 1 \mathrm{H}), 3.93(\mathrm{~s}, 3 \mathrm{H}), 3.91-3.85(\mathrm{~m}, 1 \mathrm{H}), 3.86$ $-3.67(\mathrm{~m}, 4 \mathrm{H}), 3.03-2.92(\mathrm{~m}, 2 \mathrm{H}), 2.69-2.56(\mathrm{~m}, 1 \mathrm{H}), 2.56-2.48(\mathrm{~m}, 2 \mathrm{H}), 2.38(\mathrm{ddd}, J=$ 13.4, 8.0, $5.1 \mathrm{~Hz}, 1 \mathrm{H}), 1.42(\mathrm{~d}, J=13.5 \mathrm{~Hz}, 9 \mathrm{H}) .{ }^{13} \mathrm{C}-\mathrm{NMR}\left(125 \mathrm{MHz}, \mathrm{CD}_{2} \mathrm{Cl}_{2}\right)$ : $\delta$ 173.3, 173.0, $160.3,155.3,153.5,147.3,141.0,137.9,134.3,129.1,118.3,114.8,105.9,80.1,74.2,73.6,58.2$, 57.9, 55.7, 52.4, 52.14, 52.10, 52.0, 36.6, 35.7, 32.5, 31.5, 31.4, 28.1, 27.9. $\quad$ ESI-HRMS (m/z): Calc'd for $\mathrm{C}_{24} \mathrm{H}_{32} \mathrm{~N}_{3} \mathrm{O}_{6}(\mathrm{M}+\mathrm{H})$ : 458.2286; Found: 458.2303 .

Ethyl 2-oxohex-5-enoate (ii)
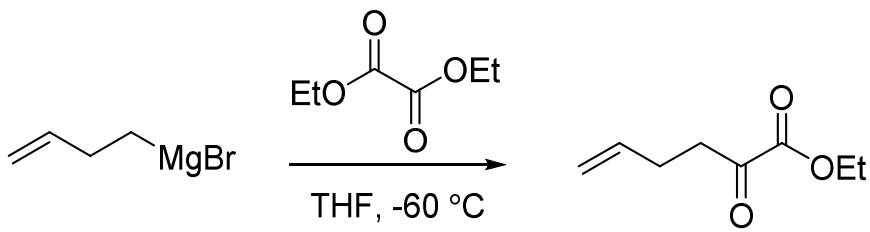

(ii)

To a solution of diethyl oxalate $(100 \mathrm{~g}, 684 \mathrm{mmol})$ in THF $(500 \mathrm{ml})$ at $-65^{\circ} \mathrm{C}$ was added 3-butenylmagnesium bromide (0.5 M in THF, $1382 \mathrm{ml}, 691 \mathrm{mmol})$ slowly to keep reaction temperature below $-60{ }^{\circ} \mathrm{C}$. The reaction was stirred at $-60{ }^{\circ} \mathrm{C}$ for $1 \mathrm{~h}$ to reach completion monitored by ${ }^{1} \mathrm{H}$ NMR. The reaction was diluted with MTBE $(1500 \mathrm{ml})$, quenched with $10 \mathrm{wt} \%$ citric acid $(1100 \mathrm{ml})$ at $-60{ }^{\circ} \mathrm{C}$, maintaining temperature below $-20{ }^{\circ} \mathrm{C}$. The reaction was warmed to RT. The organic layer was separated, washed with $10 \mathrm{wt} \%$ citric acid $(550 \mathrm{ml})$, followed by water wash $(600 \mathrm{ml})$. The organic layer was washed with saturated $\mathrm{NaHCO}_{3}\left(500 \mathrm{ml} \mathrm{X} \mathrm{2)}\right.$, followed by brine $(500 \mathrm{ml})$, dried over $\mathrm{MgSO}_{4}$, filtered, concentrated under vacuum to yield Ethyl 2-oxohex-5-enoate (ii) $(111.5,87 \%$ yield) as a pale yellow oil. The characterization data matched that of known reports. ${ }^{6}$

4-Methoxybenzene-1,2-diamine (iii)<smiles>COc1ccc(N)c([N+](=O)[O-])c1</smiles>

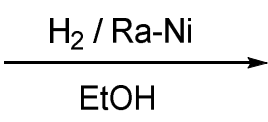<smiles>COc1ccc(N)c(N)c1</smiles>

(iii)

\footnotetext{
${ }^{6}$ Macritchie, J. A.; Silcock, A.; Willis, C. L. Tetrahedron Asymmetry, 1997, 8, 3895-3902.
} 
4-Methoxy-2-nitroaniline (27.0 g, $160 \mathrm{mmol})$ was dissolved in EtOH (300 ml). The reaction was flushed with $\mathrm{N}_{2}$, and Raney Ni pre-catalyst (14.0 g) was added. The reaction was hydrogenated under $45 \mathrm{psi}_{2}$ for $10 \mathrm{~h}$, (NOTE: The initial time period of this reaction is extremely exothermic. Care should be taken when conducting). The resulting mixture was filtered through a layer of CELITE囚, rinsed with EtOH $(60 \mathrm{ml})$, and the filtrate was concentrated to yield desired product (iii) as a dark brown solid (20 g), which was used in the next step without purification. Characterization data matched commercially available material. ${ }^{7}$

3-(But-3-en-1-yl)-7-methoxyquinoxalin-2-ol (iv)<smiles>C=CCCC(=O)C(=O)OCC</smiles>

To a solution of ethyl 2-oxohex-5-enoate (ii) $(7.27 \mathrm{~g}, 38.6 \mathrm{mmol})$ in EtOH (65.0 $\mathrm{ml}, 13 \mathrm{X})$ and water $(7.50 \mathrm{ml}, 1.5 \mathrm{X})$ at $50{ }^{\circ} \mathrm{C}$ was added a solution of 4-methoxybenzene-1, 2diamine (iii) (5 g, $35.1 \mathrm{mmol})$ in EtOH (10.00 $\mathrm{ml}, 2 \mathrm{X}$ ) through syringe pump (30 min) whereupon a slurry formed. The reaction mixture was then stirred and heated at $50{ }^{\circ} \mathrm{C}$ for $3 \mathrm{~h}$. The reaction reached completion, at which point the ratio of desired isomer to undesired isomer was 12 to 1 monitored by HPLC. The reaction mixture was cooled to RT. The precipitate was collected by filtration, rinsed with water $(2 \times 15 \mathrm{ml})$, dried under vacuum and $\mathrm{N}_{2}$ sweep overnight to yield desired product (iv) $\left(6.82 \mathrm{~g}, 85 \%\right.$ isolated yield) as an off white solid. ${ }^{1} \mathbf{H}$ NMR $\left(400 \mathrm{MHz}, \mathrm{CDCl}_{3}\right) \delta 11.75$ (br s, $\left.1 \mathrm{H}\right), 7.73(\mathrm{~d}, J=8.9 \mathrm{~Hz}, 1 \mathrm{H}), 6.93(\mathrm{dd}, J=8.9,2.7 \mathrm{~Hz}$, $1 \mathrm{H}), 6.73(\mathrm{~d}, J=2.6 \mathrm{~Hz}, 1 \mathrm{H}), 5.98(\mathrm{ddt}, J=16.8,10.2,6.6 \mathrm{~Hz}, 1 \mathrm{H}), 5.13(\mathrm{dq}, J=17.1,1.7 \mathrm{~Hz}$, $1 \mathrm{H}), 5.01$ (ddt, $J=10.2,2.0,1.2 \mathrm{~Hz}, 1 \mathrm{H}), 3.92(\mathrm{~s}, 3 \mathrm{H}), 3.09-2.99(\mathrm{~m}, 2 \mathrm{H}), 2.65-2.54(\mathrm{~m}, 2 \mathrm{H})$. ${ }^{13}$ C-NMR (100MHz, $\left.\mathrm{CDCl}_{3}\right): \delta 161.07,157.38,156.86,138.01,132.62,130.24,128.02,115.36$, 113.02, 98.23, 77.55, 77.43, 77.23, 76.91, 56.02, 32.71, 31.07. ESI-HRMS (m/z): Calc'd for $\mathrm{C}_{13} \mathrm{H}_{15} \mathrm{~N}_{2} \mathrm{O}_{2}(\mathrm{M}+\mathrm{H}): 231.1128$; Found: 231.1131 .

2-(But-3-en-1-yl)-3-chloro-6-methoxyquinoxaline (v)

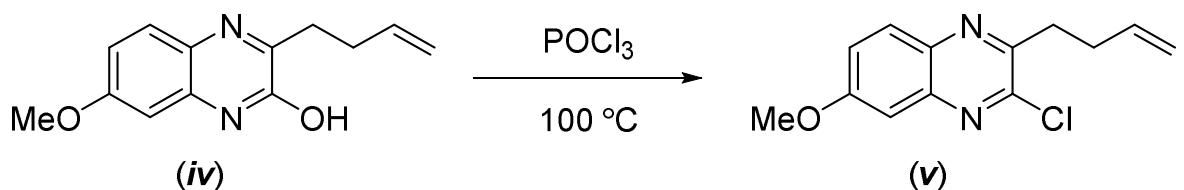

To 3-(but-3-en-1-yl)-7-methoxyquinoxalin-2-ol (iv) (4.63 g, $18.50 \mathrm{mmol}$ ) was charged $\mathrm{POCl}_{3}$ (17.24 ml, $185 \mathrm{mmol}, 10.0$ equiv.) to form a thick slurry. The mixture was heated to $100{ }^{\circ} \mathrm{C}$ and

\footnotetext{
${ }^{7}$ CAS [102-51-2]; commercially available as $\mathrm{HCl}$ salt
} 
judged complete $(1 \mathrm{~h})$ after HPLC analysis. The mixture was cooled to RT, and concentrated on a rotary evaporator to remove most of the $\mathrm{POCl}_{3}$. The resulting residue was quenched into a mixture of saturated $\mathrm{NaHCO}_{3}(200 \mathrm{~mL})$, ice $(200 \mathrm{~mL})$, and EtOAc $(300 \mathrm{~mL})$ with good agitation. The layers were split, and the organic layer was washed with brine $(100 \mathrm{~mL})$, dried over $\mathrm{MgSO}_{4}$, filtered and concentrated to afford the desired product $(v)(3.74 \mathrm{~g}, 75 \%)$ as an off-white solid. ${ }^{\mathbf{1}} \mathbf{H}$ NMR $\left(400 \mathrm{MHz}, \mathrm{CD}_{2} \mathrm{Cl}_{2}\right) \delta 7.90(\mathrm{~d}, J=9.2 \mathrm{~Hz}, 1 \mathrm{H}), 7.38(\mathrm{dd}, J=9.2,2.8 \mathrm{~Hz}, 1 \mathrm{H}), 7.27(\mathrm{~d}, J=$ $2.8 \mathrm{~Hz}, 1 \mathrm{H}), 5.98(\mathrm{ddt}, J=16.9,10.2,6.6 \mathrm{~Hz}, 1 \mathrm{H}), 5.12(\mathrm{dq}, J=17.1,1.7 \mathrm{~Hz}, 1 \mathrm{H}), 5.01$ (ddt, $J=$ $10.2,1.9,1.2 \mathrm{~Hz}, 1 \mathrm{H}), 3.95(\mathrm{~s}, 3 \mathrm{H}), 3.25-3.07(\mathrm{~m}, 2 \mathrm{H}), 2.62(\mathrm{tdt}, J=7.8,6.5,1.4 \mathrm{~Hz}, 2 \mathrm{H}) .{ }^{13} \mathrm{C}$ NMR $\left(100 \mathrm{MHz}, \mathrm{CD}_{2} \mathrm{Cl}_{2}\right) \delta 161.53,152.48,148.41,143.13,138.11,137.60,130.05,123.39$, 115.66, 106.52, 56.47, 35.25, 32.00. ESI-HRMS (m/z): Calc'd for $\mathrm{C}_{13} \mathrm{H}_{14} \mathrm{ClN}_{2} \mathrm{O}(\mathrm{M}+\mathrm{H})$ : 249.0789; Found: 249.0794.

2-(But-3-en-1-yl)-3-isopropoxy-6-methoxyquinoxaline (8a)

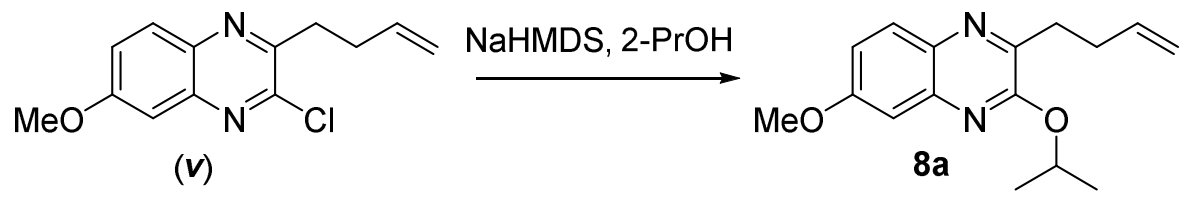

To a 250-mL round-bottom flask was charged 2-(but-3-en-1-yl)-3-chloro-6-methoxyquinoxaline (v) $(3.50 \mathrm{~g}, 14.07 \mathrm{mmol})$, isopropanol $(2.16 \mathrm{ml}, 28.1 \mathrm{mmol})$, and dimethylacetamide $(35 \mathrm{ml})$. The system was cooled in an ice/water bath and NaHMDS $(8.80 \mathrm{ml}, 17.6 \mathrm{mmol})$ was slowly charged to the reaction mixture via syringe. The mixture was allowed to stir at RT under $\mathrm{N}_{2}$ and judged complete $(72 \mathrm{~h})$ by HPLC analysis. The system was quenched with water $(100 \mathrm{~mL}), 1 \mathrm{M}$ $\mathrm{HCl}(50 \mathrm{~mL})$, and EtOAc $(100 \mathrm{~mL})$. The resulting biphasic system was split, and the aqueous layer extracted with EtOAc $(100 \mathrm{~mL})$. The organic layers were combined, washed with water $(50 \mathrm{~mL})$, washed with $10 \mathrm{wt} \%$ brine $(50 \mathrm{~mL})$, dried over $\mathrm{MgSO}_{4}$, filtered, and concentrated. The crude blackish oil was purified via silica gel chromatography (loaded with 1:1 DCM:hex; $220 \mathrm{~g}$ silica gel column (ISCO, Inc. Lincoln, NE, USA); eluted with 100\% hexanes for 1 column volume; then 0 to $30 \%$ EtOAc in hexanes over 10 column volumes) to yield the desired product (8a) (3.03 g, 79\% yield) as light yellow oil. ${ }^{1} \mathbf{H}$ NMR $\left(500 \mathrm{MHz}, \mathrm{CD}_{2} \mathrm{Cl}_{2}\right) \delta 7.79-7.74(\mathrm{~m}, 1 \mathrm{H})$, $7.15-7.10(\mathrm{~m}, 2 \mathrm{H}), 5.96$ (ddt, $J=16.9,10.2,6.6 \mathrm{~Hz}, 1 \mathrm{H}), 5.51$ (hept, $J=6.2 \mathrm{~Hz}, 1 \mathrm{H}$ ), 5.07 (dq, $J=17.1,1.7 \mathrm{~Hz}, 1 \mathrm{H}), 4.97(\mathrm{ddt}, J=10.2,2.2,1.2 \mathrm{~Hz}, 1 \mathrm{H}), 3.92(\mathrm{~s}, 3 \mathrm{H}), 3.01-2.93(\mathrm{~m}, 2 \mathrm{H})$, 2.55 (tdt, $J=7.8,6.4,1.4 \mathrm{~Hz}, 2 \mathrm{H}), 1.43(\mathrm{~d}, J=6.2 \mathrm{~Hz}, 6 \mathrm{H}) .{ }^{13} \mathrm{C}-\mathbf{N M R}\left(125 \mathrm{MHz}, \mathrm{CD}_{2} \mathrm{Cl}_{2}\right): \delta$ $160.7,156.6,148.5,142.0,138.9,134.4,129.6,118.0,115.1,106.4,69.5,56.2,33.2,31.9,22.2$. ESI-HRMS (m/z): Calc'd for $\mathrm{C}_{15} \mathrm{H}_{19} \mathrm{~N}_{2} \mathrm{O}_{2}(\mathrm{M}+\mathrm{H})$ : 259.1441; Found: 259.1460.

2-(But-3-en-1-yl)-6-methoxy-3-(methylthio)quinoxaline (8b)

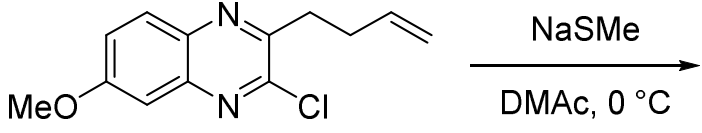

$(v)$<smiles>C=CCCc1nc2ccc(OC)cc2nc1SC</smiles>

8b 
To a 200-mL round-bottom flask were charged 2-(but-3-en-1-yl)-3-chloro-6methoxyquinoxaline (v) (3.00 g, $12.1 \mathrm{mmol}, 1.0$ equiv.) and $\mathrm{N}, \mathrm{N}$-dimethylacetamide (45.0 ml). The reaction mixture was cooled to $0{ }^{\circ} \mathrm{C}$, and sodium thiomethoxide $(1.860 \mathrm{~g}, 26.5 \mathrm{mmol}, 2.2$ equiv.) was charged as a solid. The reaction mixture was allowed to age at $0{ }^{\circ} \mathrm{C}$ and judged complete $(45 \mathrm{~min})$ by HPLC analysis. Water $(150 \mathrm{~mL})$ was then slowly charged to the reaction mixture, whereupon a white precipitate formed. The resulting slurry was warmed to RT and filtered. The resulting wet cake was washed with water $(3 \times 50 \mathrm{~mL})$, and dried on the filter with $\mathrm{N}_{2}$ and vacuum, yielding the desired product $(\mathbf{8 b})\left(3.01 \mathrm{~g}, 96 \%\right.$ yield) as an off-white solid. ${ }^{\mathbf{1}} \mathbf{H}$ NMR $\left(400 \mathrm{MHz}, \mathrm{CDCl}_{3}\right) \delta 7.87(\mathrm{dd}, J=8.7,0.8 \mathrm{~Hz}, 1 \mathrm{H}), 7.27-7.22(\mathrm{~m}, 2 \mathrm{H}), 5.99$ (ddt, $J=$ $16.9,10.2,6.6 \mathrm{~Hz}, 1 \mathrm{H}), 5.13(\mathrm{dq}, J=17.1,1.7 \mathrm{~Hz}, 1 \mathrm{H}), 5.03(\mathrm{dq}, J=10.2,1.3 \mathrm{~Hz}, 1 \mathrm{H}), 3.96(\mathrm{~s}$, $3 \mathrm{H}), 3.17-3.00(\mathrm{~m}, 2 \mathrm{H}), 2.69(\mathrm{~s}, 3 \mathrm{H}), 2.67-2.60(\mathrm{~m}, 2 \mathrm{H}) .{ }^{13} \mathbf{C} \mathbf{N M R}\left(100 \mathrm{MHz}, \mathrm{CDCl}_{3}\right) \delta$ $160.1,156.0,151.6,142.7,137.6,134.9,129.4,120.0,115.2,105.8,55.6,33.9,31.3,12.8$. ESIHRMS (m/z): Calc'd for $\mathrm{C}_{14} \mathrm{H}_{17} \mathrm{~N}_{2} \mathrm{OS}(\mathrm{M}+\mathrm{H})$ : 261.1056; Found: 261.1063.

3-(But-3-en-1-yl)-7-methoxy-N,N-dimethylquinoxalin-2-amine (8c)

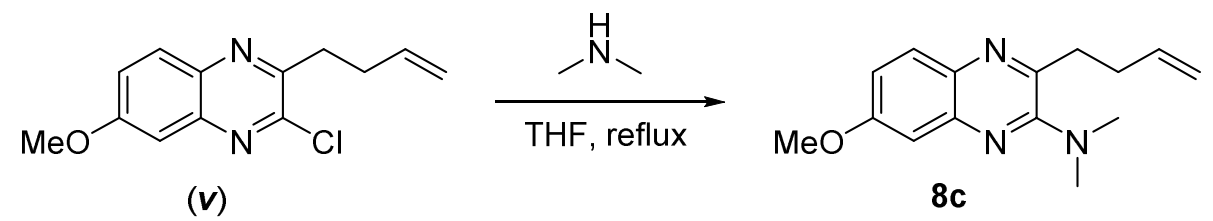

To a 250-mL round-bottom flask were charged 2-(but-3-en-1-yl)-3-chloro-6methoxyquinoxaline (v) (3.00 g, $12.06 \mathrm{mmol})$, dimethylacetamide $(22.5 \mathrm{ml})$, and dimethylamine (7.64 ml, $15.28 \mathrm{mmol}, 1.27$ equiv. as a $2.0 \mathrm{M}$ solution in THF). The reaction mixture was heated to $55{ }^{\circ} \mathrm{C}$, and judged incomplete $(5 \mathrm{~h})$ by HPLC analysis, and additional dimethylamine $(20 \mathrm{ml}$, $40 \mathrm{mmol}, 3.3$ equiv.) was charged to the mixture. The reaction was then heated $(10 \mathrm{~h})$ at $55^{\circ} \mathrm{C}$ and allowed to stir at room temperature over the weekend. The reaction mixture was judged complete ( $>90 \%$ conversion by HPLC analysis), and the reaction was quenched with water (200 $\mathrm{mL})$ and EtOAc $(75 \mathrm{~mL})$. The layers were split, and the aqueous layer was extracted again with EtOAc $(50 \mathrm{~mL})$. The organic layers were combined, washed with water $(100 \mathrm{~mL}), 10 \mathrm{wt} \% \mathrm{LiCl}$ (75 mL), dried over $\mathrm{MgSO}_{4}$, filtered, and concentrated. The resulting crude product was purified via silica gel chromatography (0 to $50 \%$ EtOAc in hexanes over 10 column volumes) to yield the desired product (8c) (2.76 g, 89\% yield) as light yellow oil. ${ }^{1} \mathbf{H}-\mathbf{N M R}\left(500 \mathrm{MHz}, \mathrm{CDCl}_{3}\right) \delta$ $7.78(\mathrm{~d}, J=9.0 \mathrm{~Hz}, 1 \mathrm{H}), 7.19(\mathrm{~d}, J=20.8 \mathrm{~Hz}, 1 \mathrm{H}), 7.13(\mathrm{dd}, J=9.0,2.8 \mathrm{~Hz}, 1 \mathrm{H}), 5.93(\mathrm{ddt}, J=$ 16.8, 10.2, 6.6, 1H), 5.09 (dq, $J=17.2,1.7 \mathrm{~Hz}, 1 \mathrm{H}), 4.98(\mathrm{dq}, J=10.2,1.4 \mathrm{~Hz}, 1 \mathrm{H}) .3 .93(\mathrm{~s}, 3 \mathrm{H})$, 3.12-2.90 (m, 8H), 2.66 - 2.61 (m, 2H). ${ }^{13}$ C-NMR (125 MHz, CDCl3): $\delta 160.2,156.7,148.4$, 138.0, 133.8, 128.8, 118.23, 115.0, 105.3, 55.6, 41.7, 34.4, 32.2. ESI-HRMS (m/z): Calc'd for $\mathrm{C}_{15} \mathrm{H}_{20} \mathrm{~N}_{3} \mathrm{O}(\mathrm{M}+\mathrm{H}): 258.1601$; Found: 258.1607. 
2-(but-3-en-1-yl)-3,6-dimethoxyquinoxaline (8d)

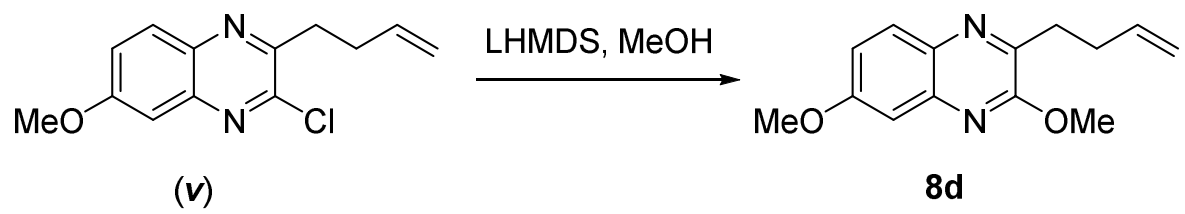

To a 250-mL flask were charged 2-(but-3-en-1-yl)-3-chloro-6-methoxyquinoxaline (v) (3.00 g, $12.1 \mathrm{mmol})$, dimethylacetamide $(45.0 \mathrm{ml})$, and then $\mathrm{MeOH}$ (2.79 ml, $69.0 \mathrm{mmol}, 5.7$ equiv.). The mixture was cooled in an ice/water bath below $5^{\circ} \mathrm{C}$, and LiHMDS (13.3 ml, $13.3 \mathrm{mmol}, 1.1$ equiv.) was charged keeping the internal temperature below $10{ }^{\circ} \mathrm{C}$. The reaction mixture was stirred for $10 \mathrm{~min}$ and then allowed to warm to RT. When the reaction mixture was judged complete $(23 \mathrm{~h})$ by HPLC analysis, the system was quenched with water $(100 \mathrm{~mL})$, EtOAc (100 $\mathrm{mL})$, and $1 \mathrm{M} \mathrm{HCl}(50 \mathrm{~mL})$. The resulting organic layer was washed with water $(2 \times 50 \mathrm{~mL})$, dried over $\mathrm{MgSO}_{4}$, filtered, and concentrated. The crude material was purified via silica gel chromatography (120 g silica gel column (ISCO, Inc. Lincoln, NE, USA), 0 to 50\% EtOAc in hexanes over 10 column volumes) to yield the desired product (8d) (2.47 g, 84\% yield) as light yellow oil, which crystallized to a white solid upon standing at $-20{ }^{\circ} \mathrm{C}$. ${ }^{1} \mathbf{H}$ NMR $(400 \mathrm{MHz}$, $\left.\mathrm{CDCl}_{3}\right) \delta 7.88-7.81(\mathrm{~m}, 1 \mathrm{H}), 7.23-7.13(\mathrm{~m}, 2 \mathrm{H}), 5.96(\mathrm{ddt}, J=16.9,10.2,6.6 \mathrm{~Hz}, 1 \mathrm{H}), 5.09$ $(\mathrm{dq}, J=17.1,1.7 \mathrm{~Hz}, 1 \mathrm{H}), 4.99(\mathrm{ddt}, J=10.2,2.0,1.2 \mathrm{~Hz}, 1 \mathrm{H}), 4.10(\mathrm{~s}, 3 \mathrm{H}), 3.94(\mathrm{~s}, 3 \mathrm{H}), 3.10-$ $2.98(\mathrm{~m}, 2 \mathrm{H}), 2.56(\mathrm{dtt}, J=9.2,6.3,1.4 \mathrm{~Hz}, 2 \mathrm{H}) .{ }^{13} \mathbf{C} \mathbf{N M R}\left(100 \mathrm{MHz}, \mathrm{CDCl}_{3}\right) \delta 160.2,156.8$, 147.3, 141.3, 137.9, 134.1, 129.2, 118.1, 115.0, 105.8, 55.6, 53.6, 32.5, 31.4. ESI-HRMS (m/z): Calc'd for $\mathrm{C}_{14} \mathrm{H}_{17} \mathrm{~N}_{2} \mathrm{O}_{2}(\mathrm{M}+\mathrm{H}): 245.1285$; Found: 245.1296 .

2-(but-3-en-1-yl)-3-(isopropylthio)-6-methoxyquinoxaline (8e)

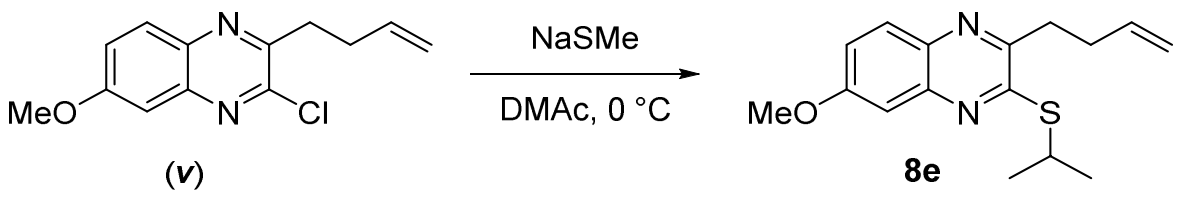

To a 100-mL round-bottom flask were charged 2-(but-3-en-1-yl)-3-chloro-6methoxyquinoxaline $(v)(3.99 \mathrm{~g}, 16.0 \mathrm{mmol}, 1.0$ equiv.) and dimethylformamide $(61.0 \mathrm{ml})$. After aging the reaction mixture over 5 minutes at room temperature, sodium propane-2-thiolate $(7.87 \mathrm{~g}, 80 \mathrm{mmol}, 5.0$ equiv) was charged to the reaction mixture. The reaction mixture was aged at room temperature over 1 hour. Water $(150 \mathrm{~mL})$ was then slowly charged to the reaction mixture, whereupon a white precipitate formed. The resulting slurry was then filtered. The wet cake was washed with water $(3 \times 50 \mathrm{~mL})$, and the cake was dried on the filter with $\mathrm{N}_{2}$ and vacuum. The further purification by $\mathrm{SiO}_{2}$ purification $(0-50 \%$ EtOAc to hexane $)$ yielded the desired product (8e) $\left(4.10 \mathrm{~g}, 89 \%\right.$ yield) as an off-white solid. ${ }^{1} \mathbf{H}$ NMR $\left(400 \mathrm{MHz}, \mathrm{CD}_{2} \mathrm{Cl}_{2}\right): \delta$ 
$7.88-7.76(\mathrm{~m}, 1 \mathrm{H}), 7.25(\mathrm{~d}, J=7.7 \mathrm{~Hz}, 2 \mathrm{H}), 6.02(\mathrm{ddt}, J=16.8,10.2,6.5 \mathrm{~Hz}, 1 \mathrm{H}), 5.15(\mathrm{dq}, J=$ $17.2,1.7 \mathrm{~Hz}, 1 \mathrm{H}$ ), 5.03 (ddt, $J=10.2,2.2,1.3 \mathrm{~Hz}, 1 \mathrm{H}$ ), 4.26 (hept, $J=6.8 \mathrm{~Hz}, 1 \mathrm{H}$ ), 3.98 (s, 3H), $3.12-2.87(\mathrm{~m}, 2 \mathrm{H}), 2.73-2.53(\mathrm{~m}, 2 \mathrm{H}), 1.52(\mathrm{~d}, J=6.9 \mathrm{~Hz}, 6 \mathrm{H}) .{ }^{13} \mathbf{C}-\mathbf{N M R}(100 \mathrm{MHz}$, $\left.\mathrm{CD}_{2} \mathrm{Cl}_{2}\right): \delta 160.1,156.2,151.7,142.7,138.0,134.9,129.4,119.8,114.8,105.9,55.7,34.9,33.9$, 31.1, 22.7. ESI-HRMS (m/z): Calc'd for $\mathrm{C}_{16} \mathrm{H}_{21} \mathrm{~N}_{2} \mathrm{OS}^{+}(\mathrm{M}+\mathrm{H})$ : 289.1369; Found: 289.1371 .

2-(but-3-en-1-yl)-3-(isopropylsulfonyl)-6-methoxyquinoxaline (8f)
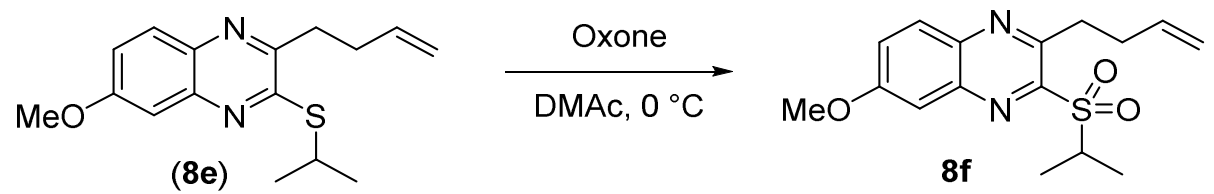

To a 250-mL round-bottom flask were charged 2-(but-3-en-1-yl)-3-(isopropylthio)-6methoxyquinoxaline (8e) $(2.76 \mathrm{~g}, 9.57 \mathrm{mmol})$ and $\mathrm{MeOH}(55.2 \mathrm{ml})$ was charged. Potassium peroxymonosulfate $\left(11.77 \mathrm{~g}, 19.14 \mathrm{mmol}\right.$, commercially known as Oxone $\left.{ }^{\circledR}\right)$ was added to the reaction, and the resulting heterogeneous solution was aged overnight at room temperature. The reaction was deemed complete by HPLC analysis and then quenched with water $(50 \mathrm{~mL})$ and EtOAc $(75 \mathrm{~mL})$. The layers were split, and the aqueous layer was extracted again with EtOAc $(50 \mathrm{~mL})$. The organic layers were combined, washed with water $(50 \mathrm{~mL})$, brine $(50 \mathrm{~mL})$, dried over $\mathrm{MgSO}_{4}$, filtered, and concentrated to yield yellow oil. The resulting crude product was purified via silica gel chromatography ( 0 to $50 \%$ EtOAc in hexanes over 20 column volumes) to yield the desired product $(\mathbf{8 f})\left(2.10 \mathrm{~g}, 69 \%\right.$ yield) as light yellow oil. ${ }^{\mathbf{1}} \mathbf{H}$ NMR $(500 \mathrm{MHz}$, $\left.\mathrm{CD}_{2} \mathrm{Cl}_{2}\right): \delta 8.00(\mathrm{~d}, J=9.2 \mathrm{~Hz}, 1 \mathrm{H}), 7.56(\mathrm{dd}, J=9.2,2.8 \mathrm{~Hz}, 1 \mathrm{H}), 7.40(\mathrm{~d}, J=2.8 \mathrm{~Hz}, 1 \mathrm{H}), 6.04$ (ddt, $J=16.9,10.2,6.6 \mathrm{~Hz}, 1 \mathrm{H}), 5.16(\mathrm{dq}, J=17.1,1.7 \mathrm{~Hz}, 1 \mathrm{H}), 5.04$ (ddt, $J=10.2,2.0,1.3 \mathrm{~Hz}$, 1H), 4.36 (hept, $J=6.9 \mathrm{~Hz}, 1 \mathrm{H}), 4.02(\mathrm{~s}, 3 \mathrm{H}), 3.56-3.49$ (m, 2H), $2.75-2.68(\mathrm{~m}, 2 \mathrm{H}), 1.49$ (d, $J=6.9 \mathrm{~Hz}, 6 \mathrm{H}) .{ }^{13} \mathrm{C}-\mathbf{N M R}\left(125 \mathrm{MHz}, \mathrm{CD}_{2} \mathrm{Cl}_{2}\right): \delta 161.3,151.3,151.1,140.4,139.1,137.8$, 129.6, 126.0, 115.0, 106.3, 56.0, 51.3, 33.8, 32.6, 15.1. ESI-HRMS (m/z): Calc'd for $\mathrm{C}_{16} \mathrm{H}_{21} \mathrm{~N}_{2} \mathrm{O}_{3} \mathrm{~S}^{+}(\mathrm{M}+\mathrm{H}): 321.1267$; Found: 321.1273 .

2-Chloro-3-isopropoxy-6-methoxyquinoxaline (vii)

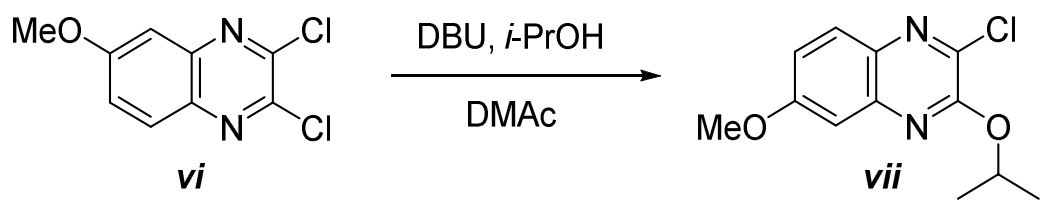

To a 100-mL round-bottom flask were charged 2,3-dichloro-6-methoxyquinoxaline (vi) (9.00 g, $39.3 \mathrm{mmol}), 2$-propanol $(3.31 \mathrm{~mL}, 43.2 \mathrm{mmol}), \mathrm{N}, \mathrm{N}$-dimethylacetamide $(45 \mathrm{~mL})$ and DBU $(7.62 \mathrm{~mL}, 51.1 \mathrm{~mL})$, and then system was warmed to $40{ }^{\circ} \mathrm{C}$. The reaction was aged at 40 ${ }^{\circ} \mathrm{C}$ for $48 \mathrm{~h}$, and then quenched with water $(10 \mathrm{~mL}), 1 \mathrm{M} \mathrm{HCl}(30 \mathrm{~mL})$, and EtOAc $(50 \mathrm{~mL})$. The layers were separated, and the aqueous layer was washed again with EtOAc $(50 \mathrm{~mL})$. The organic layers were combined, washed with water $(50 \mathrm{~mL}), 10 \mathrm{wt} \%$ brine $(50 \mathrm{~mL})$, dried over 
$\mathrm{MgSO}_{4}$, filtered and concentrated. The resulting material was purified via silica gel chromatography (loaded with toluene) and eluted with EtOAc and Hex (EtOAc:Hexane = 1:5) to yield the desired product (vii) (3.5 g, 35\% yield). ${ }^{1} \mathbf{H}$ NMR (400 MHz, $\left.\mathrm{CD}_{2} \mathrm{Cl}_{2}\right): \delta 7.79(\mathrm{~d}, J=$ $8.9 \mathrm{~Hz}, 1 \mathrm{H}), 7.28-7.16(\mathrm{~m}, 2 \mathrm{H}), 5.54$ (hept, $J=6.2 \mathrm{~Hz}, 1 \mathrm{H}), 3.97$ (s, 3H), 1.49 (d, $J=6.2 \mathrm{~Hz}$, 6H). ${ }^{13}$ C-NMR $\left(100 \mathrm{MHz}, \mathrm{CD}_{2} \mathrm{Cl}_{2}\right): \delta 161.1,153.1,141.4,136.6,133.4,128.7,118.8,105.7$, 71.0, 55.8, 21.5. ESI-HRMS (m/z): Calc'd for $\mathrm{C}_{12} \mathrm{H}_{14} \mathrm{ClN}_{2} \mathrm{O}_{2}+(\mathrm{M}+\mathrm{H})$ : 253.0738; Found: 253.0738 .

\section{2-Allyl-3-isopropoxy-6-methoxyquinoxaline $(\mathbf{8 g})$}

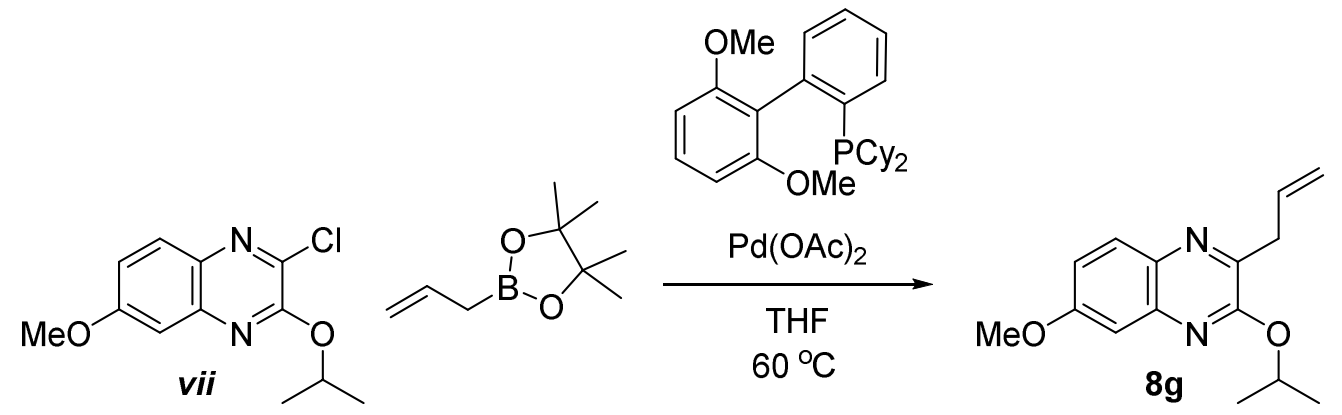

To a round-bottom flask was charged potassium phosphate tribasic ( $8.82 \mathrm{~g}, 41.6 \mathrm{mmol})$, 2-dicyclohexylphosphino-2',6'-dimethoxybiphenyl (0.569 g, 1.385 mmol), 2-chloro-3isopropoxy-6-methoxy quinoxaline (vii) $(3.5 \mathrm{~g}, 13.9 \mathrm{mmol})$ and palladium (II) acetate $(0.155 \mathrm{~g}$, $0.693 \mathrm{mmol})$. After the mixture was degassed, THF $(35 \mathrm{~mL})$ was charged followed by the slow addition of allylboronic acid pinacol ester $(5.20 \mathrm{~mL}, 27.7 \mathrm{mmol})$. Again, the system was again degassed, and then heated to $60{ }^{\circ} \mathrm{C}$ and aged overnight. After aging, the reaction was filtered to remove black insoluble particles, and the solids were subsequently washed with MTBE several times. The organic solution was transferred to a separatory funnel where water $(50 \mathrm{~mL})$ and EtOAc $(50 \mathrm{~mL})$ were then charged. The layers were split, and the aqueous layer was extracted with EtOAc $(50 \mathrm{~mL})$. The organic layers were combined, washed with water $(50 \mathrm{~mL}), 10 \mathrm{wt} \%$ brined $(50 \mathrm{~mL})$, dried over $\mathrm{MgSO}_{4}$, filtered and concentrated. The crude material was further purified via silica gel chromatography (loaded with toluene) and eluted with EtOAc:Hex (1:20) to yield the desired product $(\mathbf{8 g})(2.5 \mathrm{~g}, 70 \%)$ as light yellow oil. ${ }^{\mathbf{1}} \mathbf{H} \mathbf{N M R}\left(400 \mathrm{MHz}, \mathrm{CDCl}_{3}\right) \delta$ $7.83(\mathrm{~d}, J=8.7 \mathrm{~Hz}, 1 \mathrm{H}), 7.20-7.07(\mathrm{~m}, 2 \mathrm{H}), 6.14$ (ddt, $J=16.9,10.1,6.8 \mathrm{~Hz}, 1 \mathrm{H}), 5.52$ (hept, $J$ $=6.2 \mathrm{~Hz}, 1 \mathrm{H}), 5.22(\mathrm{dq}, J=17.1,1.6 \mathrm{~Hz}, 1 \mathrm{H}), 5.14(\mathrm{dq}, J=10.1,1.5 \mathrm{~Hz}, 1 \mathrm{H}), 3.93(\mathrm{~s}, 3 \mathrm{H}), 3.69$ $(\mathrm{dt}, J=6.8,1.4 \mathrm{~Hz}, 2 \mathrm{H}), 1.44(\mathrm{~d}, J=6.2 \mathrm{~Hz}, 6 \mathrm{H}) .{ }^{13} \mathbf{C} \mathbf{N M R}\left(100 \mathrm{MHz}, \mathrm{CDCl}_{3}\right): \delta 160.32$, 155.97, 146.39, 141.69, 134.06, 133.94, 129.33, 117.91, 117.11, 105.93, 69.05, 55.68, 38.21, 22.05. ESI-HRMS (m/z): Calc'd for $\mathrm{C}_{15} \mathrm{H}_{19} \mathrm{~N}_{2} \mathrm{O}_{2}+(\mathrm{M}+\mathrm{H})$ : 259.1441; Found: 259.1460. 


\section{Complex Preparation}

Note: where specifically stated, precatalysts $\mathbf{4 , 6 a}$ and $\mathbf{6 b}$ can be utilized to obtain similar results.

\section{Complex 5}

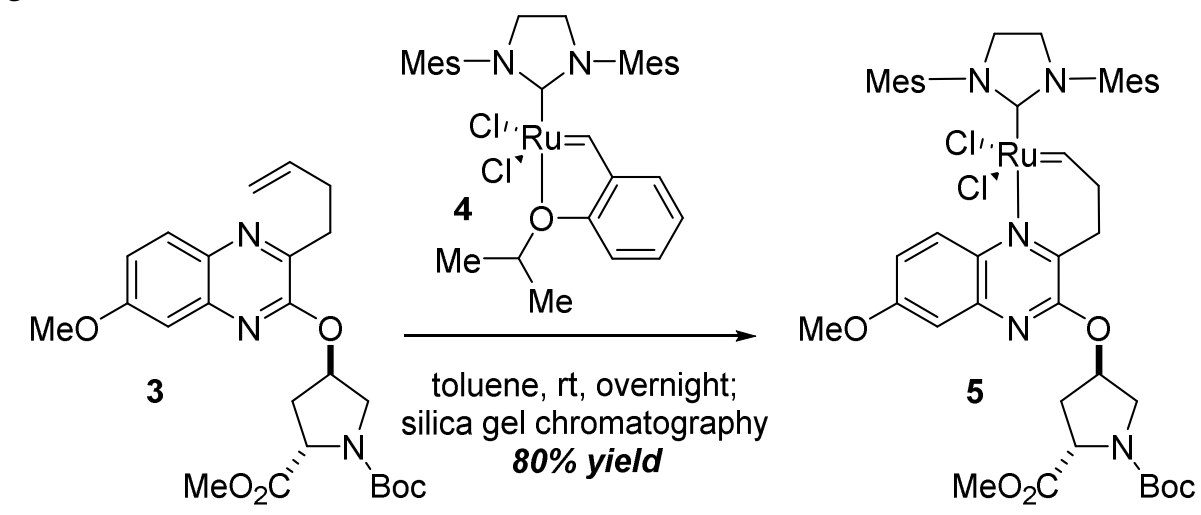

To a 3-neck flask was charged (2S,4R)-1-tert-butyl 2-methyl 4-((3-(but-3-en-1-yl)-7methoxyquinoxalin-2-yl)oxy)pyrrolidine-1,2-dicarboxylate (3) (1.00 g, $2.12 \mathrm{mmol}, 1.18$ equiv.) dichloromethane $(12.00 \mathrm{ml})$, and then Hoveyda-Grubbs $2^{\text {nd }}$ generation precatalyst (4) $(1.129 \mathrm{~g}$, 1.802 mmol, 1.00 equiv.) was then charged to the mixture as a solid under a stream of $\mathrm{N}_{2} .{ }^{1} \mathrm{H}$ NMR analysis of the crude reaction mixture (16h) indicated a ratio of 10:1 (Complex $5: 4$ ). The reaction was then directly loaded to a $120 \mathrm{~g}$ silica gel column and eluted with hexanes/EtOAc from $5 \%$ to $50 \%$ EtOAc in hexanes over 10 column volumes to yield complex 5 (1.34 g, 1.45 mmol, $80 \%$ yield) as a red-brown solid. ${ }^{1} \mathbf{H}$ NMR $\left(400 \mathrm{MHz}, \mathrm{CD}_{2} \mathrm{Cl}_{2}\right) \delta 18.41(\mathrm{t}, \mathrm{J}=4.6 \mathrm{~Hz}$, $1 \mathrm{H}), 7.28-6.94(\mathrm{~m}, 6 \mathrm{H}), 6.74(\mathrm{dd}, \mathrm{J}=9.2,2.8 \mathrm{~Hz}, 1 \mathrm{H}), 5.62(\mathrm{dtt}, \mathrm{J}=22.6,5.1,2.5 \mathrm{~Hz}, 1 \mathrm{H})$, $4.43(\mathrm{dt}, \mathrm{J}=27.5,7.8 \mathrm{~Hz}, 1 \mathrm{H}), 4.19-3.97(\mathrm{~m}, 4 \mathrm{H}), 3.95-3.62(\mathrm{~m}, 8 \mathrm{H}), 3.28-3.18(\mathrm{~m}, 2 \mathrm{H})$, $2.83(\mathrm{ddd}, \mathrm{J}=11.7,5.8,3.3 \mathrm{~Hz}, 2 \mathrm{H}), 2.76-2.24(\mathrm{~m}, 21 \mathrm{H}), 1.42(\mathrm{~d}, \mathrm{~J}=7.7 \mathrm{~Hz}, 9 \mathrm{H}) .{ }^{13} \mathbf{C} \mathbf{~ N M R}$ $\left(100 \mathrm{MHz}, \mathrm{CD}_{2} \mathrm{Cl}_{2}\right)^{8}: \delta 216.04,215.95,173.73,173.45,160.80,155.24,154.69,153.97,149.14$, 149.04, 141.58, 140.82 (br), 139.39 (br), 139.00 (br), (138.17 (tol-d 8 )), 137.91 (br), 137.71 (br), 135.65 (br), 134.45, 130.18, 130.04, (129.34, 129.11, 128.87, 128.45, 128.21, 127.97 - tol- $\left.d_{8}\right)$, 126.72, (125.55, 125.31, 125.06 - tol- $\left.d_{8}\right)$ 118.81, 118.75, 107.02, 80.69, 80.63, 75.61, 74.98, 58.62, 58.40, 56.26, 52.86, 52.62, 52.56, 52.53, 52.44, 52.26 (br), 51.44 (br), 37.01, 36.15, 28.63, 28.53, 26.05, 21.73 (br), 21.49 (br), (21.17, 20.99, 20.80, 20.43, 20.23 - tol- $\left.d_{8}\right), 20.58$ (br), 18.59 (br). ESI-HRMS (m/z): Calc'd for $\mathrm{C}_{44} \mathrm{H}_{56} \mathrm{Cl}_{2} \mathrm{~N}_{5} \mathrm{O}_{6} \mathrm{Ru}(\mathrm{M}+\mathrm{H})$ : 922.2651; Found: 922.2537.

\footnotetext{
${ }^{8}$ Note: for characterization, the complex was solvent switched with toluene- $d_{8}$ to remove troublesome residual hexane and ethyl acetate. Subsequently, the toluene- $d_{8}$ was difficult to remove post solvent switch and can be observed in the ${ }^{13} \mathrm{C}$ NMR. The solvent peaks in the ${ }^{13} \mathrm{C}$ NMR are specifically noted in the spectral peak list.
} 


\section{Complex 9a}

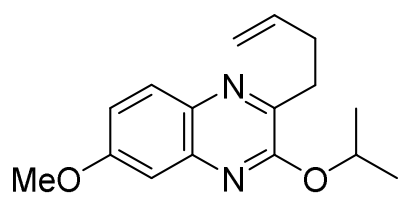

$8 a$
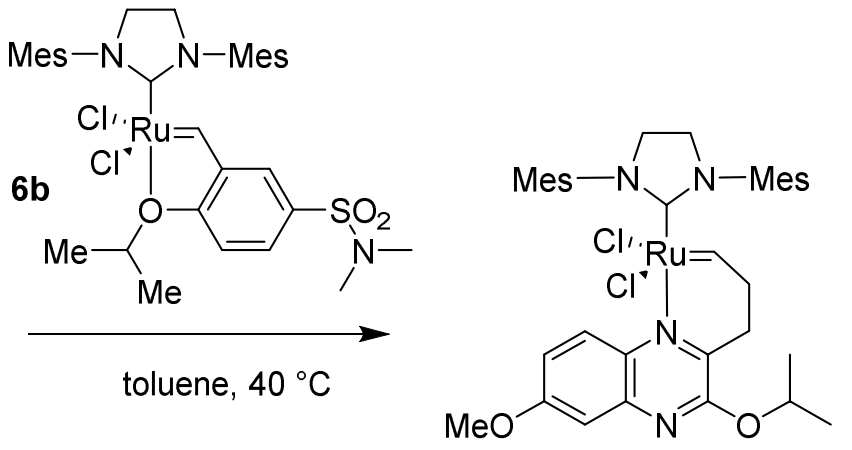

9a

To a round-bottom flask was charged 2-(but-3-en-1-yl)-3-isopropoxy-6-methoxyquinoxaline (8a) (0.98 g, 3.60 mmol, 2.64 equiv.). The system was purged with $\mathrm{N}_{2}$, and degassed toluene (3.00 $\mathrm{ml})$ was charged to the system under inert handling. Pre-catalyst $6 \mathbf{b}(1.00 \mathrm{~g}, 1.363 \mathrm{mmol}$, commercially available as Zhan $1 \mathrm{~B}$ ) was charged to the system under a stream of $\mathrm{N}_{2}$, and the system was sealed. The walls of the flask were then washed with degassed toluene $(2 \mathrm{~mL})$. The system was heated and aged at $40{ }^{\circ} \mathrm{C}$, where it was judged complete by ${ }^{1} \mathrm{H}$ NMR and TLC analysis $(30 \mathrm{~min})$. The mixture was treated with hexanes $(10.00 \mathrm{ml})$ dropwise at $40{ }^{\circ} \mathrm{C}$ was then allowed to cool to room temperature and aged $(1 \mathrm{~h})$. The red slurry was filtered through a sintered funnel, and the solid was slurry washed with $3: 1$ hexanes:toluene $(20 \mathrm{~mL} ; 2 \times 10 \mathrm{~mL}$ portions), and then hexanes ( $40 \mathrm{~mL} ; 4 \times 10 \mathrm{~mL}$ portions) to yield the desired product (9a) (985 $\mathrm{mg}, 98 \%$ yield) as a light red solid after drying in a vacuum oven at RT. ${ }^{1} \mathrm{H}-\mathrm{NMR}(500 \mathrm{MHz}$, $\left.\mathrm{CD}_{2} \mathrm{Cl}_{2}\right) \delta 18.40(\mathrm{t}, J=4.7 \mathrm{~Hz}, 1 \mathrm{H}), 7.28-7.11(\mathrm{~m}, 2 \mathrm{H}), 7.11-6.96(\mathrm{~m}, 4 \mathrm{H}), 6.67(\mathrm{dd}, J=9.1$, $2.9 \mathrm{~Hz}, 1 \mathrm{H}), 5.39$ (hept, $J=6.2 \mathrm{~Hz}, 1 \mathrm{H}), 4.08(\mathrm{~d}, J=26.2 \mathrm{~Hz}, 4 \mathrm{H}), 3.88(\mathrm{~s}, 3 \mathrm{H}), 3.32-3.11(\mathrm{~m}$, $2 \mathrm{H}), 2.96-2.78(\mathrm{~m}, 2 \mathrm{H}), 2.73-2.29(\mathrm{~m}, 18 \mathrm{H}), 1.40-1.33(\mathrm{~d}, J=6.2 \mathrm{~Hz}, 6 \mathrm{H}) .{ }^{13} \mathrm{C}-\mathrm{NMR}$ $\left(125 \mathrm{MHz}, \mathrm{CD}_{2} \mathrm{Cl}_{2}\right.$ ): $\delta$ 216.4, 160.6, 155.9, 149.7, 142.0, 140.8 (br), 139.4 (br), 139.0 (br), 137.9 (br), 137.7 (br), 135.7 (br), 133.8, 130.5 (br), 130.2 (br), 130.0, 129.5, 128.7, 126.5, 125.8, 117.9, 106.9, 70.4, 56.2, 54.5, 54.3, 52.5, 52.2 (br), 51.4 (br), 26.1, 22.1, 21.7 (br), 21.4 (br), 20.5 (br), 18.6 (br). ESI-HRMS (m/z): Calc'd for $\mathrm{C}_{36} \mathrm{H}_{45} \mathrm{Cl}_{2} \mathrm{~N}_{4} \mathrm{O}_{2} \mathrm{Ru}(\mathrm{M}+\mathrm{H})$ : 737.1963; Found: 737.1932.

\section{Complex 9b}

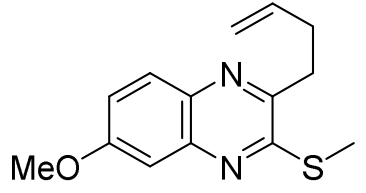

$8 \mathbf{b}$
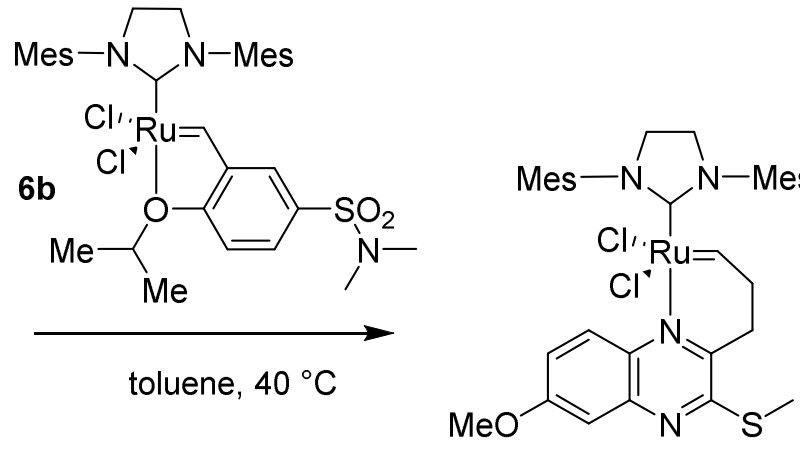

$9 b$ 
To a round-bottom flask was charged 2-(but-3-en-1-yl)-6-methoxy-3-(methylthio)quinoxaline (8b) (0.797 g, $3.06 \mathrm{mmol}, 2.25$ equiv.), and purged with $\mathrm{N}_{2}$. After toluene $(3.00 \mathrm{ml})$ and precatalyst 6b (1.00 g, $1.361 \mathrm{mmol}$, commercially available as Zhan 1B) were charged under a stream of $\mathrm{N}_{2}$, the system was sealed, and the walls were washed with additional toluene $(2 \mathrm{~mL})$. The resulting mixture was aged $(3 \mathrm{~h})$ at $40{ }^{\circ} \mathrm{C}$, deemed complete by ${ }^{1} \mathrm{H} \mathrm{NMR}$, and hexanes $(10.00 \mathrm{ml})$ were charged at $40{ }^{\circ} \mathrm{C}$. The resulting slurry was then allowed to cool to RT, filtered through a sintered funnel, washed in 2 portions with $25 \%$ toluene in hexane $(20.00 \mathrm{ml} ; 2 \times 10$ $\mathrm{mL}$ ), and then washed with 4 portions of hexanes $(40.0 \mathrm{ml} ; 4 \times 10 \mathrm{~mL})$. The resulting wet cake was dried in a vacuum oven to yield the desired product (981 $\mathrm{mg}, 97 \%$ yield) as a deep red solid. ${ }^{1} \mathbf{H}$ NMR $\left(400 \mathrm{MHz}, \mathrm{CD}_{2} \mathrm{Cl}_{2}\right) \delta 18.31(\mathrm{t}, J=4.6 \mathrm{~Hz}, 1 \mathrm{H}), 7.32-6.93(\mathrm{~m}, 6 \mathrm{H}), 6.76$ (ddd, $J=$ 9.3, 3.0, $1.2 \mathrm{~Hz}, 1 \mathrm{H}), 4.08$ (br d, $J=16.0 \mathrm{~Hz}, 4 \mathrm{H}), 3.90(\mathrm{~d}, J=1.2 \mathrm{~Hz}, 3 \mathrm{H}), 3.26-3.20(\mathrm{~m}, 2 \mathrm{H})$, 2.78 (ddt, $\mathbf{J}=8.2,4.8,2.3 \mathrm{~Hz}, 2 \mathrm{H}), 2.75-2.19(\mathrm{~m}, 21 \mathrm{H}) .{ }^{13} \mathbf{C} \mathbf{N M R}\left(100 \mathrm{MHz}, \mathrm{CD}_{2} \mathrm{Cl}_{2}\right) \delta$ 215.7, 160.6, 157.2, 153.3, 143.5, 140.8 (br), 139.4 (br), 139.0 (br), 137.9 (br), 137.7 (br), 135.8 (br), 135.0, 130.5, 130.1, 130.0, 126.9, 120.2, 106.9, 56.3, 54.4, 52.6, 52.3, 51.5, 28.4, 21.7 (br), 21.5 (br), 20.5 (br), 18.6 (br), 13.9. ESI-HRMS (m/z): Calc'd for $\mathrm{C}_{14} \mathrm{H}_{17} \mathrm{~N}_{2} \mathrm{OS}(\mathrm{M}+\mathrm{H})$ : 725.1422; Found: 725.1411.

\section{Complex 9c}

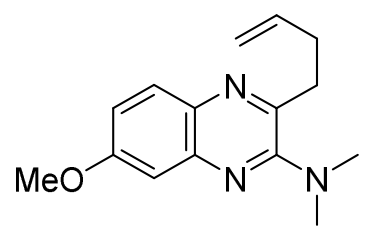

8c

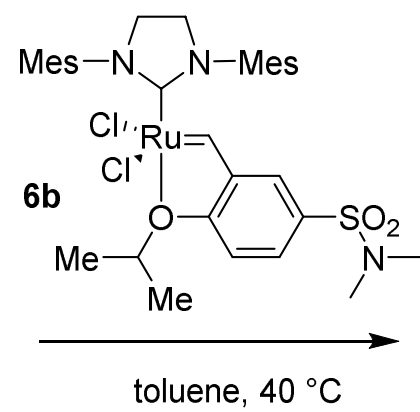

toluene, $40^{\circ} \mathrm{C}$

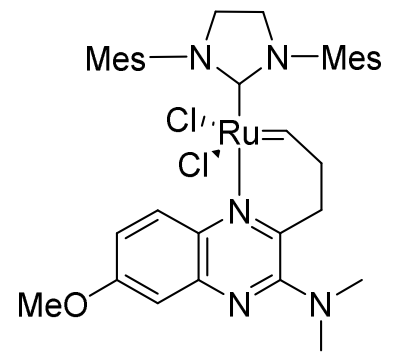

9c

To a round-bottom flask was charged 3-(but-3-en-1-yl)-7-methoxy-N,N-dimethylquinoxalin-2amine (8c) (0.788 g, $3.06 \mathrm{mmol}, 2.25$ equiv.), and the system was purged with $\mathrm{N}_{2}$. Toluene (3.00 $\mathrm{ml}$ ) was charged to the system under inert handling; pre-catalyst $6 \mathbf{b}(1.00 \mathrm{~g}, 1.361 \mathrm{mmol}$, commercially available as Zhan 1B) was charged under a stream of $\mathrm{N}_{2}$; the system was sealed; and toluene $(2 \mathrm{~mL})$ was utilized to wash down the walls of the flask. The system was aged at $40{ }^{\circ} \mathrm{C}$ until judged complete by ${ }^{1} \mathrm{H}$ NMR. Addition hexanes $(10.00 \mathrm{ml})$ were changed at $40{ }^{\circ} \mathrm{C}$. The resulting mixture was allowed to age for approximately $1 \mathrm{~h}$ at RT, then filtered through a sintered funnel, washed in two portions with $25 \%$ toluene in hexanes $(20.00 \mathrm{ml} ; 2 \mathrm{x} 10 \mathrm{~mL})$, and in four portions with hexanes $(40.0 \mathrm{ml} ; 4 \times 10 \mathrm{~mL})$. The resulting wet cake was dried on the filter with vacuum and $\mathrm{N}_{2}$ purge to yield the desired product (9c) (962 mg, 98\% yield) as a red solid. ${ }^{1}$ H-NMR $\left(500 \mathrm{MHz}, \mathrm{CD}_{2} \mathrm{Cl}_{2}\right) \delta 18.28(\mathrm{t}, J=4.0 \mathrm{~Hz}, 1 \mathrm{H}), 7.29-6.96(\mathrm{~m}, 5 \mathrm{H}), 6.91(\mathrm{~d}, J=$ $9.1 \mathrm{~Hz}, 1 \mathrm{H}), 6.63(\mathrm{dd}, J=9.1,2.9 \mathrm{~Hz}, 1 \mathrm{H}), 4.08$ (d, $J=21.8 \mathrm{~Hz}, 4 \mathrm{H}), 3.87(\mathrm{~s}, 3 \mathrm{H}), 3.51-3.28$ (m, 2H), $2.88(\mathrm{~s}, 6 \mathrm{H}), 2.77-2.26(\mathrm{~m}, 18 \mathrm{H}) .{ }^{13} \mathrm{C}-\mathrm{NMR}\left(125 \mathrm{MHz}, \mathrm{CD}_{2} \mathrm{Cl}_{2}\right): \delta$ 215.6, 160.5, 
157.6, 151.2, 142.4, 140.8 (br), 139.3 (br), 138.9 (br), 138.0 (br), 137.8 (br), 135.8, 135.7 (br), 134.3, 130.5 (br), 130.1 (br), 129.9, 129.5, 128.7, 126.5, 125.8, 125.4, 117.9, 106.5, 56.2, 54.5, 54.3, 54.1, 52.3 (br), 51.4 (br), 41.3, 21.7 (br), 21.4 (br), 20.6 (br), 19.4 (br), 18.6 (br). ESIHRMS (m/z): Calc'd for $\mathrm{C}_{35} \mathrm{H}_{44} \mathrm{Cl}_{2} \mathrm{~N}_{5} \mathrm{ORu}(\mathrm{M}+\mathrm{H})$ : 722.1966; Found: 722.1967.

\section{Complex 9d}

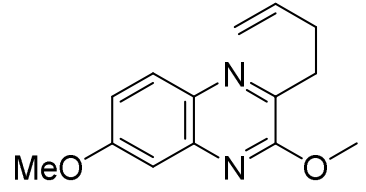

8d

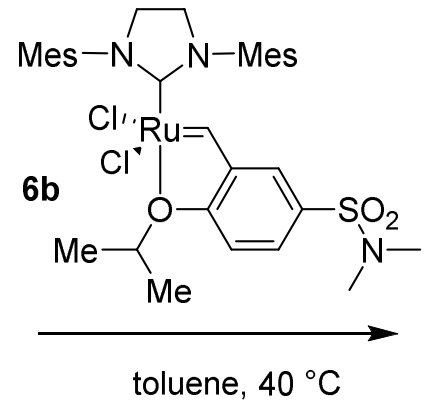

To a round-bottom flask was charged 2-(but-3-en-1-yl)-3,6-dimethoxyquinoxaline (8d) (0.916 g, $3.75 \mathrm{mmol}, 2.25$ equiv.), and then the system was purged with $\mathrm{N}_{2}$. Toluene $(3.00 \mathrm{ml})$ was charged to the system under inert handling, pre-catalyst $\mathbf{6 b}(1.00 \mathrm{~g}, 1.363 \mathrm{mmol}$, commercially available as Zhan 1B) was then charged under a stream of $\mathrm{N}_{2}$, and the system was sealed. Toluene $(2.0 \mathrm{~mL})$ was utilized to wash the sides of the flask. The system was aged at $40{ }^{\circ} \mathrm{C}(45$ min) until judged complete by ${ }^{1} \mathrm{H}$ NMR. Hexanes $(15.00 \mathrm{ml})$ were added dropwise at $40{ }^{\circ} \mathrm{C}$, and then the mixture was allowed to cool to RT and to age for $1 \mathrm{~h}$. To the resulting slurry was further added $25 \%$ toluene in hexane $(20.00 \mathrm{ml})$. The slurry was filtered through a sintered funnel, and the solid was slurry washed with hexanes $(40.0 \mathrm{ml} ; 4 \times 10 \mathrm{~mL})$ to yield the desired product (9d) (984 mg, 99\% yield) as an orange solid. ${ }^{1} \mathbf{H} \mathbf{N M R}\left(400 \mathrm{MHz}, \mathrm{CD}_{2} \mathrm{Cl}_{2}\right) \delta 18.40$ (t, $J$ $=4.6 \mathrm{~Hz}, 1 \mathrm{H}), 7.36-6.91(\mathrm{~m}, 6 \mathrm{H}), 6.70(\mathrm{dd}, J=9.2,2.9 \mathrm{~Hz}, 1 \mathrm{H}), 4.32-4.03(\mathrm{~m}, 4 \mathrm{H}), 4.00(\mathrm{~s}$, $3 \mathrm{H}), 3.88(\mathrm{~s}, 3 \mathrm{H}), 3.23(\mathrm{t}, J=6.3 \mathrm{~Hz}, 2 \mathrm{H}), 2.83(\mathrm{dt}, J=7.1,5.0 \mathrm{~Hz}, 2 \mathrm{H}), 2.76-2.23(\mathrm{~m}, 18 \mathrm{H})$. ${ }^{13}$ C NMR (400 MHz, $\left.\mathrm{CD}_{2} \mathrm{Cl}_{2}\right) \delta 216.2,160.7,156.7,149.3,141.9,140.8$ (br), 139.4 (br), 139.0 (br), 137.9 (br), 137.7 (br), 135.7 (br), 134.2, 130.1 (br), 130.0 (br), 129.5, 128.7, 126.7, 125.8, 118.3, 107.0, 56.2, 52.5, 52.2 (br), 51.4 (br), 27.3, 26.1, 21.7 (br), 21.5 (br), 20.5 (br), 18.6 (br). ESI-HRMS (m/z): Calc'd for $\mathrm{C}_{34} \mathrm{H}_{41} \mathrm{Cl}_{2} \mathrm{~N}_{4} \mathrm{O}_{2} \mathrm{Ru}(\mathrm{M}+\mathrm{H})$ : 709.1650; Found: 709.1544. 


\section{Complex 9e}

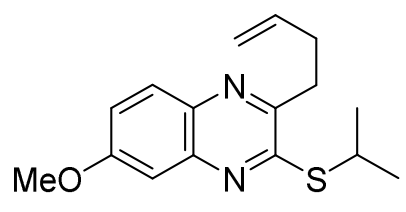

$8 \mathrm{e}$

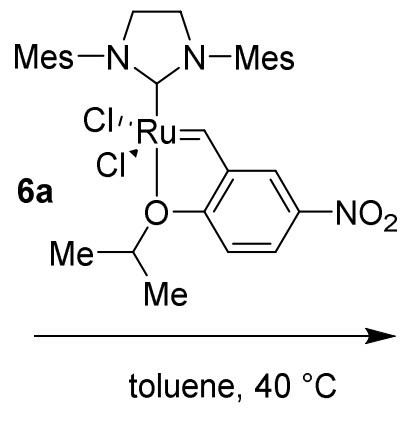

To a round-bottom flask was charged 2-(but-3-en-1-yl)-3-(isopropylthio)-6-methoxyquinoxaline (8e) (0.644 g, $2.23 \mathrm{mmol}, 1.5$ equiv.), and purged with $\mathrm{N}_{2}$. After toluene (5.00 ml) and precatalyst 6a $(1.00 \mathrm{~g}, 1.49 \mathrm{mmol}$, commercially available as the Nitro-Grela catalyst) were charged under a stream of $\mathrm{N}_{2}$, the system was sealed. The resulting mixture was aged $(1 \mathrm{~h})$ at $40{ }^{\circ} \mathrm{C}$, deemed complete by ${ }^{1} \mathrm{H}$ NMR, and hexanes $(15.00 \mathrm{ml})$ was slowly charged at $40{ }^{\circ} \mathrm{C}$ over 30 minutes. The resulting slurry was then allowed to cool to RT, filtered through a sintered funnel, washed in 2 portions with $25 \%$ toluene in hexane $(20.00 \mathrm{ml} ; 2 \times 10 \mathrm{~mL})$, and then washed with 4 portions of hexanes $(40.0 \mathrm{ml} ; 4 \times 10 \mathrm{~mL})$. The resulting wet cake was dried in a vacuum oven to yield the desired product $9 \mathbf{e}\left(900 \mathrm{mg}, 80 \%\right.$ yield) as a reddish solid. ${ }^{\mathbf{1}} \mathbf{H}$ NMR $\left(400 \mathrm{MHz}, \mathrm{CD}_{2} \mathrm{Cl}_{2}\right): \delta 18.34(\mathrm{t}, J=4.5 \mathrm{~Hz}, 1 \mathrm{H}), 7.37-6.96(\mathrm{~m}, 6 \mathrm{H}), 6.78(\mathrm{dd}, J=9.2,2.9 \mathrm{~Hz}$, $1 \mathrm{H}), 4.13(\mathrm{ddd}, J=14.3,8.9,3.5 \mathrm{~Hz}, 5 \mathrm{H}), 3.93(\mathrm{~s}, 3 \mathrm{H}), 3.29-3.16(\mathrm{~m}, 2 \mathrm{H}), 2.80$ (ddd, $J=7.9$, 6.3, $4.6 \mathrm{~Hz}, 2 \mathrm{H}), 2.73-2.25(\mathrm{~m}, 18 \mathrm{H}), 1.52-1.35(\mathrm{~m}, 6 \mathrm{H}) ;{ }^{13} \mathbf{C}-\mathbf{N M R}\left(100 \mathrm{MHz}, \mathrm{CD}_{2} \mathrm{Cl}_{2}\right): \delta$ 215.2, 160.0, 156.6, 152.8, 143.0, 140.5, 140.3 (br), 138.8 (br), 138.5 (br), 137.4 (br), 137.2 (br), 135.3 (br), 135.1 (br), 134.4, 130.3, 129.9, 129.6, 129.5, 129.3, 129.0, 128.2, 126.9, 126.2, 125.2, 119.6, 106.4, 55.8, 52.1, 51.7 (br), 50.9 (br), 35.6, 27.9, 22.4, 21.2 (br), 20.9 (br), 20.0 (br), 18.0 (br). ESI-HRMS (m/z): Calc'd for $\mathrm{C}_{36} \mathrm{H}_{45} \mathrm{Cl}_{2} \mathrm{~N}_{4} \mathrm{ORuS}(\mathrm{M}+\mathrm{H})$ : 753.1735; Found: 753.1628.

\section{Complex 9f}
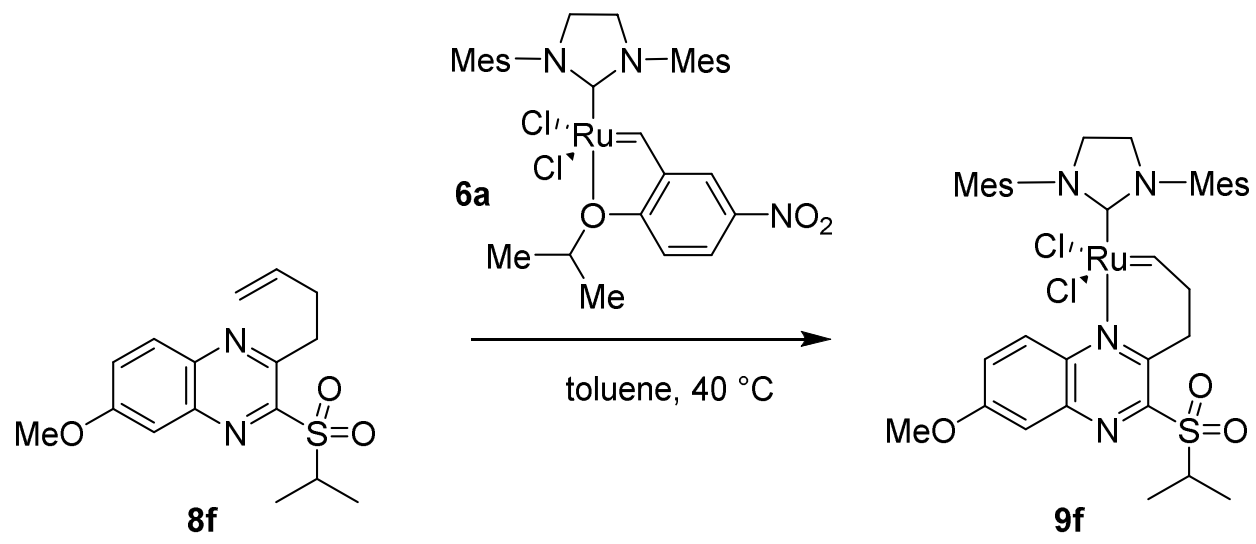
To a round-bottom flask was charged 2-(but-3-en-1-yl)-3-(isopropylsulfonyl)-6methoxyquinoxaline (8f) (1.19 g, 3.72 mmol, 1.5 equiv.), and the system was purged with $\mathrm{N}_{2}$. Toluene $(10.00 \mathrm{ml})$ was charged to the system under inert handling; precatalyst $6 \mathbf{6}(1.00 \mathrm{~g}, 1.49$ mmol, commercially available as the Nitro-Grela catalyst) was charged under a stream of $\mathrm{N}_{2}$; the system was sealed. The system was aged at $40{ }^{\circ} \mathrm{C}$ over 1 hour. Then hexanes $(11.70 \mathrm{~mL})$ was slowly added to the reaction at $40{ }^{\circ} \mathrm{C}$ over 30 minutes. The resulting mixture was allowed to age for approximately $1 \mathrm{~h}$ at RT, then filtered through a sintered funnel, washed in two portions with $25 \%$ toluene in hexanes $(20.00 \mathrm{ml} ; 2 \times 10 \mathrm{~mL})$, and in four portions with hexanes $(40.0 \mathrm{ml} ; 4 \mathrm{x}$ $10 \mathrm{~mL}$ ). The resulting wet cake was dried on the filter with vacuum and $\mathrm{N}_{2}$ purge to yield the desired product (9f) (1.00 g, 85\% yield). ${ }^{1} \mathbf{H}$ NMR (400 MHz, $\left.\mathrm{CD}_{2} \mathrm{Cl}_{2}\right): \delta 18.24(\mathrm{t}, J=4.0 \mathrm{~Hz}$, $1 \mathrm{H}), 7.26(\mathrm{~d}, J=2.8 \mathrm{~Hz}, 1 \mathrm{H}), 7.25-7.16(\mathrm{~m}, 3 \mathrm{H}), 7.16-6.96(\mathrm{~m}, 3 \mathrm{H}), 5.37(\mathrm{~s}, 1 \mathrm{H}), 4.30$ (hept, $J=6.9 \mathrm{~Hz}, 1 \mathrm{H}), 4.14(\mathrm{~d}, J=7.7 \mathrm{~Hz}, 4 \mathrm{H}), 3.97(\mathrm{~s}, 3 \mathrm{H}), 3.96-3.90(\mathrm{~m}, 2 \mathrm{H}), 2.67-2.14(\mathrm{~m}$, 18H), $1.45(\mathrm{~d}, J=6.9 \mathrm{~Hz}, 6 \mathrm{H}) .{ }^{13} \mathbf{C}-\mathbf{N M R}\left(100 \mathrm{MHz}, \mathrm{CD}_{2} \mathrm{Cl}_{2}\right): \delta 213.5,161.0,152.8,151.1$, 140.8, 140.5 (br), 139.1, 138.8 (br), 138.7 (br), 137.3 (br), 136.9 (br), 135.2, 135.0 (br), 129.9, 129.5, 126.6, 125.3, 107.0, 56.1, 53.97, 53.90, 53.1, 51.8, 51.6, 50.9, 28.2, 21.1 (br), 20.9 (br), 20.1 (br), 18.0 (br), 15.3. ESI-HRMS (m/z): Calc'd for $\mathrm{C}_{36} \mathrm{H}_{45} \mathrm{Cl}_{2} \mathrm{~N}_{4} \mathrm{O}_{3} \mathrm{RuS}(\mathrm{M}+\mathrm{H})$ : 785.1633; Found: 785.1565.

\section{Complex 9g (Procedure A)}

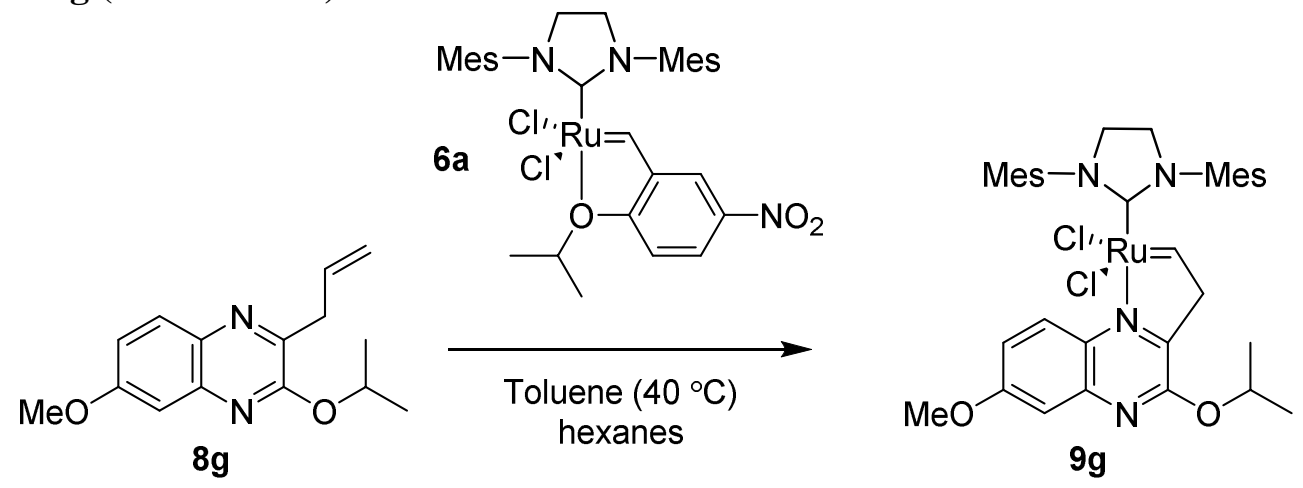

To a Schlenk flask was charged 2-allyl-3-isopropoxy-6-methoxyquinoxaline (8g) (0.865 g, 3.35 mmol, 2.25 equiv.) and toluene $(5 \mathrm{~mL})$. The system was degassed. Pre-catalyst 6a (1.00 g, 1.49 mmol, commercially available as the Nitro-Grela catalyst) was charged under a stream of $\mathrm{N}_{2}$, and the system was sealed. The mixture was heated and aged $(2.5 \mathrm{~h})$ at $40^{\circ} \mathrm{C}$. The mixture was deemed complete by ${ }^{1} \mathrm{H}$ NMR analysis and the mixture allowed to cool to room temperature. MTBE (5 mL) was slowly added, allowed to stir, and then filtered through a sintered funnel at RT. The wet cake was washed with additional MTBE $(3 \times 5 \mathrm{~mL}$; slurry, slurry, displacement washes), and then dried in a vacuum oven with a slow nitrogen bleed at room temperature to yield the toluene hemi-solvate of the desired product $(9 \mathrm{~g})(1.04 \mathrm{~g}, 91 \%$ yield) as a dark orange solid. ${ }^{1} \mathbf{H}$ NMR $\left(500 \mathrm{MHz}, \mathrm{CD}_{2} \mathrm{Cl}_{2}\right) \delta 17.06(\mathrm{t}, J=2.7 \mathrm{~Hz}, 1 \mathrm{H}), 7.28-7.14(\mathrm{~m}, 2.5 \mathrm{H}$ - toluene), $7.14-7.04(\mathrm{~m}, 6 \mathrm{H}), 6.91$ (dd, $J=9.1,2.7 \mathrm{~Hz}, 1 \mathrm{H}), 5.47$ (hept, $J=6.2 \mathrm{~Hz}, 1 \mathrm{H}), 4.15$ (s, 4H), $3.90(\mathrm{~s}, 3 \mathrm{H}), 2.85(\mathrm{~d}, J=2.7 \mathrm{~Hz}, 2 \mathrm{H}), 2.47-2.48(\mathrm{~m}, 18 \mathrm{H}), 2.35(\mathrm{~d}, J=0.7 \mathrm{~Hz}, 2 \mathrm{H}), 1.38(\mathrm{~d}, J=$ $6.2 \mathrm{~Hz}, 6 \mathrm{H}) .{ }^{13} \mathrm{C}-\mathrm{NMR}\left(125 \mathrm{MHz}, \mathrm{CD}_{2} \mathrm{Cl}_{2}\right.$ ): $\delta$ 215.4, 161.3, 155.0, 147.9, 143.5, 139.6 (br), 
139.3, 138.5 (toluene), 133.0, 129.8, 129.5 (toluene), 128.7 (toluene), 126.7, 125.8 (toluene), 118.3, 106.8, 70.3, 67.5, 56.3, 52.1, 22.2, 21.6 (toluene), 21.5, 19.8 (br). ESI-HRMS (m/z): Calc'd for $\mathrm{C}_{35} \mathrm{H}_{43} \mathrm{Cl}_{2} \mathrm{~N}_{4} \mathrm{O}_{2} \mathrm{Ru}(\mathrm{M}+\mathrm{H})$ : 723.1801; Found: 723.1768 .

\section{Complex 9g (Procedure B)}
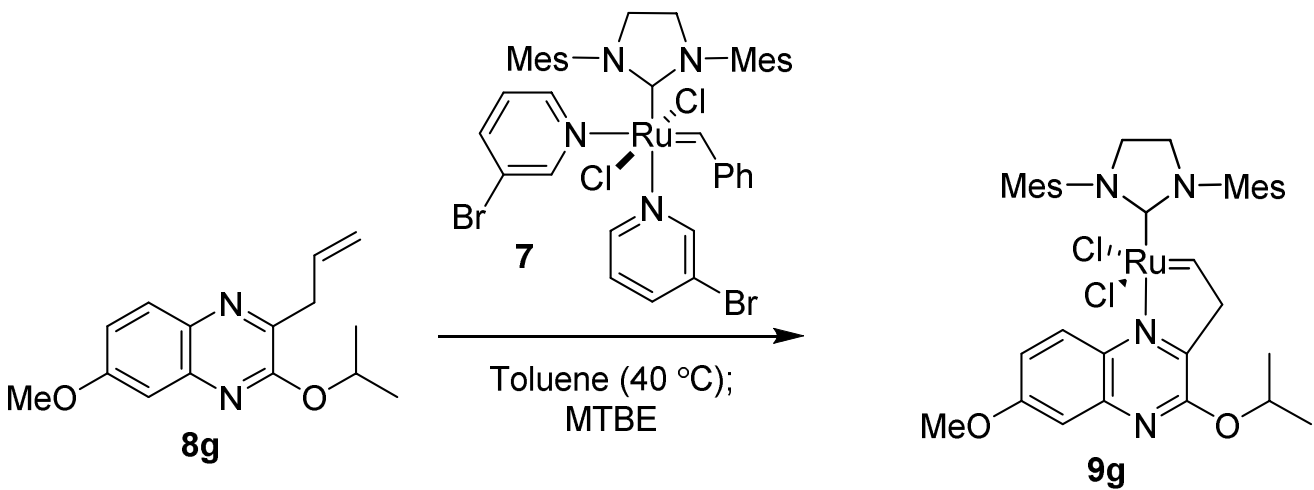

To a $10 \mathrm{~mL}$ schlenk flask was charged precatalyst $7(700 \mathrm{mg}, 0.791 \mathrm{mmol}$, ) and then sealed. A solution of 2-allyl-3-isopropoxy-6-methoxyquinoxaline (8g) (460 mg, $1.781 \mathrm{mmol}, 2.25$ equiv.) in Toluene ( $2.80 \mathrm{ml}, 4$ volumes) was then charged under $\mathrm{N}_{2}$. The system was stirred and heated to $40{ }^{\circ} \mathrm{C}$ whereupon it deemed complete via ${ }^{1} \mathrm{H}$ NMR analysis (1h). The reaction mixture was allowed to cool to room temperature where it was then treated with MTBE $(2.80 \mathrm{~mL}, 4$ volumes), allowed to age at room temperature ( 15 minutes) and the system was then filtered to yield an orange solid which was further washed with MTBE $(2 \times 2.8 \mathrm{~mL})$. The result wet slurry was then dried in a vacuum oven with a slow nitrogen bleed at room temperature to yield the toluene hemi-solvate of the desired product $(\mathbf{9 g})(470 \mathrm{mg}, 77 \%$ yield) as a dark orange solid. The characterization data matched that of the Procedure A provided above. Note: The material prepared from this procedure $(\mathbf{9 g})$ was utilized in all the kinetic studies and reactions for this publication.

\section{Crystal Data and Structure Refinement for Complex 9a (CCDC 1444069)}

A single crystal of Complex 9a grown from dichloromethane and hexane by solvent evaporation was selected for single crystal X-ray data analysis. The crystal was a small red plate with dimensions of $0.20 \mathrm{~mm} \times 0.20 \mathrm{~mm}$ x $0.05 \mathrm{~mm}$. Data collection was performed on a Bruker Apex II system at $100 \mathrm{~K}$. The unit cell was determined to be monoclinic in space group $\mathrm{P} 2{ }_{1} / n$. The structure contained one molecule in the crystallographic asymmetric unit. Crystallographic data is summarized in Table S1. Figure S1 shows an ORTEP representation of Complex 9a with thermal ellipsoids set at the $50 \%$ probability level. Coordinates, refinement details and structure factors have been deposited with the Cambridge Crystallographic Data Centre (CCDC 1444069). 
Figure S1: ORTEP representation of Complex 9a with thermal ellipsoids set at the 50\% probability level.

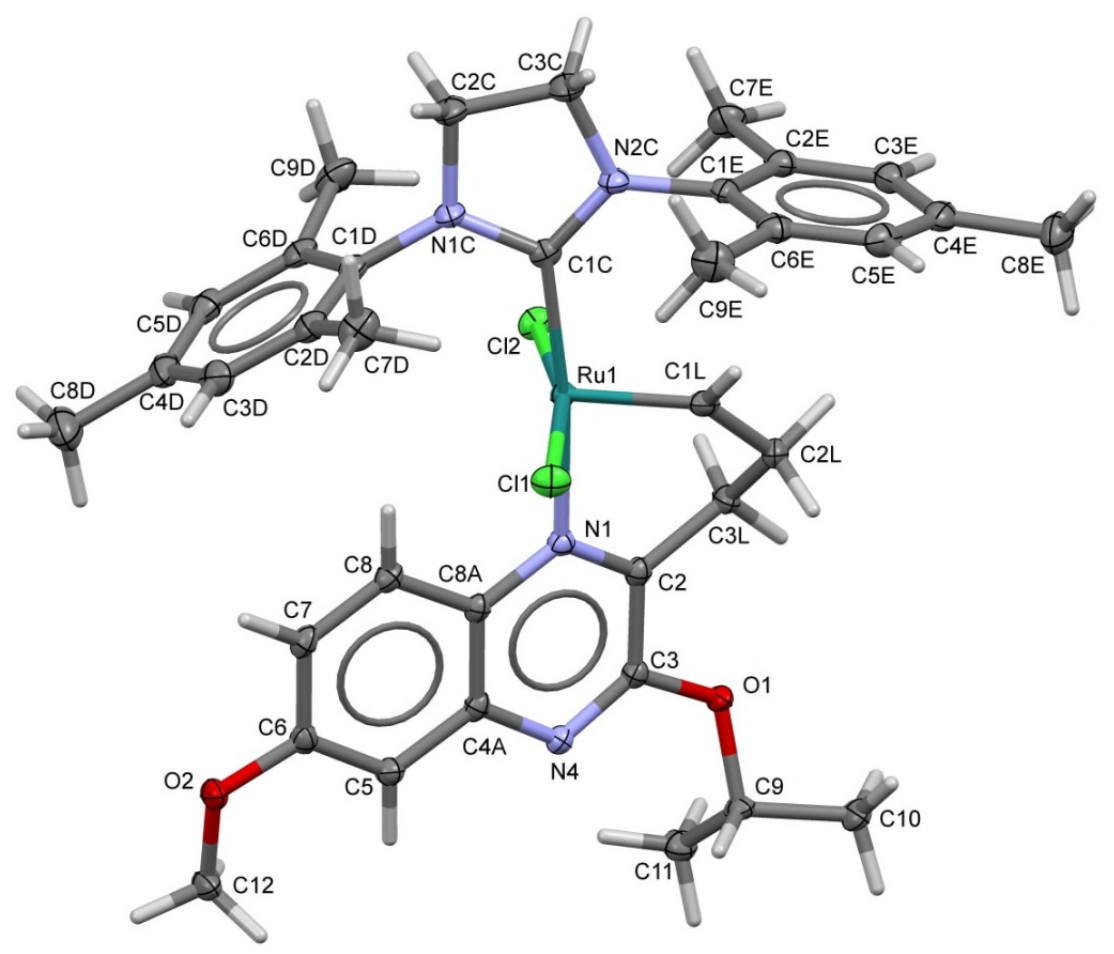

Table S1. Crystal Data and Structure Refinement for Complex 9a [CCDC 1444069]

Identification code

Empirical formula

Formula weight

Temperature

Wavelength

Crystal system

Space group

Unit cell dimensions

Volume

Z

Density (calculated)

Absorption coefficient mdk001

$\mathrm{C}_{36} \mathrm{H}_{44} \mathrm{C}_{12} \mathrm{~N}_{4} \mathrm{O}_{2} \mathrm{Ru}$

736.72

100(2) K

$1.54178 \AA$

Monoclinic

$\mathrm{P} 2{ }_{1} / n$

$a=11.9275(8) \AA \quad \alpha=90^{\circ}$

$\mathrm{b}=15.7557(10) \AA \quad \beta=97.6486(17)^{\circ}$.

$\mathrm{c}=18.3669(12) \AA \quad \gamma=90^{\circ}$.

3420.9(4) $\AA^{3}$

4

$1.430 \mathrm{Mg} / \mathrm{m}^{3}$

$5.442 \mathrm{~mm}^{-1}$ 
Crystal size

Theta range for data collection

Index ranges

Reflections collected

Independent reflections

Completeness to theta $=66.500^{\circ}$

Absorption correction

Max. and min. transmission

Refinement method

Data / restraints / parameters

Goodness-of-fit on $\mathrm{F}^{2}$

Final $\mathrm{R}$ indices [I>2sigma(I)]

$\mathrm{R}$ indices (all data)

Largest diff. peak and hole
$0.200 \times 0.200 \times 0.050 \mathrm{~mm}^{3}$

3.710 to $66.716^{\circ}$.

$-14<=\mathrm{h}<=12,-18<=\mathrm{k}<=18,-21<=\mathrm{l}<=20$

23191

$6031[\mathrm{R}(\mathrm{int})=0.0255]$

$99.7 \%$

Semi-empirical from equivalents

0.762 and 0.533

Full-matrix least-squares on $\mathrm{F}^{2}$

$6031 / 0 / 415$

1.057

$\mathrm{R} 1=0.0211, \mathrm{wR} 2=0.0534$

$\mathrm{R} 1=0.0216, \mathrm{wR} 2=0.0536$

0.359 and -0.396 e. $\AA^{-3}$

\section{Experimental Procedure for Discovery of Quinoxaline-Based Complex 5}

To a 2 dram vial was charged (2S,4R)-1-tert-butyl 2-methyl 4-((3-(but-3-en-1-yl)-7methoxyquinoxalin-2-yl)oxy)pyrrolidine-1,2-dicarboxylate (3) (133 mg, $0.212 \mathrm{mmol}, 1$ equiv) dichloromethane $(12.00 \mathrm{ml})$, and then Hoveyda-Grubbs $2^{\text {nd }}$ generation precatalyst $(4)$ (133 mg, 0.212 mmol, 1 equiv) was then charged to the mixture as a solid under a stream of $\mathrm{N}_{2}$. Then charged deuterated chloroform (4 mL). The reaction was monitored by ${ }^{1} \mathrm{H}$ NMR. 
Reference 1H-NMR of Hoveyda-Grubbs-2G (4)

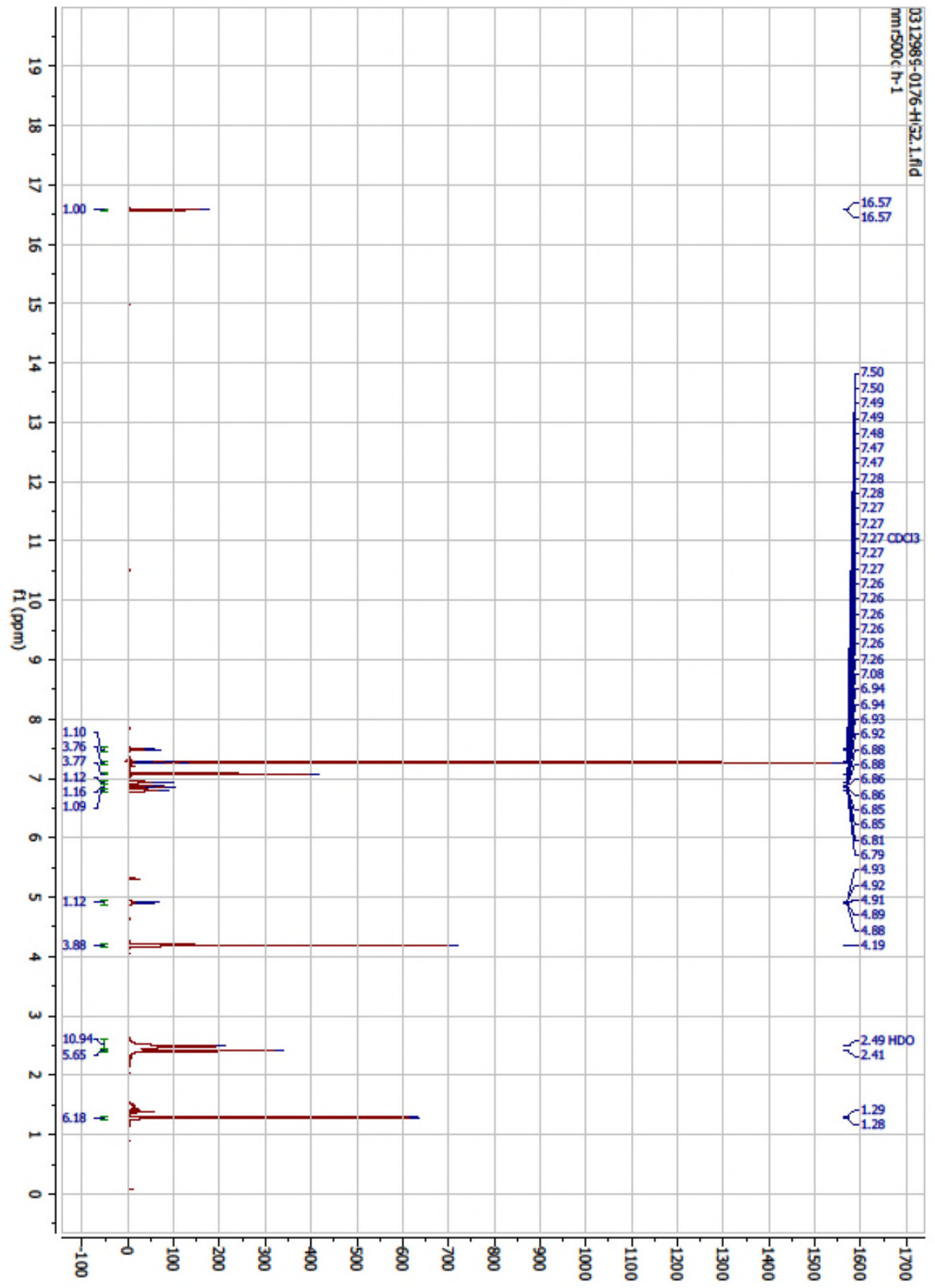


1H-NMR of compound 3

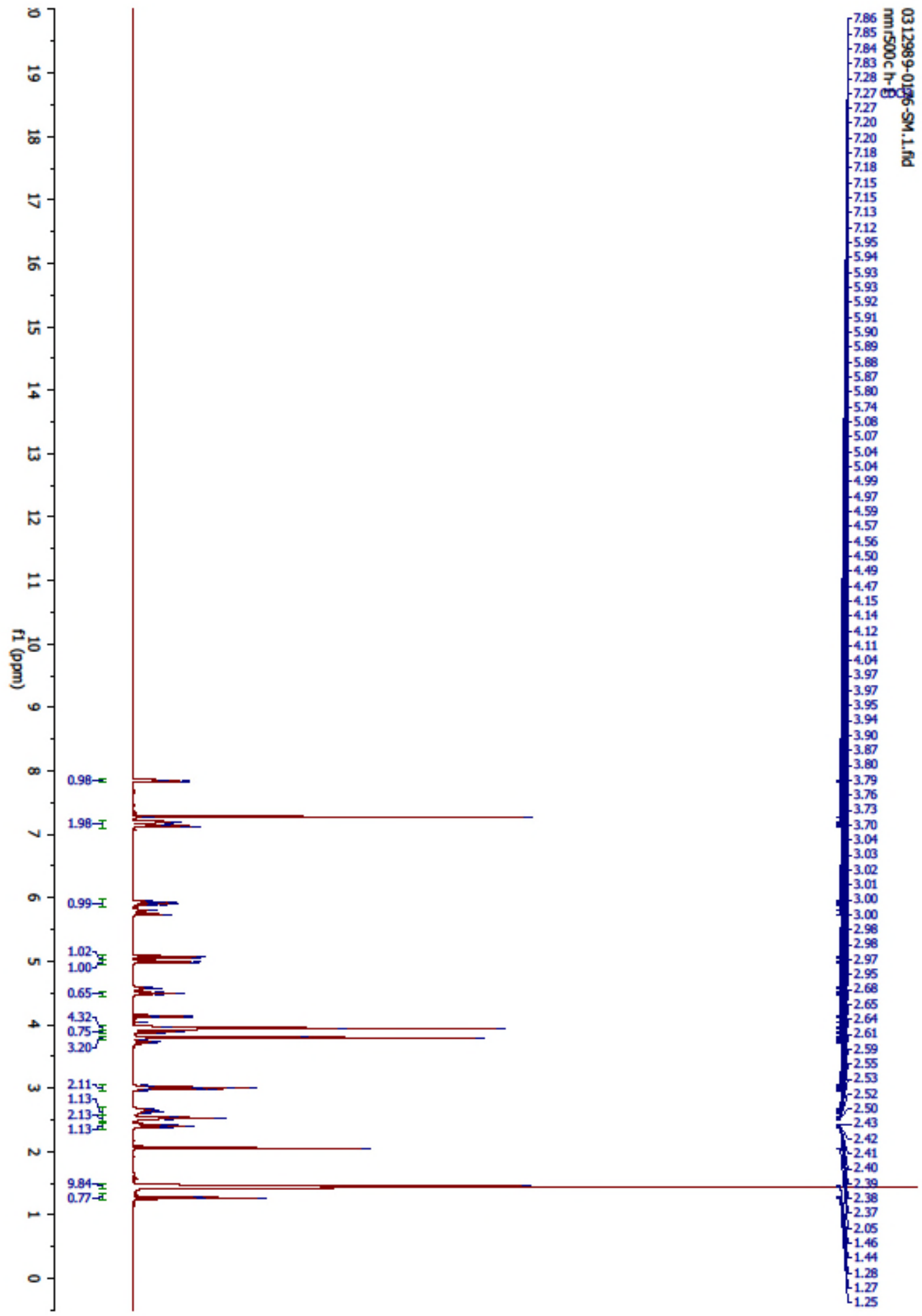


1H-NMR of the Reaction after 1.5 hour

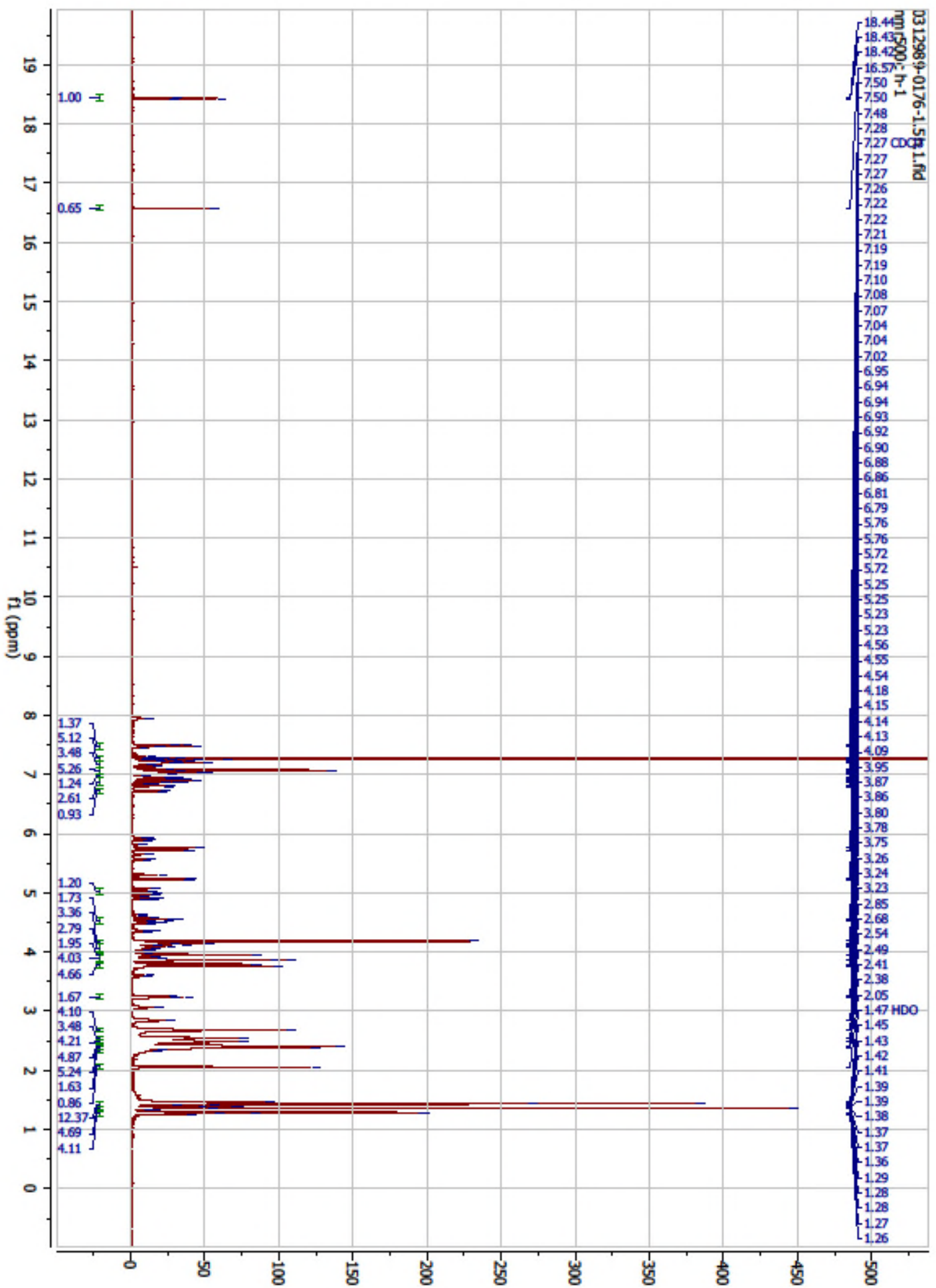


1H-NMR of the Reaction after 3.5 hour

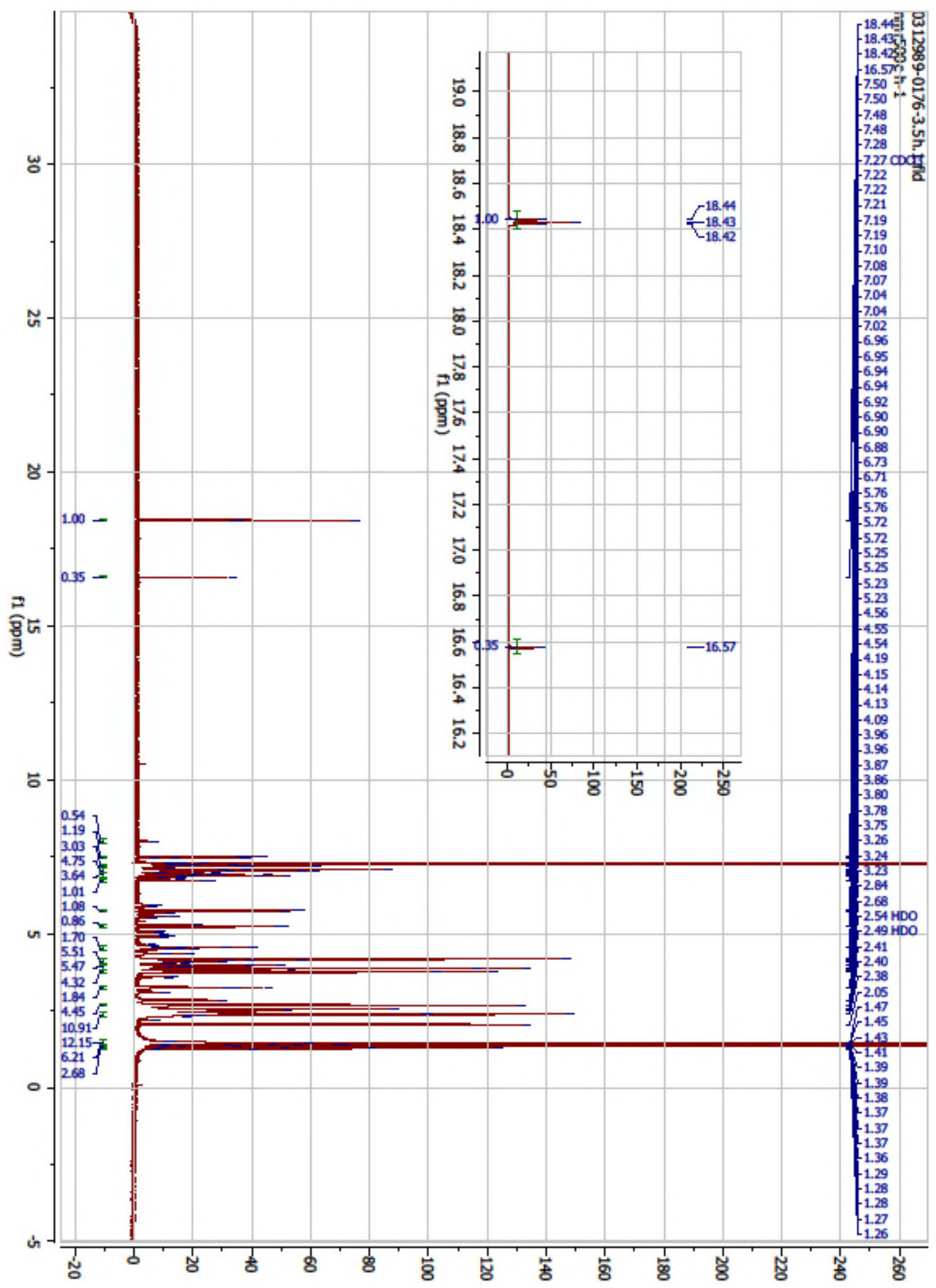


1H-NMR of the Reaction after overnight

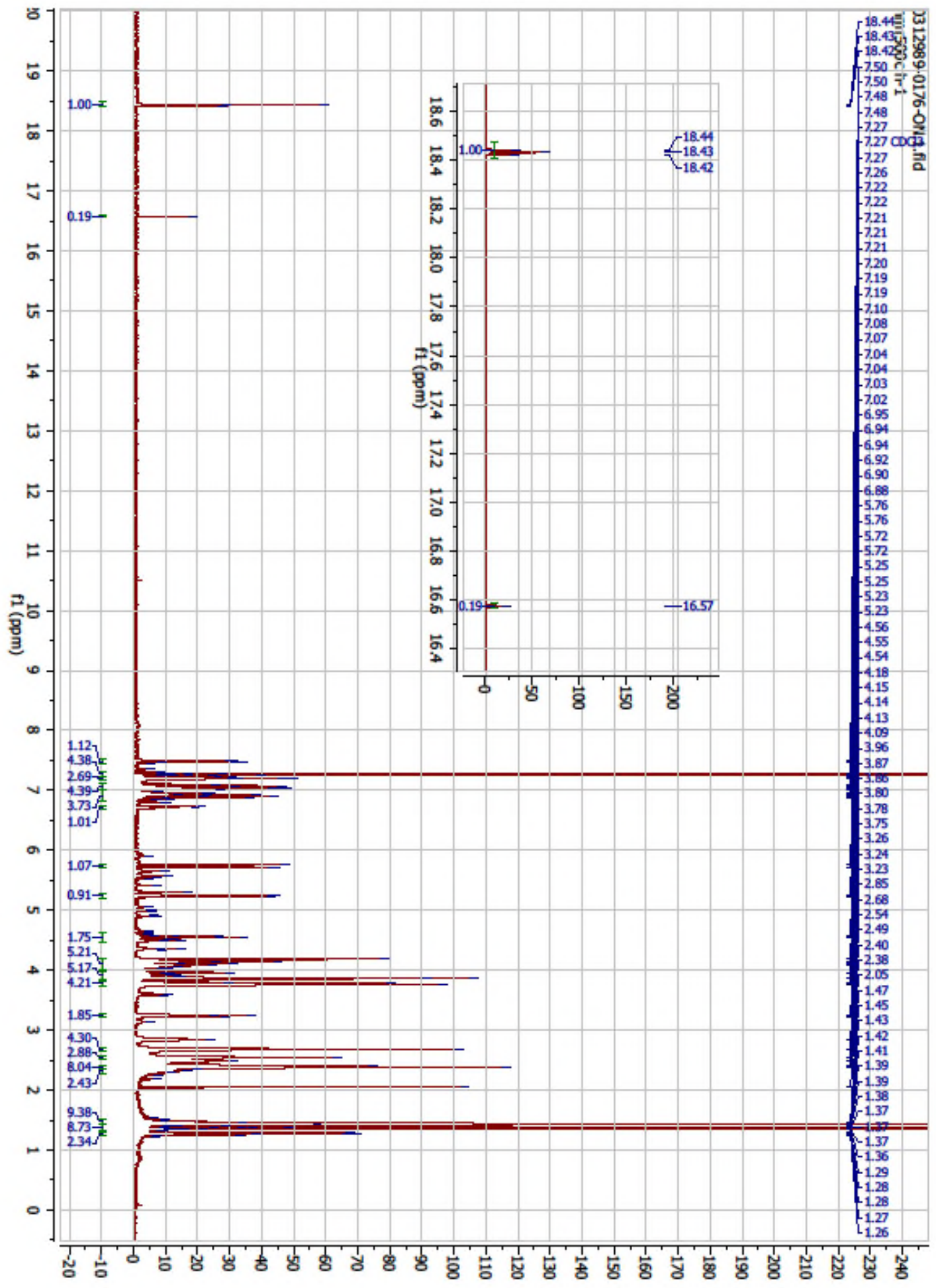




\section{Experimental Procedures for Solution Stability Study of Complex 9a}

\section{Solution Stability}

In a glovebox, anthracene (27.6 mg, 99.9\% purity) was dissolved in $\mathrm{CD}_{2} \mathrm{Cl}_{2}$ ( $3 \mathrm{~mL}$ volumetric flask). In a separated $4 \mathrm{~mL}$ vial was weighed out complex $9 \mathrm{a}(50 \mathrm{mg}, 0.068 \mathrm{mmol})$. To the vial containing the complex 9a was charged the anthracene solution in $\mathrm{CD}_{2} \mathrm{Cl}_{2}(650 \mu \mathrm{L}, 6.0 \mathrm{mg}$, 0.034 mmol, 0.05 equiv.) and the mixtures was stirred until the solids dissolved. The resulting dark solution was then placed into a J-young NMR tube and sealed under $\mathrm{N}_{2}$. The NMR tube was removed from the glovebox, and aged at room temperature $\left(21-26{ }^{\circ} \mathrm{C}\right)$ in the absence of light. An initial ${ }^{1} \mathrm{H}$ NMR was obtained and then another ${ }^{1} \mathrm{H}$ NMR was obtained after 30 days. No decomposition was observed (Figure $\mathbf{S 2}$ and $\mathbf{S 3}$ ).

\section{Solid Stability:}

The general purity and stability of solids was obtained by ${ }^{1} \mathrm{H}$ NMR measurements using high purity1,3,5-trimethoxybenzene as an external standard. Typically $\mathrm{CD}_{2} \mathrm{Cl}_{2}$ was utilized as the ${ }^{1} \mathrm{H}$ NMR solvent. During the course of production, no decomposition was observed after measuring the wt\% purity of the solid complex (9a) after being stored in an amber bottle at room temperature in a desiccator for approximately 6 months.

Figure S2: Complex 9a stability study ${ }^{1} \mathrm{H}$ NMR $\left(\mathrm{CD}_{2} \mathrm{Cl}_{2}\right)$ - Initial NMR

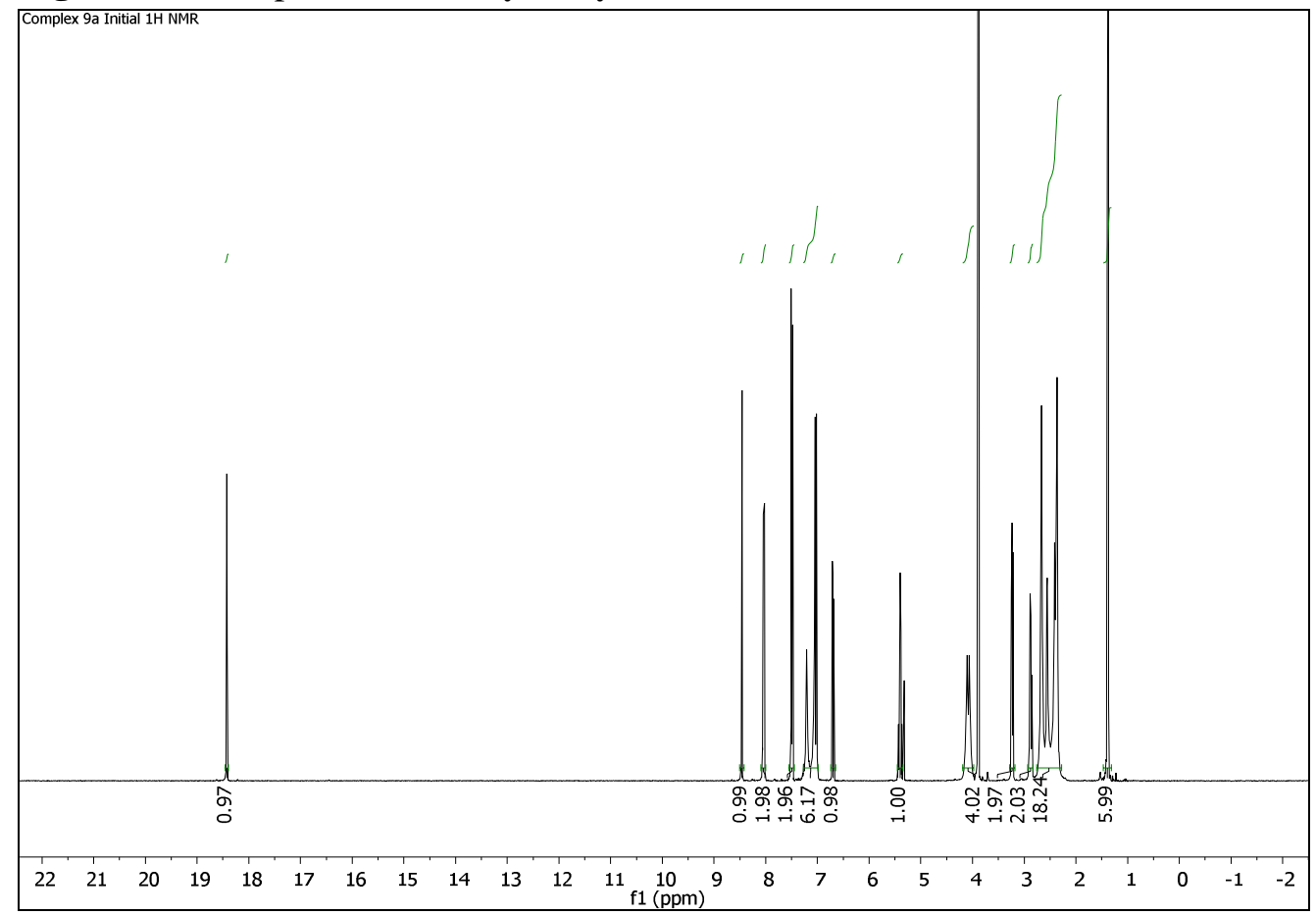


Figure S3: Complex 9a stability study ${ }^{1} \mathrm{H}$ NMR $\left(\mathrm{CD}_{2} \mathrm{Cl}_{2}\right)-$ After 30 days

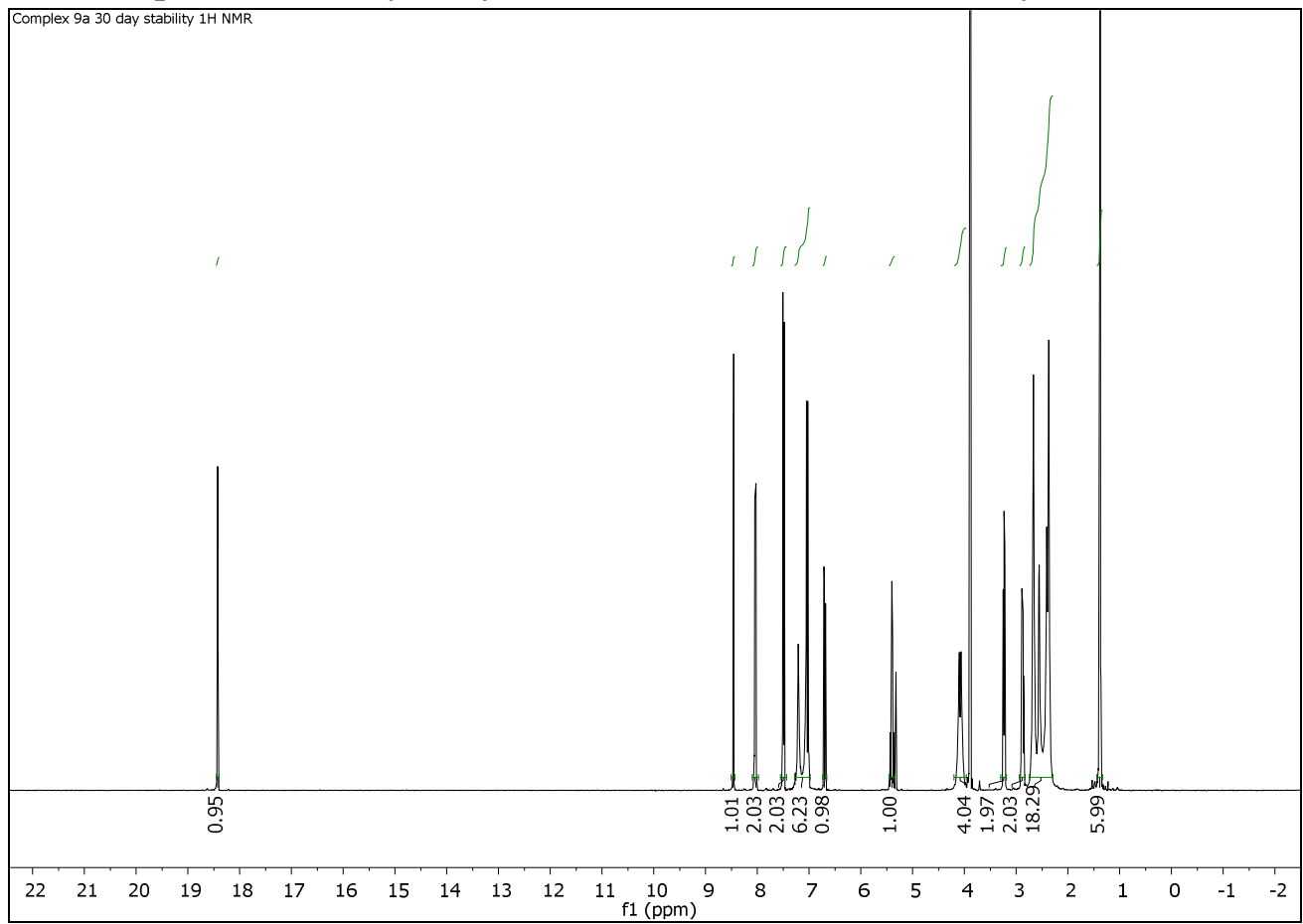

\section{Experimental Procedures for Figure $2^{9}$}

\section{General Procedure}

In a glovebox, to a 2-mL volumetric flask with screw-top septum was charged the ruthenium complex described $(0.0325 \mathrm{mmol})$. The system was diluted with $\mathrm{CD}_{2} \mathrm{Cl}_{2}(0.016 \mathrm{M})$ to the appropriate volume marker and then sealed. To an NMR tube with screw cap septum, in a glovebox, was charged $\mathrm{CD}_{2} \mathrm{Cl}_{2}(0.75 \mathrm{~mL})$. Subsequently, the ruthenium complex solution (50 $\mu \mathrm{L}, 0.8 \mu \mathrm{mol}, 1 \mathrm{~mol} \%$ ) was then charged via $50 \mu \mathrm{L}$ syringe to the NMR tube, sealed, and taken out of the glovebox. The NMR tube was then placed in the NMR and the system was equilibrated to $303 \mathrm{~K}$ for $\sim 10-15$ minutes. The NMR sample was locked, tuned, and then shimmed. The sample was ejected, tert-butyl diallylcarbamate $(\mathbf{1 0})(18 \mu \mathrm{L}, 0.083 \mathrm{mmol}, 0.1 \mathrm{M})$ was charged via $25 \mu \mathrm{L}$ syringe, and the mixed sample was placed back into the NMR where conversion was measured ${ }^{1} \mathrm{H}$ NMR scans approximately every 1 minute. ${ }^{9}$ The data can be seen below.

\footnotetext{
${ }^{9}$ See the following for a catalyst characterization and comparator technique that was utilized to obtain the ruthenium complex kinetic profiles: Ritter,T.; Hejl, A.; Wenzel, A. G.; Funk, T. W.; Grubbs, R. H. Organometallics 2006, 25, 5740-5745.
} 


\section{Conversion Table for Figure 2}

RCM of tert-butyl diallylcarbamate 10 with complexes $9 \mathrm{a}, 9 \mathbf{9 c}, 9 \mathbf{9}$ and $9 \mathrm{~g}$

\begin{tabular}{|c|c|c|c|c|c|c|c|}
\hline \multicolumn{4}{|c|}{ Complex 9a data } & \multicolumn{4}{|c|}{ Complex 9c data } \\
\hline $\begin{array}{l}\text { Rxn Time } \\
\text { (min) }\end{array}$ & $\begin{array}{l}\text { Product } \\
\text { Int }\end{array}$ & SM Int & Conv. (\%) & $\begin{array}{l}\text { Rxn Time } \\
\text { (min) }\end{array}$ & $\begin{array}{l}\text { Product } \\
\text { Int }\end{array}$ & SM Int & Conv. (\%) \\
\hline 0.0 & 0 & 100 & $0 \%$ & 0.0 & 0 & 100 & $0 \%$ \\
\hline 1.0 & 1.68662 & 98.3134 & $2 \%$ & 1.1 & 1.67069 & 98.3293 & $2 \%$ \\
\hline 2.2 & 4.12398 & 94.9057 & $4 \%$ & 2.2 & 3.0165 & 96.333 & $3 \%$ \\
\hline 3.3 & 8.88972 & 89.9743 & $9 \%$ & 3.3 & 4.53929 & 94.8626 & $5 \%$ \\
\hline 4.4 & 15.3762 & 83.3304 & $16 \%$ & 4.5 & 7.43786 & 91.8685 & $7 \%$ \\
\hline 5.6 & 22.7334 & 78.2245 & $23 \%$ & 5.7 & 10.9828 & 88.227 & $11 \%$ \\
\hline 6.7 & 29.5033 & 71.1775 & $29 \%$ & 6.8 & 15.5549 & 83.6033 & $16 \%$ \\
\hline 7.8 & 34.9331 & 65.8164 & $35 \%$ & 7.9 & 20.0794 & 79.0801 & $20 \%$ \\
\hline 8.9 & 39.962 & 60.4811 & $40 \%$ & 9.0 & 24.6513 & 74.5479 & $25 \%$ \\
\hline 10.0 & 44.4192 & 56.0573 & $44 \%$ & 10.1 & 28.7582 & 70.3401 & $29 \%$ \\
\hline 11.2 & 48.4441 & 51.7929 & $48 \%$ & 11.2 & 32.8975 & 66.204 & $33 \%$ \\
\hline 12.3 & 51.846 & 48.6621 & $52 \%$ & 12.3 & 36.4058 & 62.5479 & $37 \%$ \\
\hline 13.4 & 55.2007 & 45.0258 & $55 \%$ & 13.5 & 39.8392 & 59.2362 & $40 \%$ \\
\hline 14.6 & 58.1278 & 42.0076 & $58 \%$ & 14.6 & 42.8172 & 56.0528 & $43 \%$ \\
\hline 15.8 & 60.7823 & 39.4185 & $61 \%$ & 15.7 & 45.551 & 53.327 & $46 \%$ \\
\hline 16.9 & 63.0489 & 36.9925 & $63 \%$ & 16.8 & 48.079 & 50.8944 & $49 \%$ \\
\hline 18.0 & 65.0548 & 35.0266 & $65 \%$ & 17.9 & 50.4944 & 48.4187 & $51 \%$ \\
\hline 19.1 & 67.048 & 33.0528 & $67 \%$ & 19.0 & 52.5806 & 46.3028 & $53 \%$ \\
\hline 20.2 & 68.7674 & 31.0646 & $69 \%$ & 20.1 & 54.6114 & 44.3062 & $55 \%$ \\
\hline 21.4 & 70.3137 & 29.5925 & $70 \%$ & 21.2 & 56.5528 & 42.2163 & $57 \%$ \\
\hline 22.5 & 71.71 & 28.168 & $72 \%$ & 22.4 & 58.3509 & 40.2898 & $59 \%$ \\
\hline 23.6 & 73.0542 & 26.9145 & $73 \%$ & 23.5 & 59.9926 & 38.4796 & $61 \%$ \\
\hline 24.7 & 74.2042 & 25.775 & $74 \%$ & 24.7 & 61.7442 & 36.8178 & $63 \%$ \\
\hline 25.8 & 75.3473 & 24.4149 & $76 \%$ & 25.8 & 63.21 & 35.3659 & $64 \%$ \\
\hline 27.0 & 76.3827 & 23.42 & $77 \%$ & 27.0 & 64.4834 & 34.045 & $65 \%$ \\
\hline 28.1 & 77.4026 & 22.5217 & $77 \%$ & 28.1 & 65.7236 & 32.9489 & $67 \%$ \\
\hline 29.3 & 78.3222 & 21.4328 & $79 \%$ & 29.3 & 67.0029 & 31.5431 & $68 \%$ \\
\hline 30.5 & 79.1463 & 20.59 & $79 \%$ & 30.5 & 68.0747 & 30.3419 & $69 \%$ \\
\hline \multicolumn{4}{|c|}{ Complex $9 f$ data } & \multicolumn{4}{|c|}{ Complex 9g data } \\
\hline $\begin{array}{l}\text { Rxn Time } \\
\text { (min) }\end{array}$ & $\begin{array}{c}\text { Product } \\
\text { Int }\end{array}$ & SM Int & Conv. (\%) & $\begin{array}{l}\text { Rxn Time } \\
\text { (min) }\end{array}$ & $\begin{array}{l}\text { Product } \\
\text { Int }\end{array}$ & SM Int & Conv. (\%) \\
\hline 0.00 & 0 & 100 & $0 \%$ & 0.00 & 0 & 100 & $0.0 \%$ \\
\hline 1.13 & 9.55762 & 90.4424 & $10 \%$ & 1.07 & 0.209227 & 99.790773 & $0.2 \%$ \\
\hline 2.30 & 28.3847 & 70.7709 & $29 \%$ & 2.20 & 0.373543 & 98.3786 & $0.4 \%$ \\
\hline 3.40 & 42.1799 & 56.5764 & $43 \%$ & 3.37 & 0.491804 & 97.9064 & $0.5 \%$ \\
\hline 4.48 & 52.3946 & 46.2975 & $53 \%$ & 4.48 & 0.511241 & 97.9493 & $0.5 \%$ \\
\hline
\end{tabular}




\begin{tabular}{|cccc|cccc|}
5.60 & 60.2683 & 38.4629 & $61 \%$ & 5.67 & 0.55485 & 97.8993 & $0.6 \%$ \\
6.77 & 66.354 & 32.2157 & $67 \%$ & 6.83 & 0.563846 & 97.7651 & $0.6 \%$ \\
7.93 & 71.0504 & 27.3864 & $72 \%$ & 7.93 & 0.553172 & 97.5429 & $0.6 \%$ \\
9.03 & 74.4207 & 23.8536 & $76 \%$ & 9.05 & 0.609036 & 97.4232 & $0.6 \%$ \\
10.15 & 77.2509 & 21.1605 & $78 \%$ & 10.17 & 0.588657 & 97.5173 & $0.6 \%$ \\
11.27 & 79.4467 & 19.0182 & $81 \%$ & 11.28 & 0.5623 & 97.4907 & $0.6 \%$ \\
12.43 & 81.2867 & 16.726 & $83 \%$ & 12.47 & 0.568121 & 97.6685 & $0.6 \%$ \\
13.57 & 82.8365 & 15.1739 & $85 \%$ & 13.57 & 0.574393 & 97.823 & $0.6 \%$ \\
14.65 & 84.1026 & 13.8087 & $86 \%$ & 14.72 & 0.587702 & 98.127 & $0.6 \%$ \\
15.77 & 85.0106 & 12.6222 & $87 \%$ & 15.83 & 0.572307 & 98.1381 & $0.6 \%$ \\
16.87 & 86.126 & 11.7491 & $88 \%$ & 16.95 & 0.592879 & 97.9956 & $0.6 \%$ \\
17.98 & 87.0635 & 10.9901 & $89 \%$ & 18.13 & 0.566536 & 98.1386 & $0.6 \%$ \\
19.10 & 87.6842 & 10.2693 & $90 \%$ & 19.28 & 0.583352 & 98.1308 & $0.6 \%$ \\
20.20 & 88.1294 & 9.79746 & $90 \%$ & 20.45 & 0.59526 & 97.8626 & $0.6 \%$ \\
21.38 & 88.5557 & 8.93073 & $91 \%$ & 21.62 & 0.5647 & 97.6674 & $0.6 \%$ \\
22.57 & 89.0256 & 8.58622 & $91 \%$ & 22.78 & 0.542687 & 97.8955 & $0.6 \%$ \\
23.98 & 89.4474 & 7.98282 & $92 \%$ & 23.90 & 0.620397 & 97.5705 & $0.6 \%$ \\
25.15 & 89.7599 & 7.55357 & $92 \%$ & 24.98 & 0.586982 & 97.8534 & $0.6 \%$ \\
26.32 & 90.2424 & 7.29483 & $93 \%$ & 26.08 & 0.558267 & 98.1734 & $0.6 \%$ \\
27.47 & 90.5705 & 7.01371 & $93 \%$ & 27.18 & 0.591675 & 97.5133 & $0.6 \%$ \\
28.58 & 90.7569 & 6.93225 & $93 \%$ & 28.30 & 0.541654 & 98.1042 & $0.5 \%$ \\
29.70 & 91.1992 & 6.46975 & $93 \%$ & 29.47 & 0.59855 & 97.494 & $0.6 \%$ \\
30.85 & 91.4865 & 6.23461 & $94 \%$ & 30.65 & 0.625901 & 96.883 & $0.6 \%$ \\
\hline
\end{tabular}

\section{Experimental Procedures for Figure 3}

\section{General procedure without acid co-catalyst:}

In a glovebox, to a 2-mL volumetric flask with screw-top septum was charged the ruthenium complex $(0.0325 \mathrm{mmol})$. The system was diluted with $\mathrm{CD}_{2} \mathrm{Cl}_{2}(0.016 \mathrm{M})$ to the appropriate volume marker and then sealed. To an NMR tube with screw cap septum, in a glovebox, was charged $\mathrm{CD}_{2} \mathrm{Cl}_{2}(0.75 \mathrm{~mL})$. Subsequently, the ruthenium complex solution $(50 \mu \mathrm{L}, 0.8 \mu \mathrm{mol}, 1$ mol\%) was then charged to the NMR tube, sealed, and taken out of the glovebox. The NMR tube was then placed in the NMR and the system was equilibrated to $303 \mathrm{~K}$ for $\sim 10-15$ minutes. The NMR tube was locked, tuned, and then shimmed. The sample was ejected, 2,2diallylmalonate $(20 \mu \mathrm{L}, 83 \mu \mathrm{mol}, 0.1 \mathrm{M})$ was charged via $25 \mu \mathrm{L}$ syringe, and the mixed sample was placed back into the NMR where conversion was measured utilizing a macro to obtain ${ }^{1} \mathrm{H}$ NMR scans approximately every 1 minute. 


\section{General procedure with acid co-catalyst:}

In a glovebox, benzene sulfonic acid $(25 \mathrm{mg}, 0.16 \mathrm{mmol})$ was charged to a $2 \mathrm{~mL}$ volumetric flask and then diluted with $\mathrm{CD}_{2} \mathrm{Cl}_{2}(0.08 \mathrm{M})$. To an NMR tube with a screw top septum was charged $\mathrm{CD}_{2} \mathrm{Cl}_{2}(0.70 \mathrm{~mL})$ and then the benzene sulfonic acid solution prepared above was charged $(50 \mu \mathrm{L}, 3.95 \mu \mathrm{mol}, 5 \mathrm{~mol} \%)$. Diethyl 2,2-diallylmalonate (12) $(20 \mu \mathrm{L}, 83 \mu \mathrm{mol}, 0.1 \mathrm{M})$ was charged via $25 \mu \mathrm{L}$ syringe to the NMR tube, the solution was sealed, and then brought outside of the glove box. The NMR tube was then placed in the NMR, and the system was equilibrated to $303 \mathrm{~K}$ for approximately $10-15$ minutes, and the sample was locked, the probe was tuned, and then shimmed. The sample was then ejected, and the ruthenium pre-catalyst solution $(50 \mu \mathrm{L}, 0.8 \mu \mathrm{mol}, 1 \mathrm{~mol} \%, 0.001 \mathrm{M})$ was charged, under inert handling, and placed back into the NMR where the conversion was measured where conversion was measured to obtain ${ }^{1} \mathrm{H}$ NMR scans approximately every 1 minute. ${ }^{9}$

\section{Conversion Table for Figure 3}

RCM of diene 12 with catalysts $9 \mathrm{a}$ and $9 \mathrm{f}$ in the presence and absence benzenesulfonic acid $(5 \mathrm{~mol} \%)$

\begin{tabular}{|c|c|c|c|c|c|c|c|}
\hline & $\begin{array}{r}\text { Complex } \\
\text { B }\end{array}$ & a w/out & & & $\begin{array}{r}\text { Complex } \\
(5 \mathrm{~m}\end{array}$ & $\begin{array}{l}\text { a w/ BSA } \\
\mid \%)\end{array}$ & \\
\hline $\begin{array}{l}\text { Rxn } \\
\text { Time } \\
\text { (min) }\end{array}$ & $\begin{array}{l}\text { Product } \\
\text { Int }\end{array}$ & SM Int & $\begin{array}{c}\text { Conv. } \\
(\%)\end{array}$ & $\begin{array}{l}\text { Rxn } \\
\text { Time } \\
\text { (min) }\end{array}$ & $\begin{array}{l}\text { Product } \\
\text { Int }\end{array}$ & SM Int & $\begin{array}{c}\text { Conv. } \\
(\%)\end{array}$ \\
\hline 0.0 & 0 & 100 & $0 \%$ & 0.0 & 0 & 100 & $0 \%$ \\
\hline 1.0 & 3.25923 & 96.1501 & $3 \%$ & 1.2 & 61.0817 & 39.4233 & $61 \%$ \\
\hline 2.1 & 8.14875 & 90.9048 & $8 \%$ & 2.4 & 79.1996 & 20.3788 & $80 \%$ \\
\hline 3.3 & 13.2346 & 85.6957 & $13 \%$ & 3.5 & 85.8637 & 13.5678 & $86 \%$ \\
\hline 4.4 & 18.2057 & 80.5365 & $18 \%$ & 4.7 & 89.504 & 9.92667 & $90 \%$ \\
\hline 5.6 & 22.8319 & 75.8501 & $23 \%$ & 5.9 & 91.5772 & 7.64519 & $92 \%$ \\
\hline 6.8 & 27.0015 & 71.5535 & $27 \%$ & 7.1 & 92.9819 & 6.36688 & $94 \%$ \\
\hline 8.0 & 30.8594 & 67.5704 & $31 \%$ & 8.3 & 93.9336 & 5.44472 & $95 \%$ \\
\hline 9.2 & 34.4667 & 63.8662 & $35 \%$ & 9.5 & 94.616 & 4.7609 & $95 \%$ \\
\hline 10.4 & 37.6541 & 60.6798 & $38 \%$ & 10.7 & 95.0335 & 4.35166 & $95 \%$ \\
\hline 11.5 & 40.555 & 57.6842 & $41 \%$ & 11.9 & 95.4822 & 3.9432 & $96 \%$ \\
\hline 12.6 & 43.2144 & 55.0133 & $44 \%$ & 13.0 & 95.8137 & 3.70256 & $96 \%$ \\
\hline 13.8 & 45.8111 & 52.3233 & $47 \%$ & 14.2 & 95.9841 & 3.51712 & $96 \%$ \\
\hline 15.0 & 48.1825 & 49.8499 & $49 \%$ & 15.4 & 96.2242 & 3.30426 & $97 \%$ \\
\hline 16.2 & 50.4422 & 47.5186 & $51 \%$ & 16.5 & 96.4254 & 3.16491 & $97 \%$ \\
\hline 17.4 & 52.5144 & 45.4613 & $54 \%$ & 17.7 & 96.5259 & 3.04847 & $97 \%$ \\
\hline 18.6 & 54.4776 & 43.4369 & $56 \%$ & 18.8 & 96.6475 & 2.96846 & $97 \%$ \\
\hline 19.8 & 56.2225 & 41.5701 & $57 \%$ & 20.0 & 96.8076 & 2.89998 & $97 \%$ \\
\hline 21.0 & 57.9756 & 39.8627 & $59 \%$ & 21.1 & 96.8408 & 2.84504 & $97 \%$ \\
\hline 22.1 & 59.5451 & 38.2478 & $61 \%$ & 22.3 & 97.0248 & 2.76802 & $97 \%$ \\
\hline
\end{tabular}




\begin{tabular}{|c|c|c|c|c|c|c|c|}
\hline 23.3 & 60.9726 & 36.7402 & $62 \%$ & 23.5 & 97.0618 & 2.69251 & $97 \%$ \\
\hline 24.5 & 62.3687 & 35.278 & $64 \%$ & 24.6 & 97.1688 & 2.65447 & $97 \%$ \\
\hline 25.7 & 63.6742 & 33.922 & $65 \%$ & 25.8 & 97.1964 & 2.66535 & $97 \%$ \\
\hline 26.9 & 64.8684 & 32.7626 & $66 \%$ & 26.9 & 97.2631 & 2.57419 & $97 \%$ \\
\hline 28.1 & 65.9952 & 31.5634 & $68 \%$ & 28.1 & 97.3121 & 2.55492 & $97 \%$ \\
\hline 29.2 & 67.0958 & 30.4076 & $69 \%$ & 29.3 & 97.3186 & 2.57517 & $97 \%$ \\
\hline 30.4 & 68.2991 & 29.3974 & $70 \%$ & 30.5 & 97.3949 & 2.49577 & $98 \%$ \\
\hline \multicolumn{3}{|c|}{$\begin{array}{c}\text { Complex } 9 \mathrm{~g} \text { w/out } \\
\text { BSA }\end{array}$} & & \multicolumn{3}{|c|}{$\begin{array}{c}\text { Complex } 9 \mathrm{~g} \mathrm{w} / \mathrm{BSA} \\
\text { (5 mol\%) }\end{array}$} & \\
\hline $\begin{array}{c}\text { Rxn } \\
\text { Time } \\
\text { (min) } \\
\end{array}$ & $\begin{array}{l}\text { Product } \\
\text { Int }\end{array}$ & SM Int & $\begin{array}{c}\text { Conv. } \\
\text { (\%) }\end{array}$ & $\begin{array}{l}\text { Rxn } \\
\text { Time } \\
\text { (min) }\end{array}$ & $\begin{array}{l}\text { Product } \\
\text { Int }\end{array}$ & SM Int & $\begin{array}{c}\text { Conv. } \\
\text { (\%) }\end{array}$ \\
\hline 0.0 & 0 & 100 & $0 \%$ & 0.0 & 0 & 100 & $0 \%$ \\
\hline 0.9 & -0.229122 & 100 & $0 \%$ & 1.0 & 0.096948 & 99.9031 & $0 \%$ \\
\hline 2.1 & -0.008229 & 99.3256 & $0 \%$ & 2.1 & 0.255756 & 99.1703 & $0 \%$ \\
\hline 3.2 & -0.034513 & 99.1347 & $0 \%$ & 3.2 & 0.504588 & 99.0096 & $1 \%$ \\
\hline 4.4 & 0.003182 & 99.1984 & $0 \%$ & 4.4 & 0.829232 & 98.78 & $1 \%$ \\
\hline 5.6 & 0.004836 & 98.8676 & $0 \%$ & 5.5 & 1.09848 & 98.3559 & $1 \%$ \\
\hline 6.7 & 0.004288 & 98.8601 & $0 \%$ & 6.7 & 1.40705 & 98.2386 & $1 \%$ \\
\hline 7.8 & -0.176685 & 98.6489 & $0 \%$ & 7.8 & 1.77719 & 97.9462 & $2 \%$ \\
\hline 9.0 & -0.03218 & 98.712 & $0 \%$ & 8.9 & 2.03038 & 97.5603 & $2 \%$ \\
\hline 10.1 & -0.124882 & 98.5983 & $0 \%$ & 10.0 & 2.47319 & 97.3211 & $2 \%$ \\
\hline 11.2 & 0.212538 & 98.9327 & $0 \%$ & 11.1 & 2.72716 & 96.987 & $3 \%$ \\
\hline 12.4 & -0.114671 & 98.5422 & $0 \%$ & 12.3 & 3.14518 & 96.5475 & $3 \%$ \\
\hline 13.5 & 0.038869 & 98.5651 & $0 \%$ & 13.4 & 3.51544 & 96.2494 & $4 \%$ \\
\hline 14.7 & 0.150147 & 98.5715 & $0 \%$ & 14.5 & 3.80119 & 95.854 & $4 \%$ \\
\hline 15.8 & -0.201914 & 98.3515 & $0 \%$ & 15.7 & 4.08377 & 95.4675 & $4 \%$ \\
\hline 16.9 & 0.205121 & 98.6678 & $0 \%$ & 16.8 & 4.57519 & 95.1153 & $5 \%$ \\
\hline 18.1 & 0.091723 & 98.7386 & $0 \%$ & 18.0 & 4.91851 & 94.8037 & $5 \%$ \\
\hline 19.2 & 0.245683 & 98.6951 & $0 \%$ & 19.1 & 5.30226 & 94.1543 & $5 \%$ \\
\hline 20.3 & 0.212886 & 98.6709 & $0 \%$ & 20.2 & 5.64462 & 93.731 & $6 \%$ \\
\hline 21.5 & 0.269898 & 98.8922 & $0 \%$ & 21.4 & 6.04911 & 93.3396 & $6 \%$ \\
\hline 22.7 & 0.135889 & 98.6908 & $0 \%$ & 22.5 & 6.47421 & 92.8696 & $7 \%$ \\
\hline 23.8 & -0.090473 & 98.8424 & $0 \%$ & 23.7 & 6.85251 & 92.4625 & $7 \%$ \\
\hline 25.0 & 0.142239 & 98.9475 & $0 \%$ & 24.9 & 7.24716 & 92.1036 & $7 \%$ \\
\hline 26.1 & -0.017736 & 98.496 & $0 \%$ & 26.0 & 7.65542 & 91.6869 & $8 \%$ \\
\hline 27.2 & 0.208718 & 98.7192 & $0 \%$ & 27.1 & 7.99662 & 91.2518 & $8 \%$ \\
\hline 28.4 & 0.255848 & 98.7089 & $0 \%$ & 28.2 & 8.35968 & 90.842 & $8 \%$ \\
\hline 29.5 & 0.528361 & 99.0693 & $1 \%$ & 29.4 & 8.65156 & 90.4146 & $9 \%$ \\
\hline 30.7 & 0.229817 & 98.9674 & $0 \%$ & 30.6 & 9.12685 & 90.0096 & $9 \%$ \\
\hline
\end{tabular}




\section{Experimental Procedure for Table 2}

\section{High-Throughput Experimentation General Procedure:}

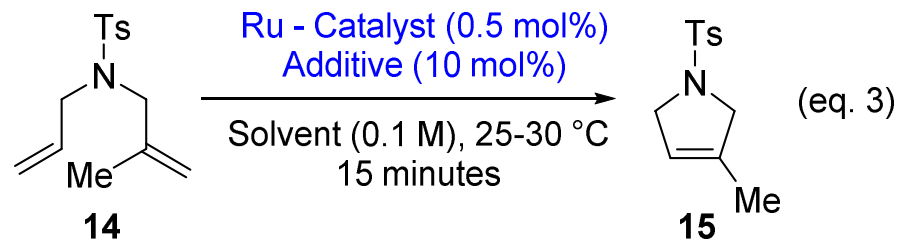

To each 8 x $30 \mathrm{~mm}$ vial in an 8x12 well plate format (Analytical Sales and Services, Inc.), positions A1 to F12, was charged N-allyl-4-methyl-N-(2-methylallyl)benzenesulfonamide (14) (10 $\mu \mathrm{mol}, 0.2 \mathrm{M})$ and 4-isopropyl-1,1'-biphenyl $(1 \mu \mathrm{mol}, 0.2 \mathrm{M})$ as a solution in THF $(50 \mu \mathrm{L})$. Upon complete addition, the rack was concentrated to remove the THF at room temperature. After concentration, to each row was then charged a Lewis or Brønsted acid co-catalyst solution (1 $\mu \mathrm{mol}, 0.02 \mathrm{M})$ either in 1,2-dichloroethane or toluene $(50 \mu \mathrm{L})$ previously prepared. Subsequently, a solution of each catalyst [9a, 9c, or 9g] $(0.05 \mu \mathrm{mol}, 0.001 \mathrm{M})$ in either in 1,2dichloroethane or toluene $(50 \mu \mathrm{L})$ was quickly charged to the respective vial and then the reaction mixtures were sealed and allowed to stir between $25-30{ }^{\circ} \mathrm{C}$ as was monitored by block temperature. After a 15 minutes age time, diisopropylethylamine $(2 \mu \mathrm{mol}, 0.02 \mathrm{M})$ in acetonitrile $(200 \mu \mathrm{L})$ was charged to each reaction mixture and subsequently, a solution of ethyl vinyl ether $(50 \mu \mathrm{mol}, 0.2 \mathrm{M})$ in acetonitrile was charged $(250 \mu \mathrm{L})$ quickly to each vial. The quenched reactions were then further diluted $(25 \mu \mathrm{l}$ aliquot was diluted into $500 \mu \mathrm{l}$ of $\mathrm{MeCN})$ for UPLC-MS analysis. The specific reagent, positions, solvents, and solution yields can be seen in the subsequent screen data table.

Screen Data for Table 2:

\begin{tabular}{|c|c|c|c|c|}
\hline Location & Solvent & Complex & Co-catalyst & $\begin{array}{c}\text { Solution Yield } \\
(\%)\end{array}$ \\
\hline 2:A:1 & DCE & $9 a$ & $\mathrm{HOAc}$ & 9.0 \\
\hline $2: A: 2$ & DCE & $9 a$ & BSA & 79.8 \\
\hline $2: A: 3$ & DCE & $9 a$ & $\mathrm{HCl}$ in dioxane $(4 \mathrm{M})$ & 87.4 \\
\hline 2:A:4 & DCE & $9 a$ & $\mathrm{HBF}_{4}$ & 86.7 \\
\hline 2:A:5 & DCE & $9 a$ & TFA & 86.6 \\
\hline 2:A:6 & DCE & $9 a$ & TFMSA & 50.9 \\
\hline 2:A:7 & DCE & $9 a$ & CSA & 87.1 \\
\hline $2: A: 8$ & DCE & $9 a$ & TCA & 86.9 \\
\hline $2: A: 9$ & DCE & $9 a$ & $\mathrm{HI}$ & 74.8 \\
\hline $2: A: 10$ & DCE & $9 a$ & $\mathrm{ZnCl}_{2}$ in THF $(0.5 \mathrm{M})$ & 6.5 \\
\hline $2: A: 11$ & DCE & $9 a$ & $\mathrm{AlCl}_{3}$ in $\mathrm{THF}(0.5 \mathrm{M})$ & 88.0 \\
\hline $2: A: 12$ & DCE & $9 a$ & Control & 17.8 \\
\hline $2: B: 1$ & DCE & $9 g$ & $\mathrm{HOAc}$ & 0.2 \\
\hline $2: B: 2$ & DCE & $9 g$ & BSA & 6.1 \\
\hline $2: B: 3$ & DCE & $9 g$ & $\mathrm{HCl}$ in dioxane $(4 \mathrm{M})$ & 0.1 \\
\hline
\end{tabular}




\begin{tabular}{|c|c|c|c|c|}
\hline 2:B:4 & DCE & $9 g$ & $\mathrm{HBF}_{4}$ & 1.6 \\
\hline 2:B:5 & DCE & $9 g$ & TFA & 0.2 \\
\hline 2:B:6 & DCE & $9 g$ & TFMSA & 1.0 \\
\hline 2:B:7 & DCE & $9 g$ & CSA & 0.1 \\
\hline $2: B: 8$ & DCE & $9 g$ & TCA & 0.1 \\
\hline $2: B: 9$ & DCE & $9 g$ & $\mathrm{HI}$ & 0.3 \\
\hline $2: B: 10$ & DCE & $9 g$ & $\mathrm{ZnCl}_{2}$ in THF $(0.5 \mathrm{M})$ & 0.1 \\
\hline $2: B: 11$ & DCE & $9 g$ & $\mathrm{AlCl}_{3}$ in $\mathrm{THF}(0.5 \mathrm{M})$ & 5.1 \\
\hline $2: B: 12$ & DCE & $9 g$ & Control & 0.2 \\
\hline $2: C: 1$ & DCE & $9 c$ & HOAc & 31.5 \\
\hline 2:C:2 & DCE & $9 c$ & BSA & 93.9 \\
\hline 2:C:3 & DCE & $9 c$ & $\mathrm{HCl}$ in dioxane $(4 \mathrm{M})$ & 83.7 \\
\hline 2:C:4 & DCE & $9 c$ & $\mathrm{HBF}_{4}$ & 96.5 \\
\hline 2:C:5 & DCE & $9 c$ & TFA & 75.2 \\
\hline 2:C:6 & DCE & $9 c$ & TFMSA & 44.6 \\
\hline 2:C:7 & DCE & $9 c$ & CSA & 65.2 \\
\hline 2:C:8 & DCE & $9 c$ & TCA & 75.2 \\
\hline $2: C: 9$ & DCE & $9 c$ & $\mathrm{HI}$ & 62.0 \\
\hline $2: C: 10$ & DCE & $9 c$ & $\mathrm{ZnCl}_{2}$ in THF $(0.5 \mathrm{M})$ & 11.2 \\
\hline $2: C: 11$ & DCE & $9 c$ & $\mathrm{AlCl}_{3}$ in $\mathrm{THF}(0.5 \mathrm{M})$ & 96.3 \\
\hline $2: C: 12$ & DCE & $9 c$ & Control & 29.4 \\
\hline $2: D: 1$ & toluene & $9 a$ & $\mathrm{HOAC}$ & 58.7 \\
\hline 2:D:2 & toluene & $9 a$ & BSA & 85.9 \\
\hline 2:D:3 & toluene & $9 a$ & $\mathrm{HCl}$ in dioxane $(4 \mathrm{M})$ & 78.4 \\
\hline 2:D:4 & toluene & $9 a$ & $\mathrm{HBF}_{4}$ & 93.5 \\
\hline 2:D:5 & toluene & $9 a$ & TFA & 88.7 \\
\hline 2:D:6 & toluene & $9 a$ & TFMSA & 44.5 \\
\hline 2:D:7 & toluene & $9 a$ & CSA & 86.6 \\
\hline 2:D:8 & toluene & $9 a$ & TCA & 86.5 \\
\hline $2: D: 9$ & toluene & $9 a$ & $\mathrm{HI}$ & 69.0 \\
\hline 2:D:10 & toluene & $9 a$ & $\mathrm{ZnCl}_{2}$ in THF $(0.5 \mathrm{M})$ & 18.2 \\
\hline 2:D:11 & toluene & $9 a$ & $\mathrm{AlCl}_{3}$ in $\mathrm{THF}(0.5 \mathrm{M})$ & 92.5 \\
\hline 2:D:12 & toluene & $9 a$ & Control & 59.5 \\
\hline $2: E: 1$ & toluene & $9 g$ & HOAc & 0.3 \\
\hline $2: E: 2$ & toluene & $9 g$ & BSA & 1.6 \\
\hline $2: E: 3$ & toluene & $9 g$ & $\mathrm{HCl}$ in dioxane $(4 \mathrm{M})$ & 0.1 \\
\hline $2: E: 4$ & toluene & $9 g$ & $\mathrm{HBF}_{4}$ & 0.9 \\
\hline $2: E: 5$ & toluene & $9 g$ & TFA & 0.1 \\
\hline 2:E:6 & toluene & $9 \mathrm{~g}$ & TFMSA & 1.0 \\
\hline 2:E:7 & toluene & $9 \mathrm{~g}$ & CSA & 0.1 \\
\hline $2: E: 8$ & toluene & $9 \mathrm{~g}$ & TCA & 0.1 \\
\hline $2: E: 9$ & toluene & $9 g$ & $\mathrm{HI}$ & 0.1 \\
\hline $2: E: 10$ & toluene & $9 g$ & $\mathrm{ZnCl}_{2}$ in THF $(0.5 \mathrm{M})$ & 0.1 \\
\hline $2: E: 11$ & toluene & $9 g$ & $\mathrm{AlCl}_{3}$ in $\mathrm{THF}(0.5 \mathrm{M})$ & 0.4 \\
\hline $2: E: 12$ & toluene & $9 g$ & Control & 0.0 \\
\hline $2: F: 1$ & toluene & $9 c$ & $\mathrm{HOAC}$ & 70.4 \\
\hline $2: F: 2$ & toluene & $9 c$ & BSA & 93.7 \\
\hline $2: F: 3$ & toluene & $9 c$ & $\mathrm{HCl}$ in dioxane $(4 \mathrm{M})$ & 76.4 \\
\hline $2: F: 4$ & toluene & $9 c$ & $\mathrm{HBF}_{4}$ & 96.8 \\
\hline $2: F: 5$ & toluene & $9 c$ & TFA & 83.3 \\
\hline $2: F: 6$ & toluene & $9 c$ & TFMSA & 33.2 \\
\hline
\end{tabular}




\begin{tabular}{|lllcl|} 
2:F:7 & toluene & 9c & CSA & 73.1 \\
2:F:8 & toluene & 9c & TCA & 79.1 \\
2:F:9 & toluene & 9c & HI & 82.3 \\
2:F:10 & toluene & 9c & $\mathrm{ZnCl}_{2}$ in THF $(0.5 \mathrm{M})$ & 30.7 \\
2:F:11 & toluene & 9c & $\mathrm{AlCl}_{3}$ in THF $(0.5 \mathrm{M})$ & 95.3 \\
2:F:12 & toluene & 9c & Control & 73.0 \\
\hline
\end{tabular}

\section{Experimental procedures for Table 3}

\section{Ring-closing Metathesis Procedures (Table 3; Entries 1-8)}

In a glove box was prepared reaction mixtures containing diene substrates 14, or 16 (100 $\mathrm{mg}$ ) in DCM or toluene (4 ml). To this was added a solution of catalyst 9a in DCM (0.1 M, 1 mol\%). The resulting mixture was stirred at $30{ }^{\circ} \mathrm{C}$ in the presence or absence of $\mathrm{AlCl}_{3}(0.2$ eq. Added as a $0.5 \mathrm{M}$ THF solution). Aliquots were taken and analyzed with HPLC to monitor the conversion. When the reaction was completed (LC conversion > 99\%), the reaction mixture was cooled to room temperature, diluted with aq. acetonitrile, and quantitatively assayed with HPLC.

\begin{tabular}{|c|c|c|c|c|}
\hline $\begin{array}{c}\text { LC conv } \\
\text { (Assay Yield) }\end{array}$ & $0.5 \mathrm{~h}$ & $1.5 \mathrm{~h}$ & $3 \mathrm{~h}$ & $6 \mathrm{~h}$ \\
\hline 1 & $\begin{array}{c}100 \% \\
(99.8 \%) \\
\end{array}$ & & & \\
\hline 2 & $\begin{array}{l}100 \% \\
(94.5 \%)\end{array}$ & & & \\
\hline 3 & $82 \%$ & $89 \%$ & $94 \%$ & $\begin{array}{c}97 \% \\
(98.6 \%)\end{array}$ \\
\hline 4 & & & $98 \%$ & $\begin{array}{c}100 \% \\
(98.7 \%) \\
\end{array}$ \\
\hline 5 & $\begin{array}{c}97 \% \\
(94.2 \%) \\
\end{array}$ & & & \\
\hline 6 & $\begin{array}{l}100 \% \\
(95.0 \%) \\
\end{array}$ & & & \\
\hline 7 & & $80 \%$ & $87 \%$ & $\begin{array}{c}93 \% \\
(91.7 \%) \\
\end{array}$ \\
\hline 8 & & & $99 \%$ & $\begin{array}{c}100 \% \\
(97.0 \%) \\
\end{array}$ \\
\hline
\end{tabular}

\section{Representative Procedure for Isolation of RCM (Table 3; Entry 8)}

In a glove box was prepared reaction mixtures containing diene substrates $14(1.0 \mathrm{~g}, 3.73$ $\mathrm{mmol})$ in degassed toluene $(40 \mathrm{ml})$. To this was added catalyst $9 \mathbf{a}(27 \mathrm{mg}, 0.037 \mathrm{mmol}, 1 \mathrm{~mol}$ $\%)$. The resulting mixture was stirred at $30{ }^{\circ} \mathrm{C}$ for 6 hour. The reaction mixture was cooled to 
room temperature and concentrated to $10 \mathrm{~mL}$ under reduced pressure. The $\mathrm{SiO}_{2}$ purification $($ EtOAc/DCM/hexane $=1 / 2 / 10)$ of the crude material afforded a white solid product $(0.831 \mathrm{~g}$, 95\% isolated yield). ${ }^{1} \mathrm{H}$ NMR of the isolated material was matched with the known compound 15. ${ }^{3}$ 15: ${ }^{1} \mathrm{H}$ NMR $\left(\mathrm{CDCl}_{3}, 500 \mathrm{MHz}\right): 7.73-7.71(\mathrm{~m}, 2 \mathrm{H}), 7.33$ - $7.31(\mathrm{~m}, 2 \mathrm{H}), 5.26$ - $5.24(\mathrm{~m}$, 1H), $4.09-4.06(\mathrm{~m}, 2 \mathrm{H}), 3.98-3.96(\mathrm{~m}, 2 \mathrm{H}), 2.43(\mathrm{~s}, 3 \mathrm{H}), 1.67-1.65(\mathrm{~m}, 3 \mathrm{H})$.

\section{Ring-opening Metathesis Polymerization Procedure (Table 3; Entries 9-10)}

In a glove box were prepared reaction mixtures containing cyclooctadiene $18(0.40$ $\mathrm{mmol}, 43 \mathrm{mg})$ in $\mathrm{CD}_{2} \mathrm{Cl}_{2}(0.74 \mathrm{ml})$. To this was added a solution of catalyst 9a in $\mathrm{CD}_{2} \mathrm{Cl}_{2}(0.01$ $\mathrm{M}, 0.1 \mathrm{~mol} \%$ ). The resulting mixture was stirred at $30{ }^{\circ} \mathrm{C}$ in the presence or absence of $\mathrm{AlCl}_{3}$ (0.02 eq. Added as a $0.5 \mathrm{M}$ THF solution). The conversion to 19 was determined by comparing the ratio of the integrals of the methylene protons in the starting material, $\delta 2.36(\mathrm{~m})$, with those in the product, $\delta 2.09$ (br m), 2.04 (br m).

\section{Cross-metathesis Procedures (Table 3; Entries 11-12)}

In a glovebox, a catalyst stock solution was prepared by dissolving complex 9a (36.2 mg) in toluene-d6 $(5 \mathrm{~mL})$. To two separate NMR tubes, in a glovebox, with screw top septa was charged either tetrahydrofuran $(157 \mu \mathrm{L})$ or AlCl3 $\bullet$ THF complex $0.5 \mathrm{M}$ in THF $(157 \mu \mathrm{L}, 0.078$ mmol, $20 \mathrm{~mol} \%)$ and then toluene-d6 $(158 \mu \mathrm{L})$. The solution of complex 9a prepared above $(400 \mu \mathrm{L}, 3.92 \mu \mathrm{mol}, 1 \mathrm{~mol} \%)$ was then charged each NMR tube. Finally, 1-hexene $(50 \mu \mathrm{L}, 0.39$ mmol, $0.5 \mathrm{M}$ ) was charged to each tube via a $50 \mu \mathrm{L}$ syringe. The NMR tubes were then sealed and the contents mixed, after which time they were brought out of the glovebox and allowed to age $(16 \mathrm{~h})$ at room temperature $\left(23^{\circ} \mathrm{C}\right)$. The conversion to dodecane $(\mathbf{2 1})$ was determined by comparing the ratio of integrals of the methylene protons in the starting material with those of the product which was determined to be $99 \%$ (entry 11, table 3) for sample containing $\mathrm{AlCl}_{3}$ and $97 \%$ for the background (entry 12, table 3). ${ }^{10}$ The ${ }^{1} \mathrm{H}$ NMR spectrum of the desired product matched the corresponding ${ }^{1} \mathrm{H}$ NMR's of cis-5-decene and trans-5-decene which are commercially available. ${ }^{4}$

\section{Experimental Procedure for Figure 4}

In a glovebox, a catalyst stock solution was prepared by dissolving complex $\mathbf{9 g}$, from Complex $9 \mathrm{~g}$ procedure $\mathrm{B},(21.0 \mathrm{mg})$ in toluene- $d_{6}(5 \mathrm{~mL})$. To four separate $\mathrm{J}$-Young (sealable) NMR tubes was charged $0.715 \mathrm{~mL}$ of the complex $9 \mathrm{~g}$ stock solution $(3.01 \mathrm{mg}, 3.92 \mu \mathrm{mol}, 1 \mathrm{~mol} \%$ ). Subsequently, to each tube was charged 1-hexene $(50 \mu \mathrm{L}, 0.39 \mathrm{mmol}, 0.5 \mathrm{M})$ via a $50 \mu \mathrm{L}$ syringe. The NMR tubes were then sealed and the contents mixed, after which time they were

\footnotetext{
${ }^{10}$ See the following reference for representative example: Thomas, R. M.; Fedorov, A.; Keitz, B. K.; Grubbs, R. H. Organometallics 2011, 30, 6713.
} 
brought out of the glovebox and separately heated to the following temperatures independently sealed at $23,50,75$, and $95{ }^{\circ} \mathrm{C}$ in an oil bath for 24 hours. ${ }^{10} \mathrm{~A}{ }^{1} \mathrm{H}$ NMR spectrum was taken to determine the percent conversion of 1-hexene (20) to 5-decene (21) for each sample. All samples were observed to show a clean conversion of starting material to desired product where observed. The ' ${ }^{1} \mathrm{H}$ NMR spectrum of the desired product matched the corresponding ${ }^{1} \mathrm{H}$ NMR's of cis-5-decene and trans-5-decene which are commercially available. ${ }^{4}$

\begin{tabular}{ccc}
20 & \multicolumn{2}{c}{ Complex $9 \mathrm{~g}(1 \mathrm{~mol} \%)$} \\
\cline { 2 - 3 } & toluene- $d_{8}, 24 \mathrm{~h}$, temp ${ }^{\circ} \mathrm{C}$ & 21 \\
\hline Entry ${ }^{\mathrm{a}}$ & Temperature $\left({ }^{\circ} \mathrm{C}\right)$ & Conversion $(\%)^{\mathrm{b}}$ \\
\hline 1 & 23 & $<5$ \\
2 & 50 & 8 \\
3 & 75 & 27 \\
4 & 95 & 90 \\
\hline
\end{tabular}




\section{NMR Spectra}

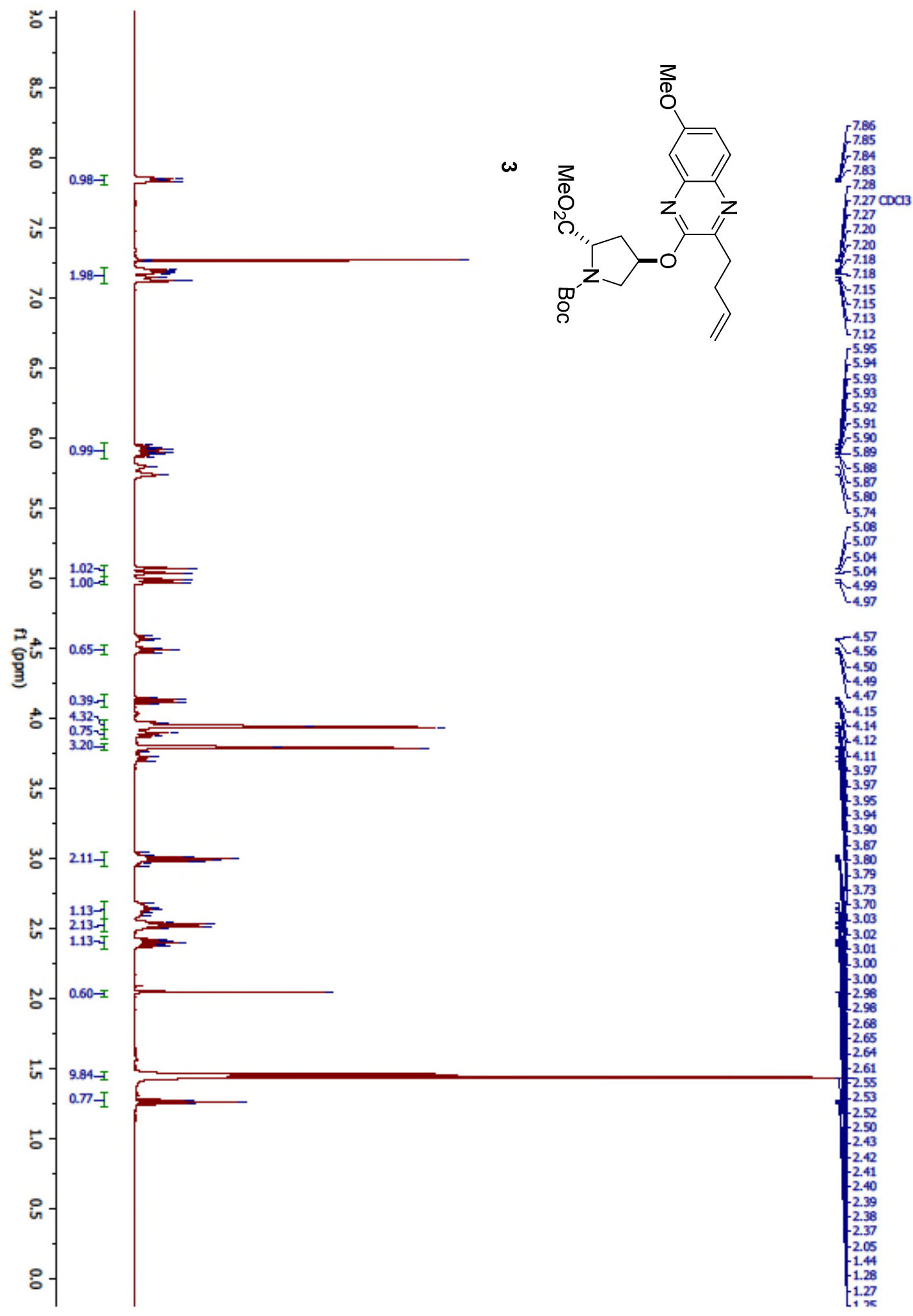




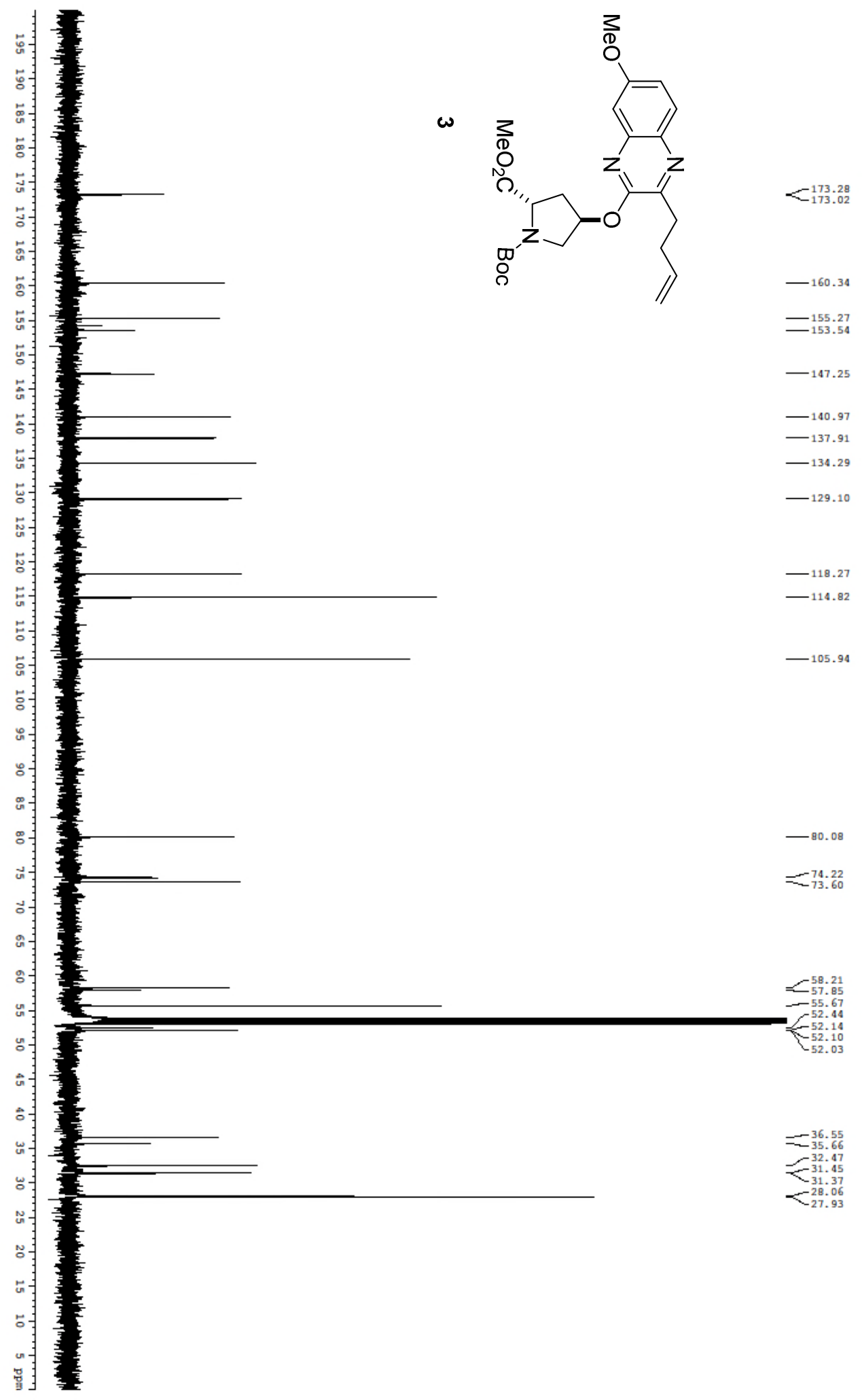




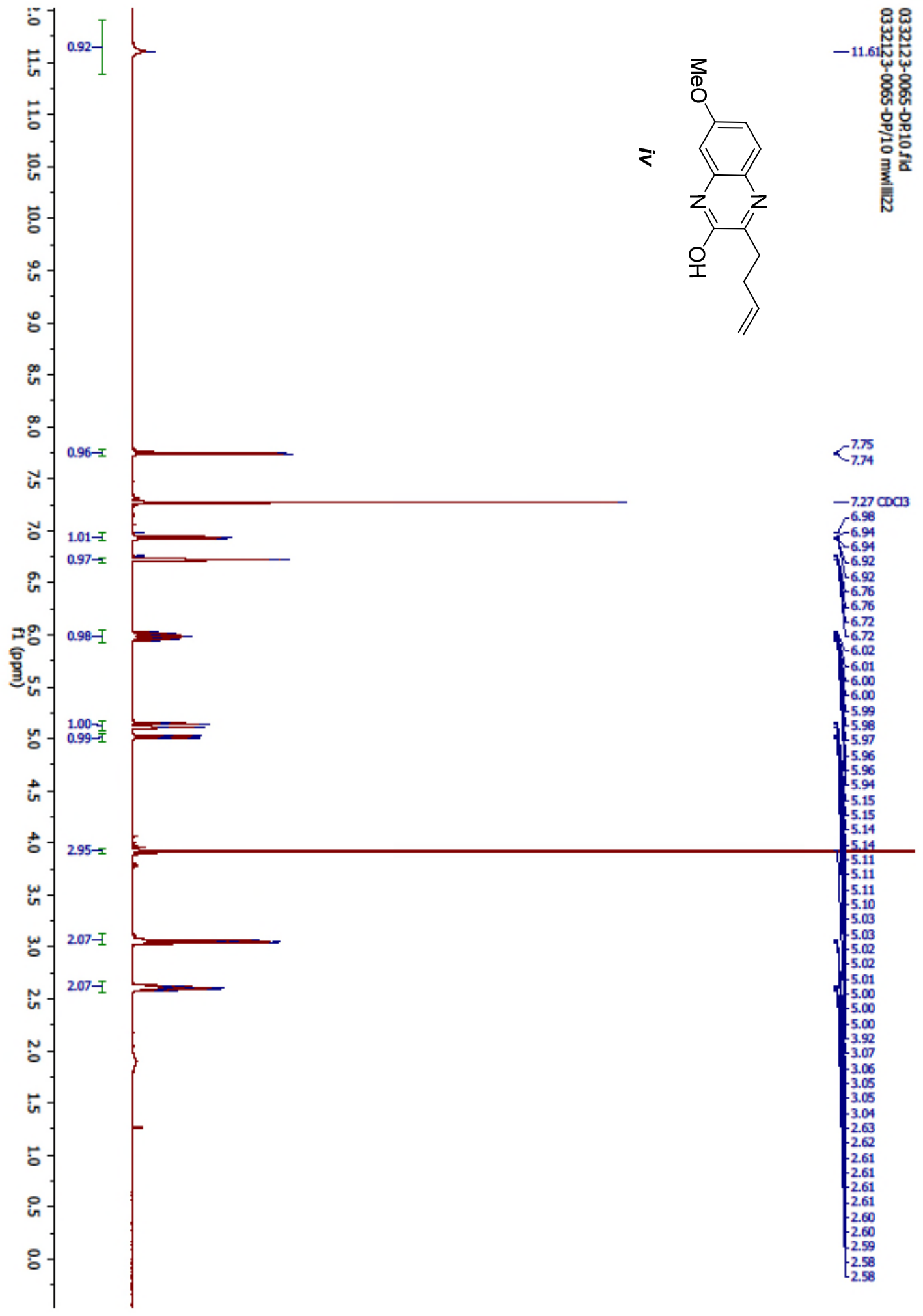




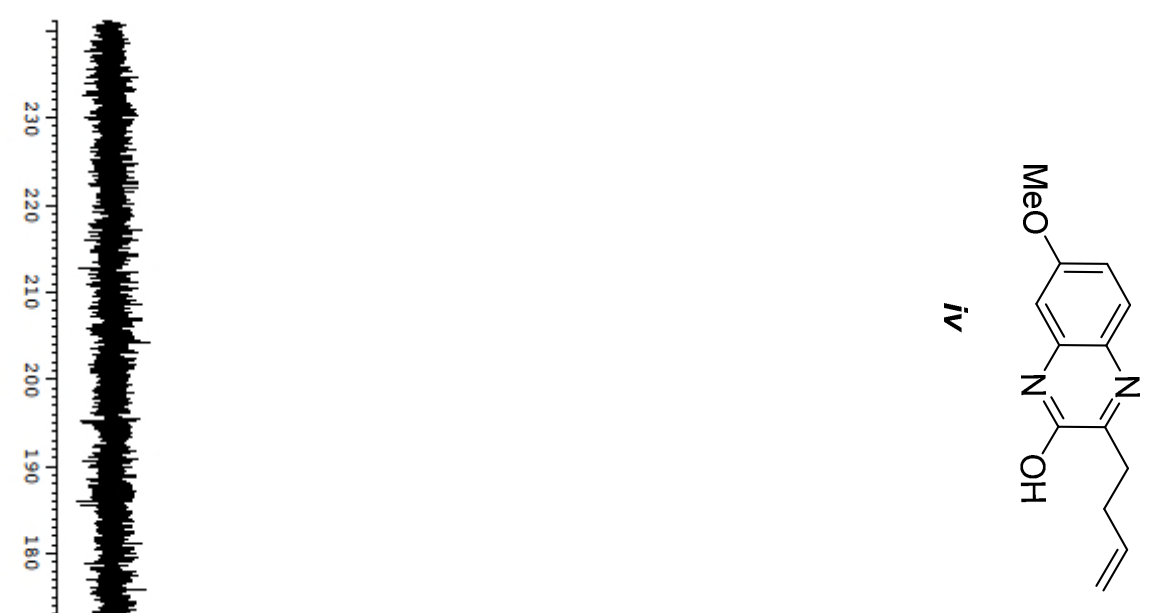

${ }^{161.08}$ $<156.87$

$-138.02$

$\begin{array}{r}132.62 \\ -130.25 \\ \hline\end{array}$

115.37
-113.03

$-98.23$

$-56.02$

$=-32.71$ 


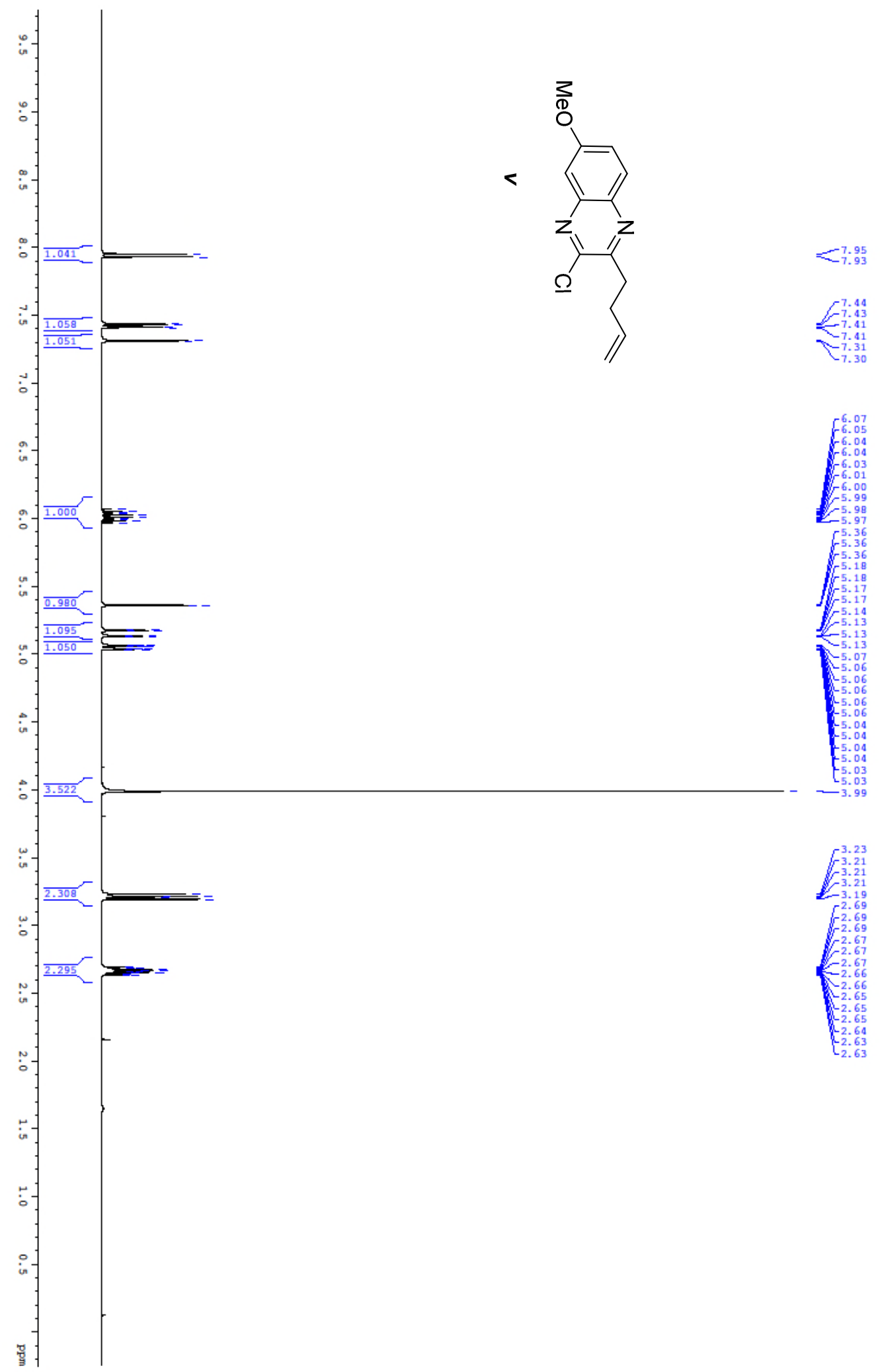



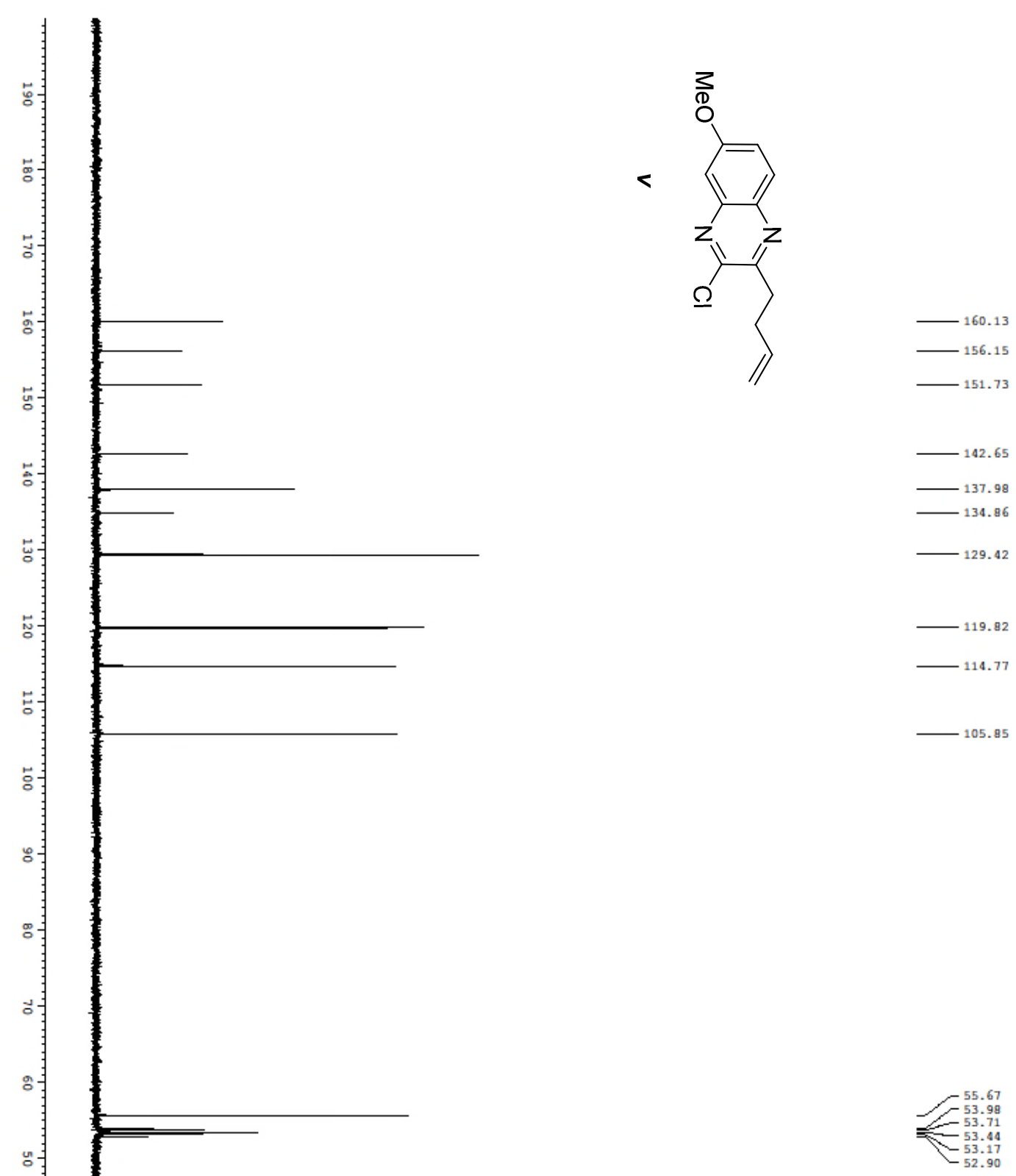

$=\sqsubseteq \begin{gathered}33.98 \\ 33.05 \\ 31.07\end{gathered}$ 


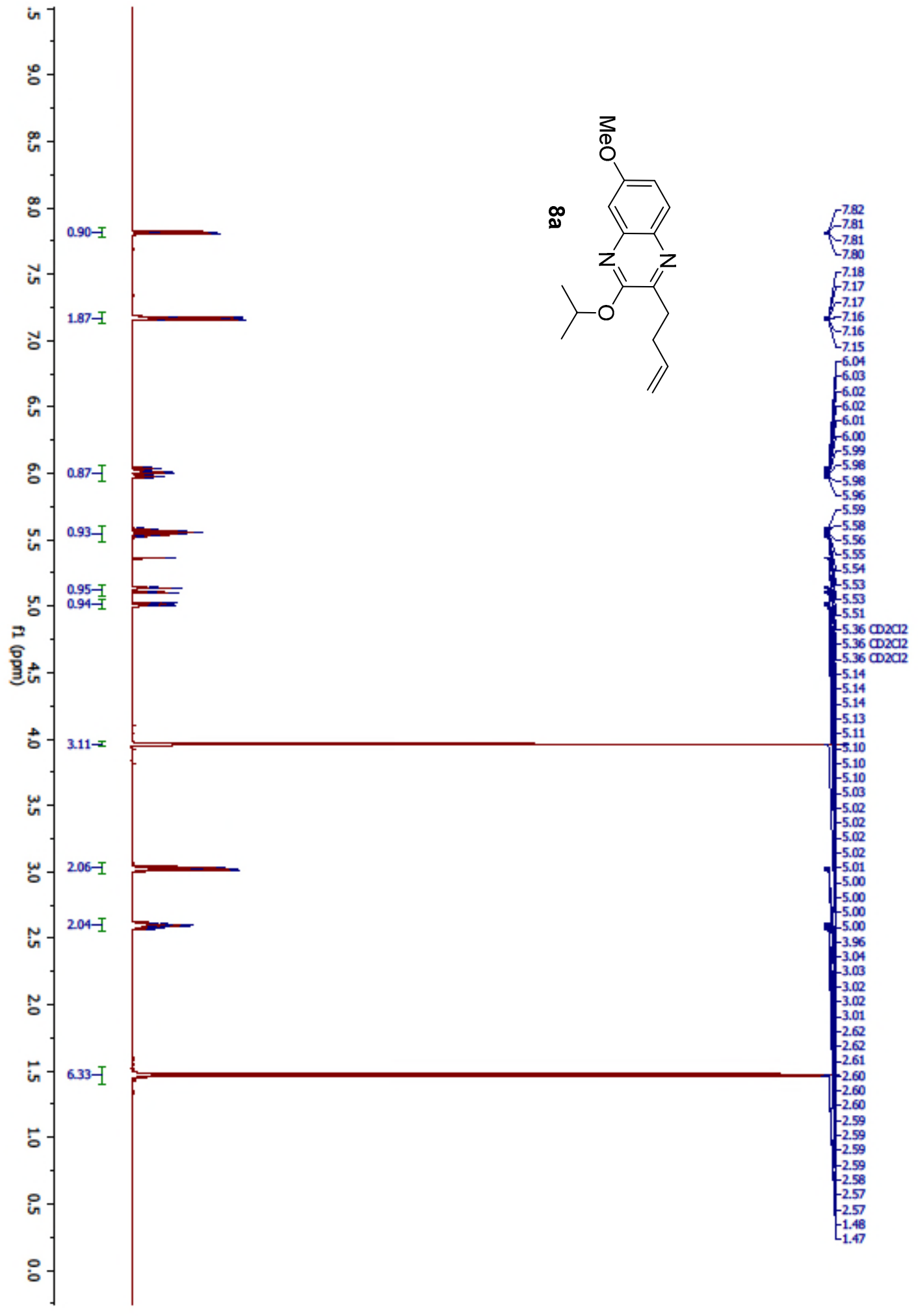




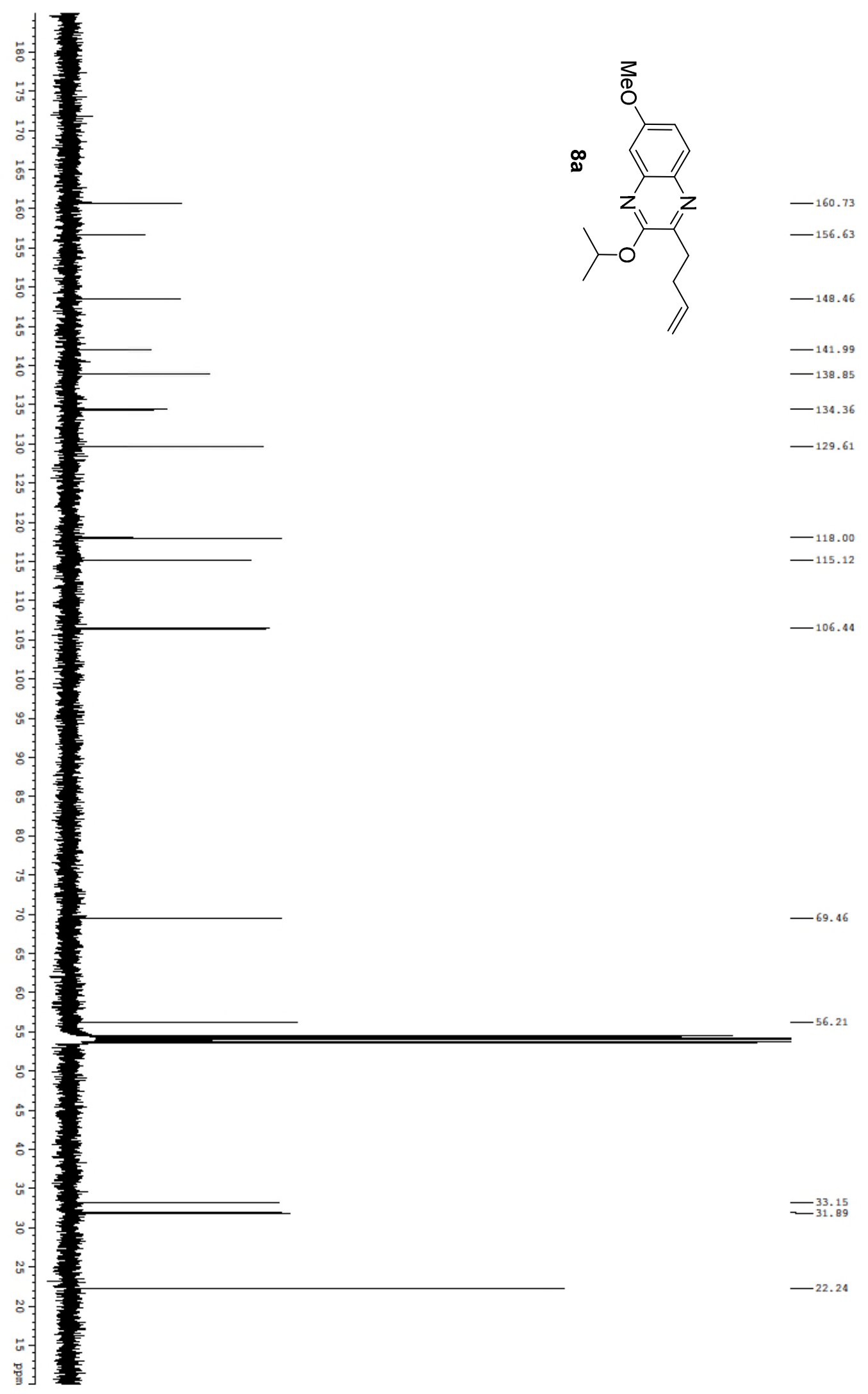




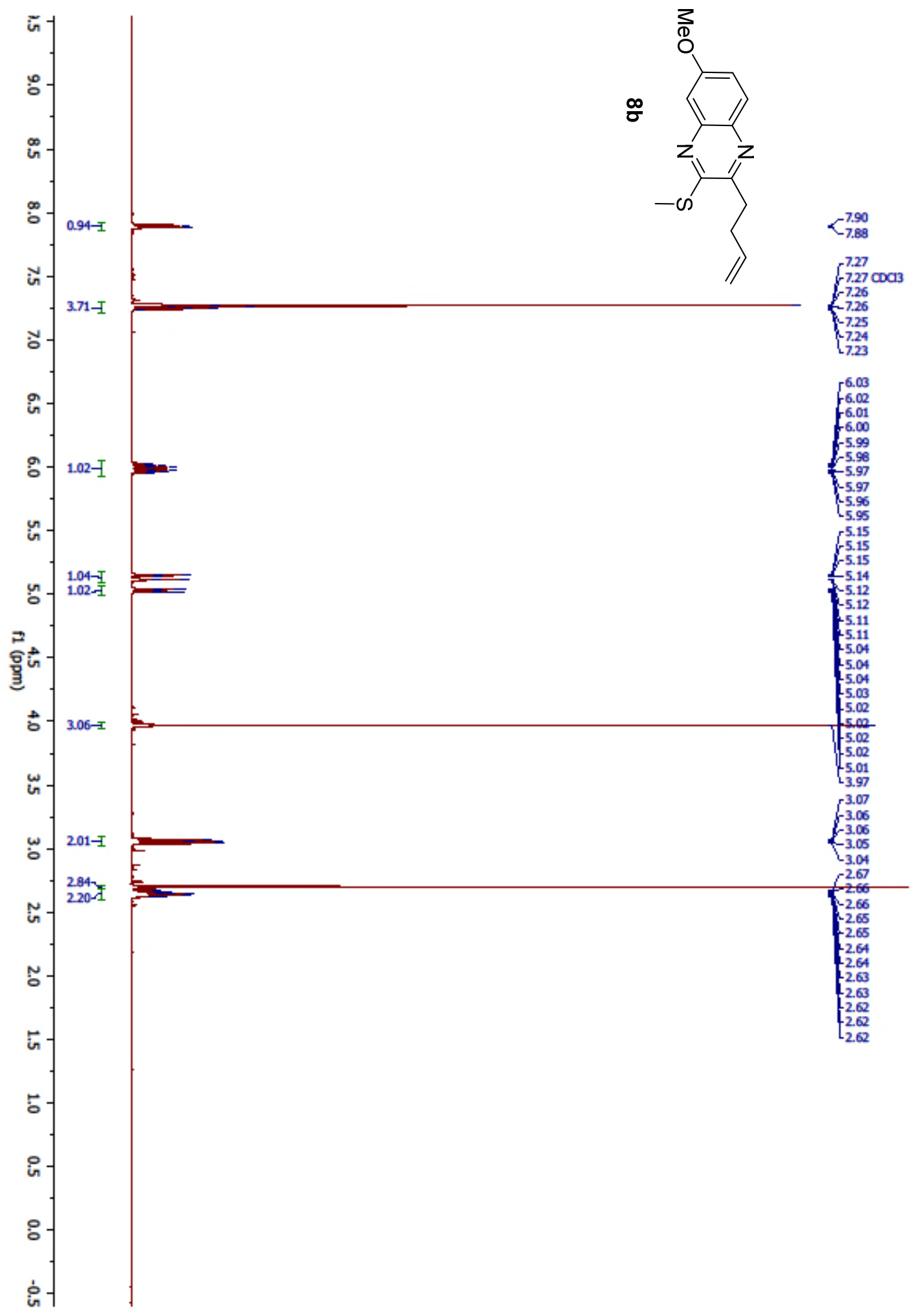

- 44 - 


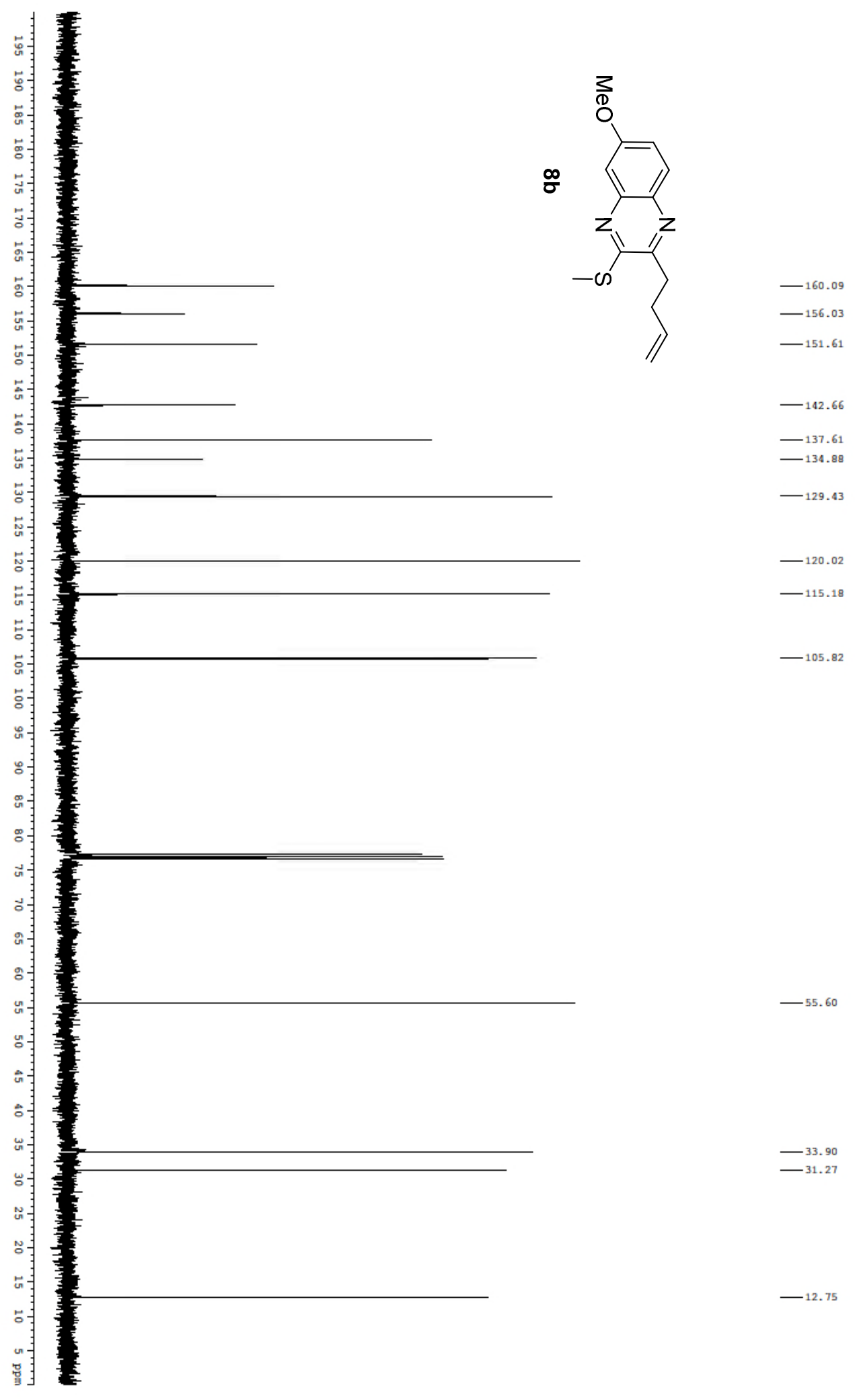




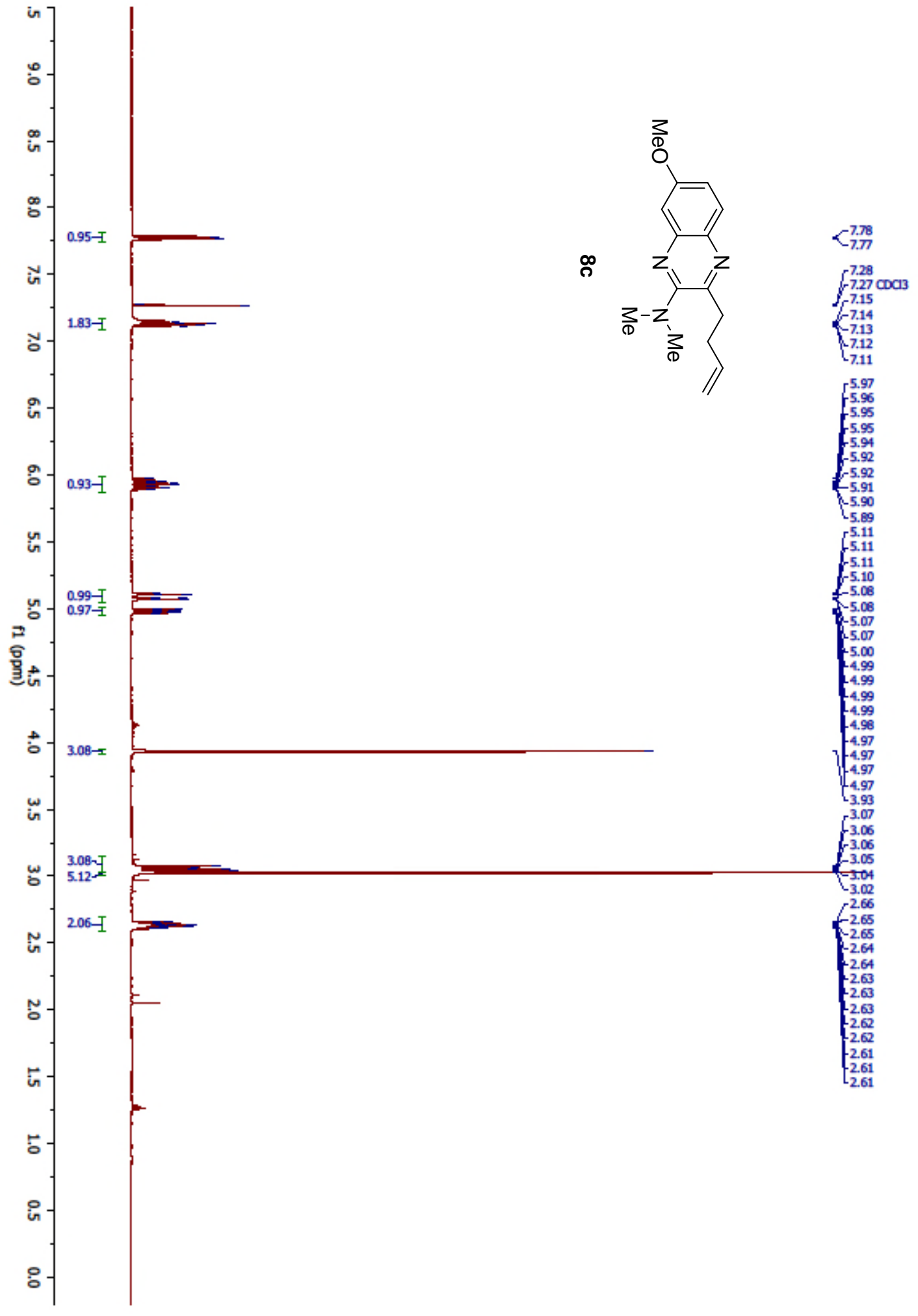

- 46 - 


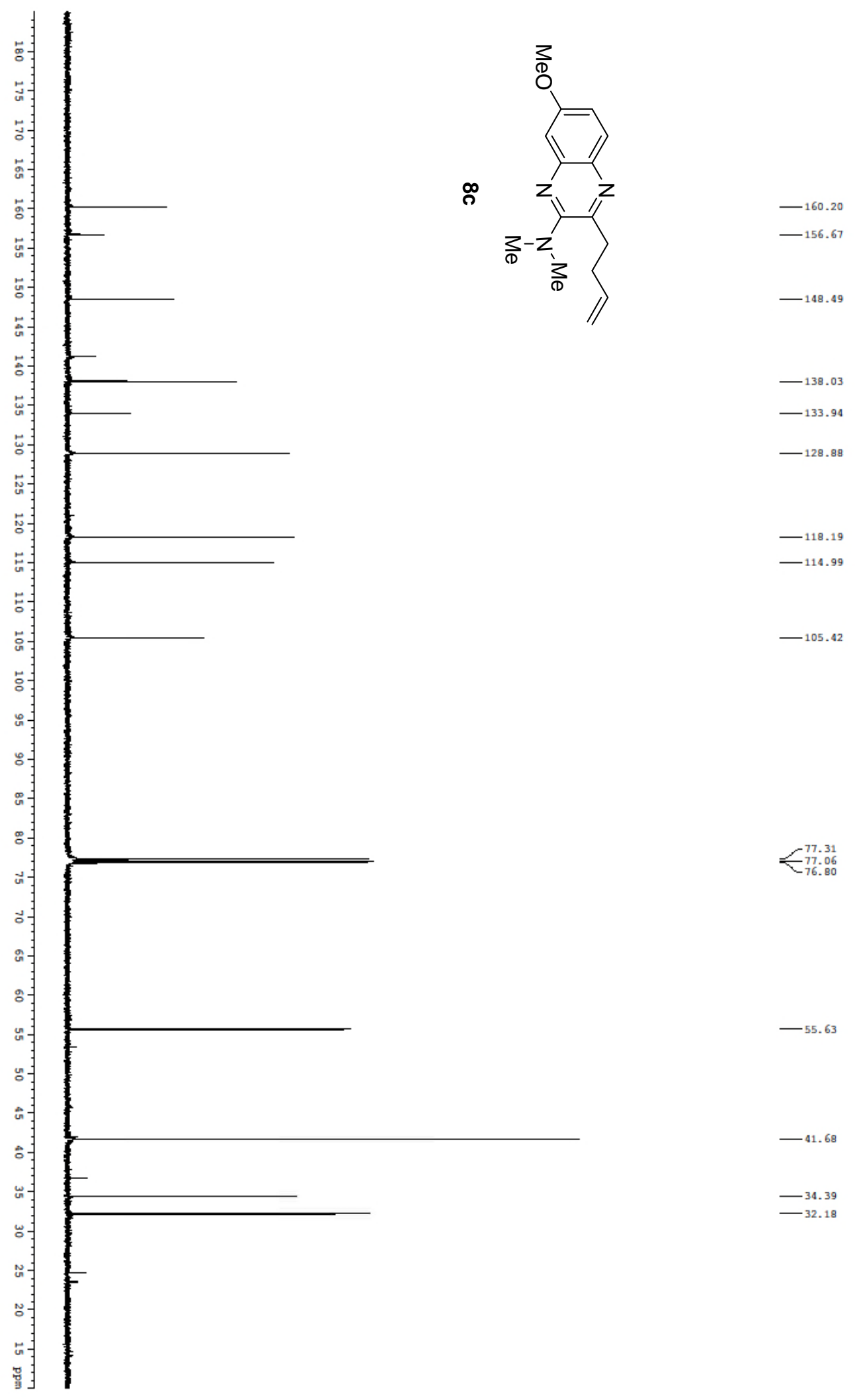




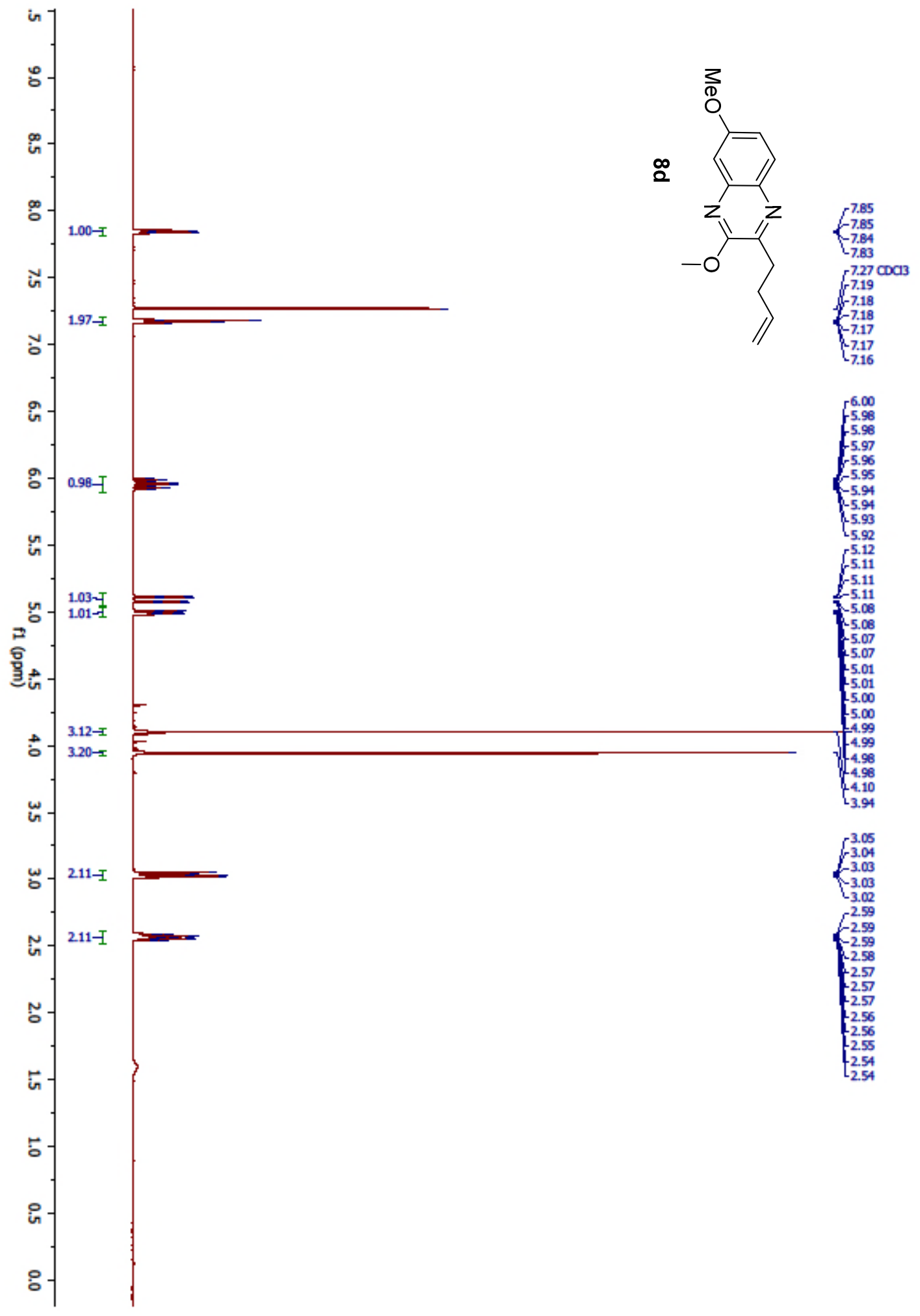




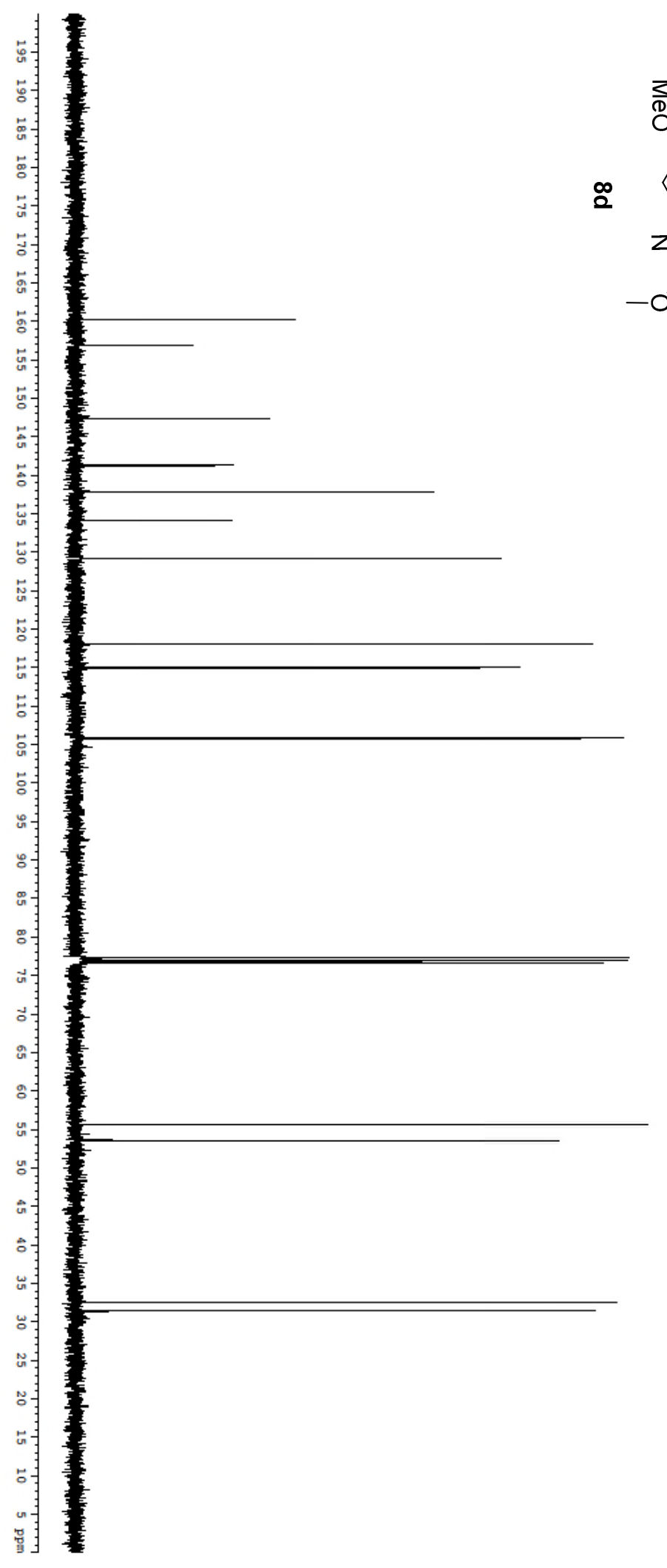

160.19
-156.80

${ }^{147.32}$

${ }^{141.27}$

$-137.85$

- 134.07

$-129.16$

$-118.05$

${ }^{114.98}$

${ }^{105.81}$

55.61
-53.56

$=-32.53$ 


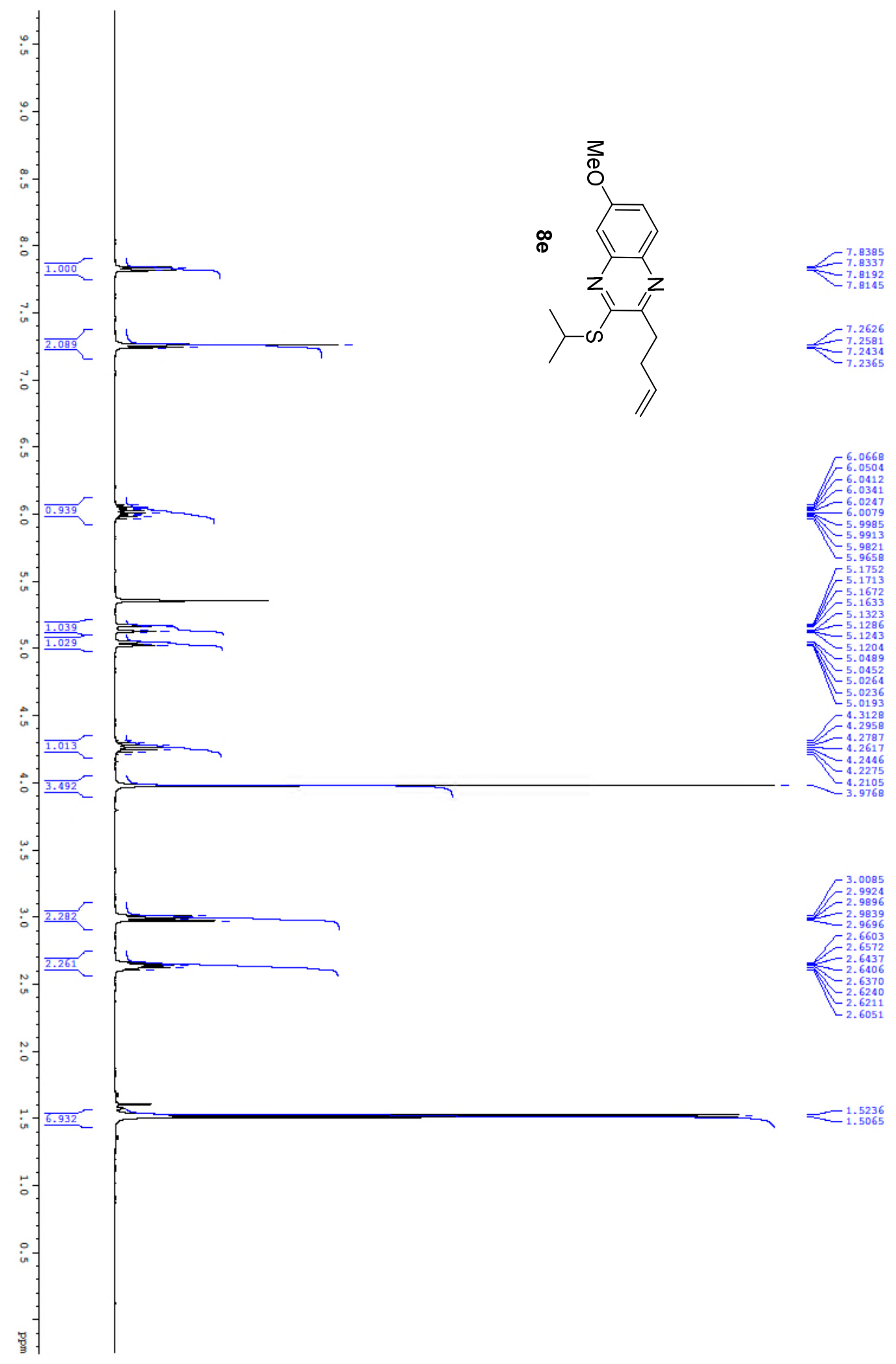




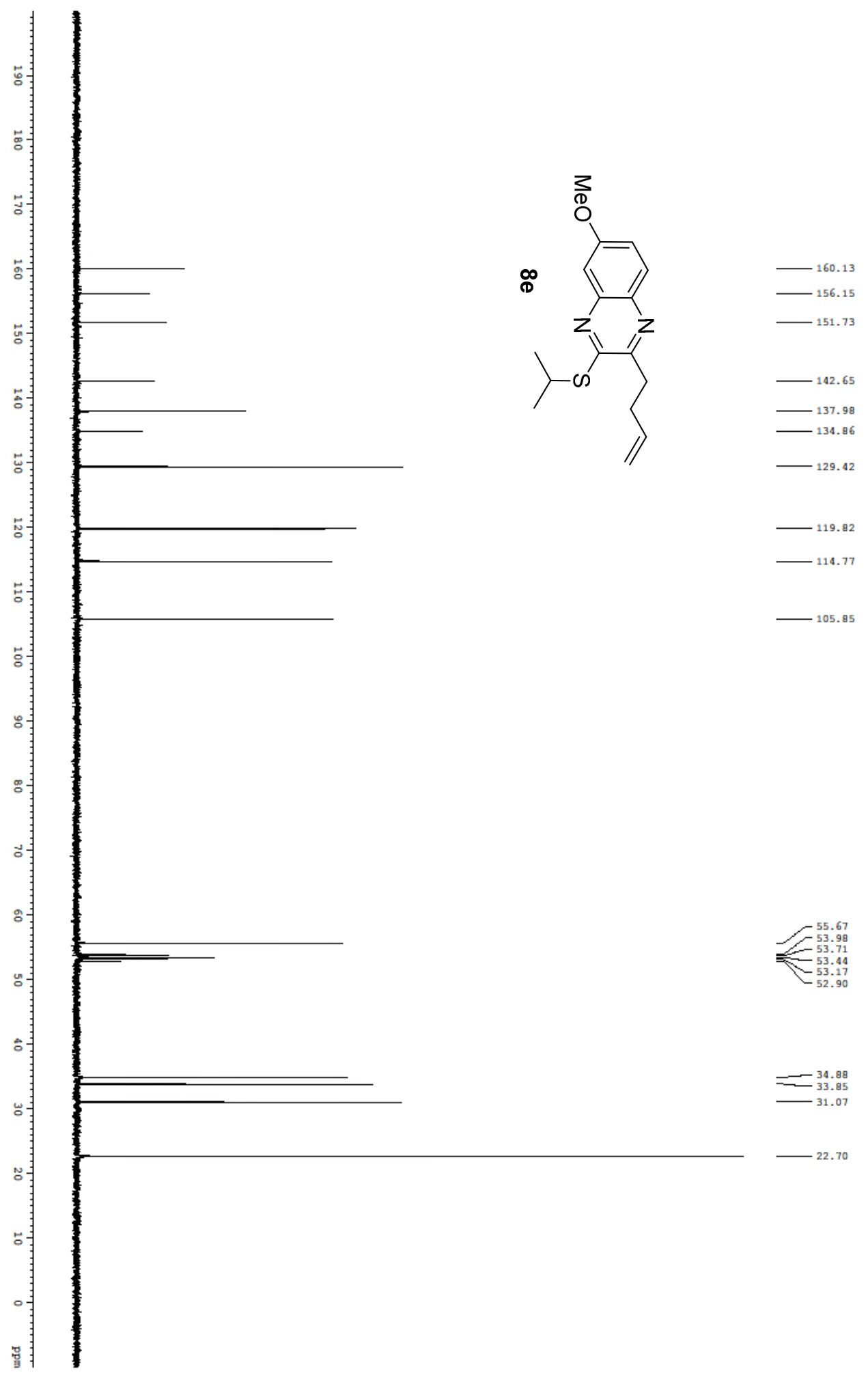




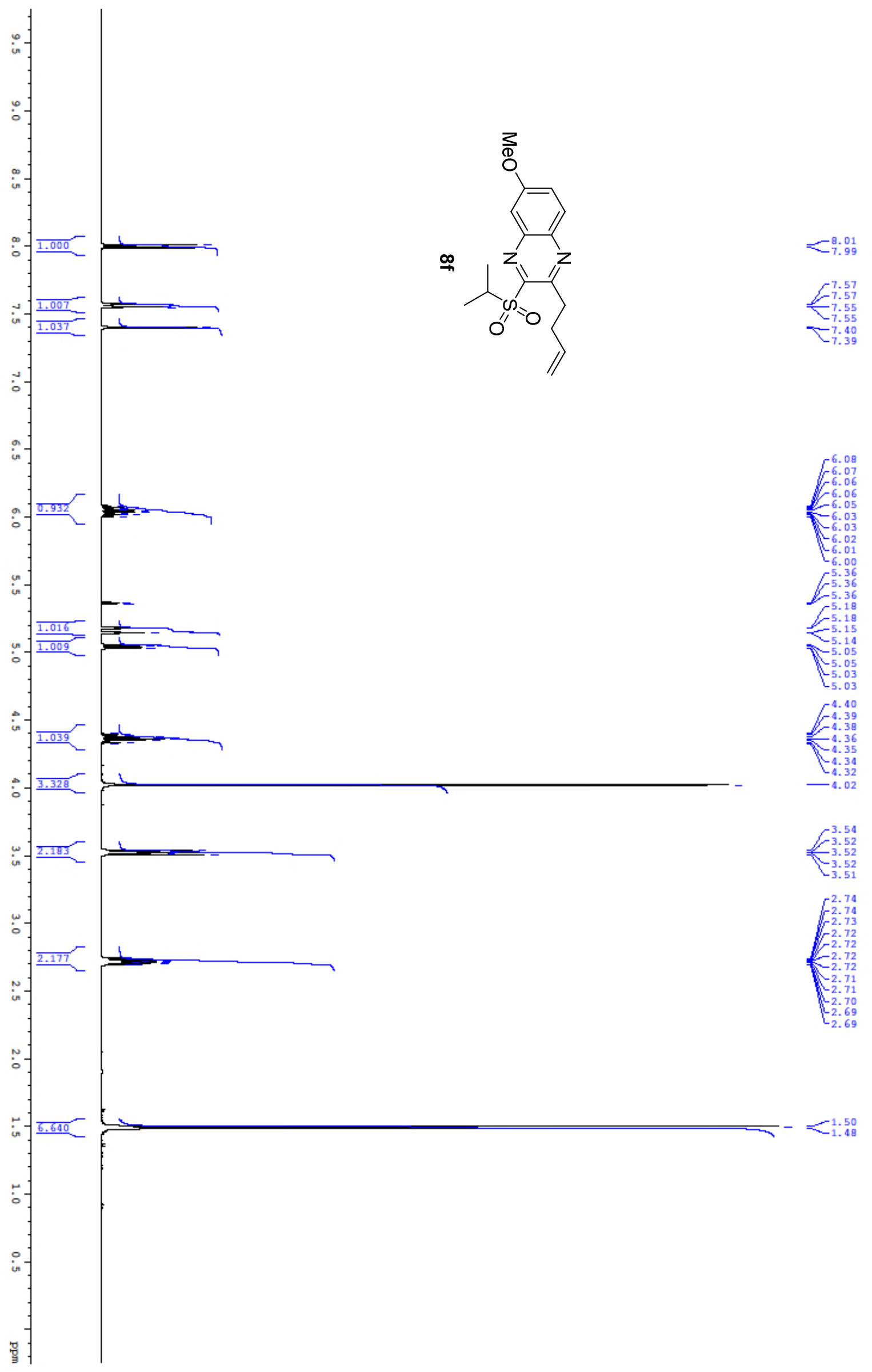




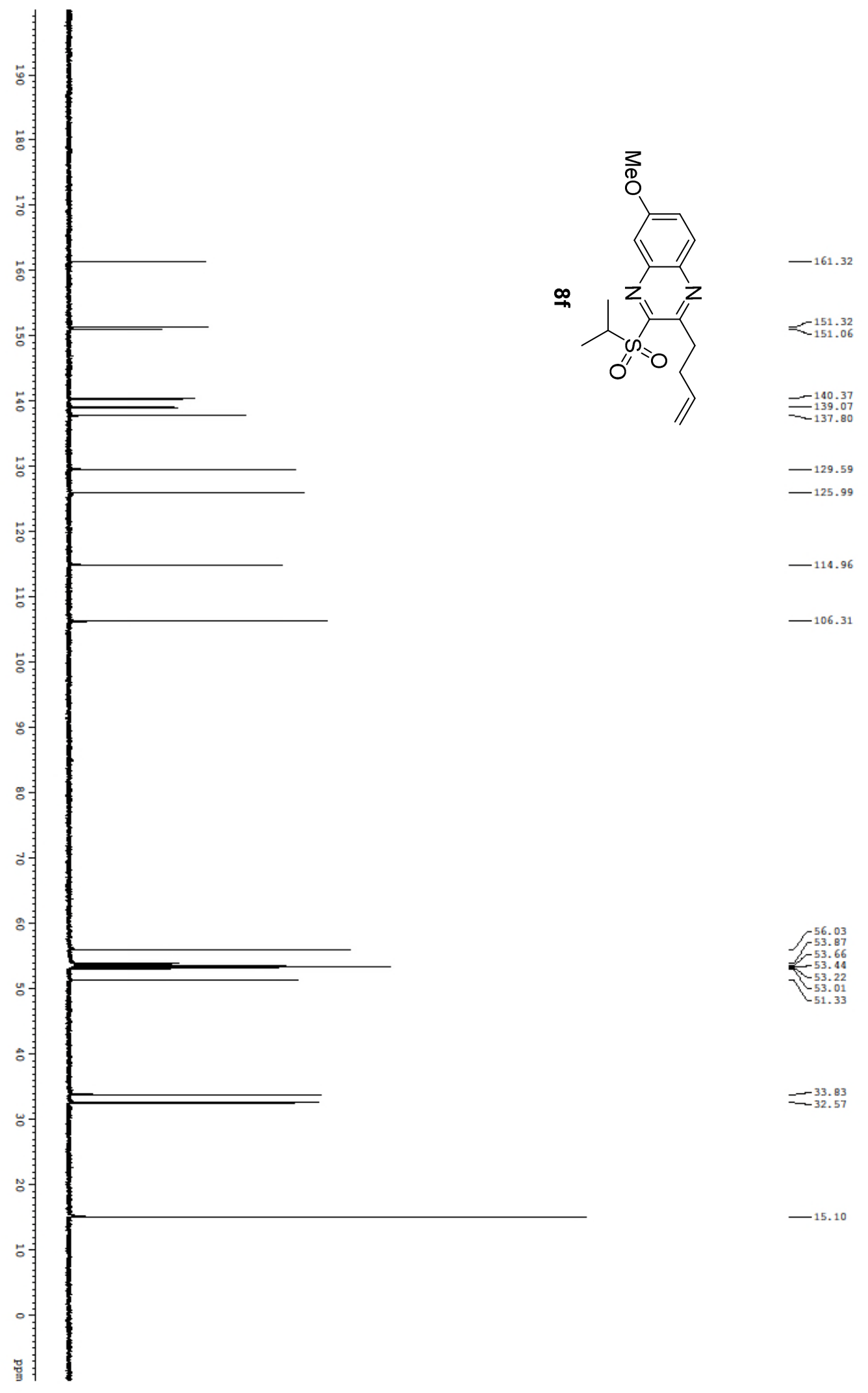

$-53-$ 


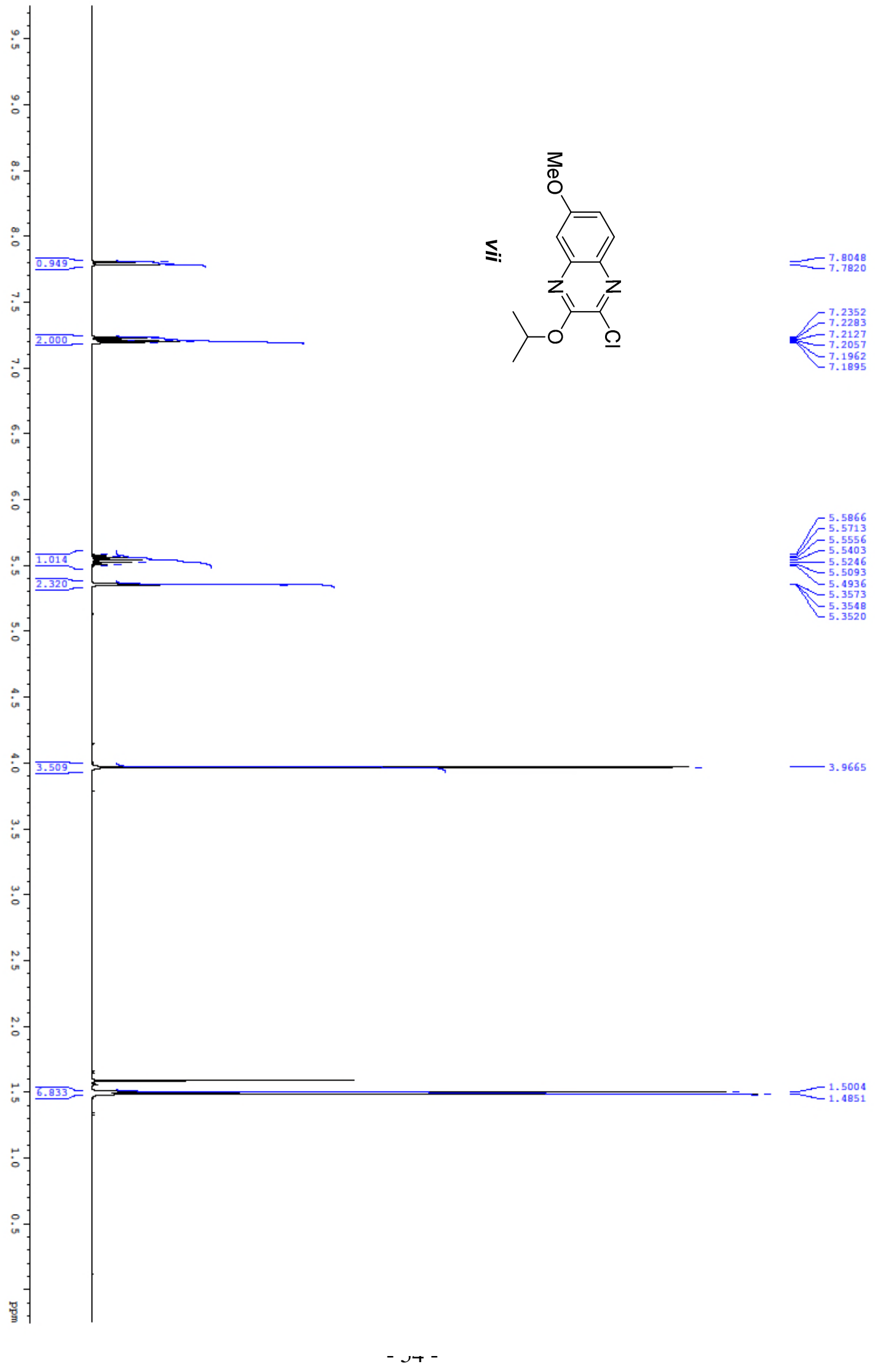




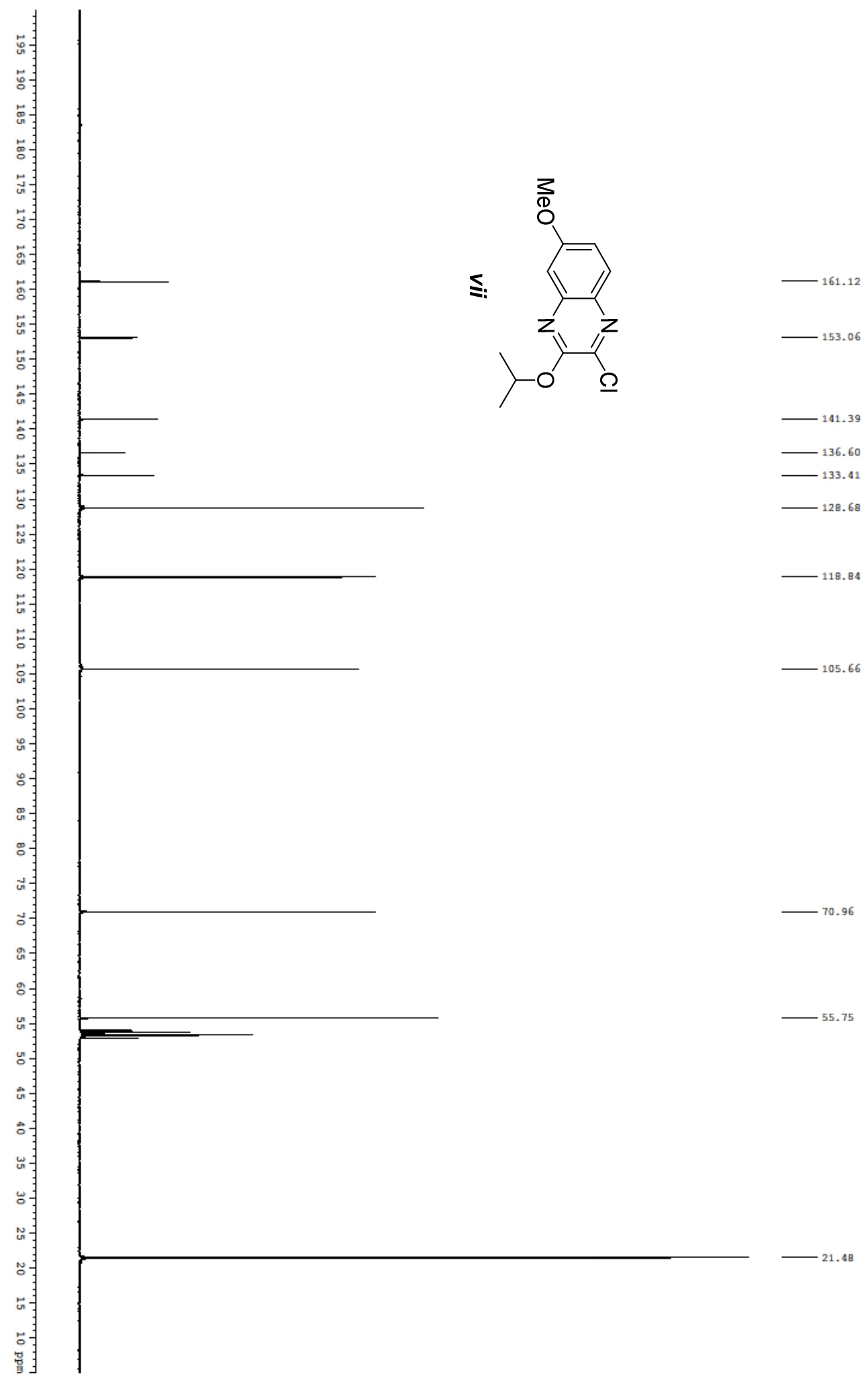

- 55 - 


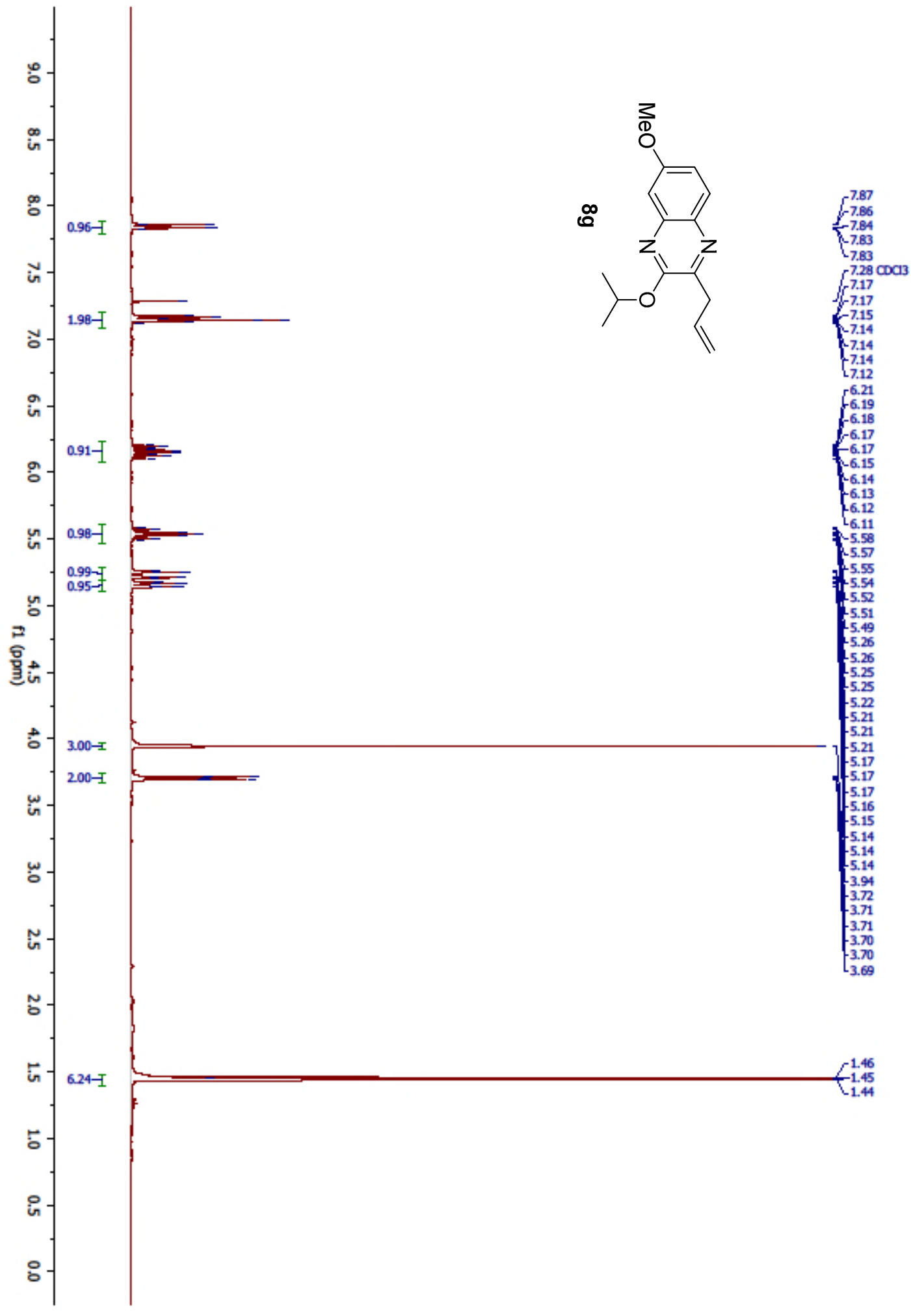




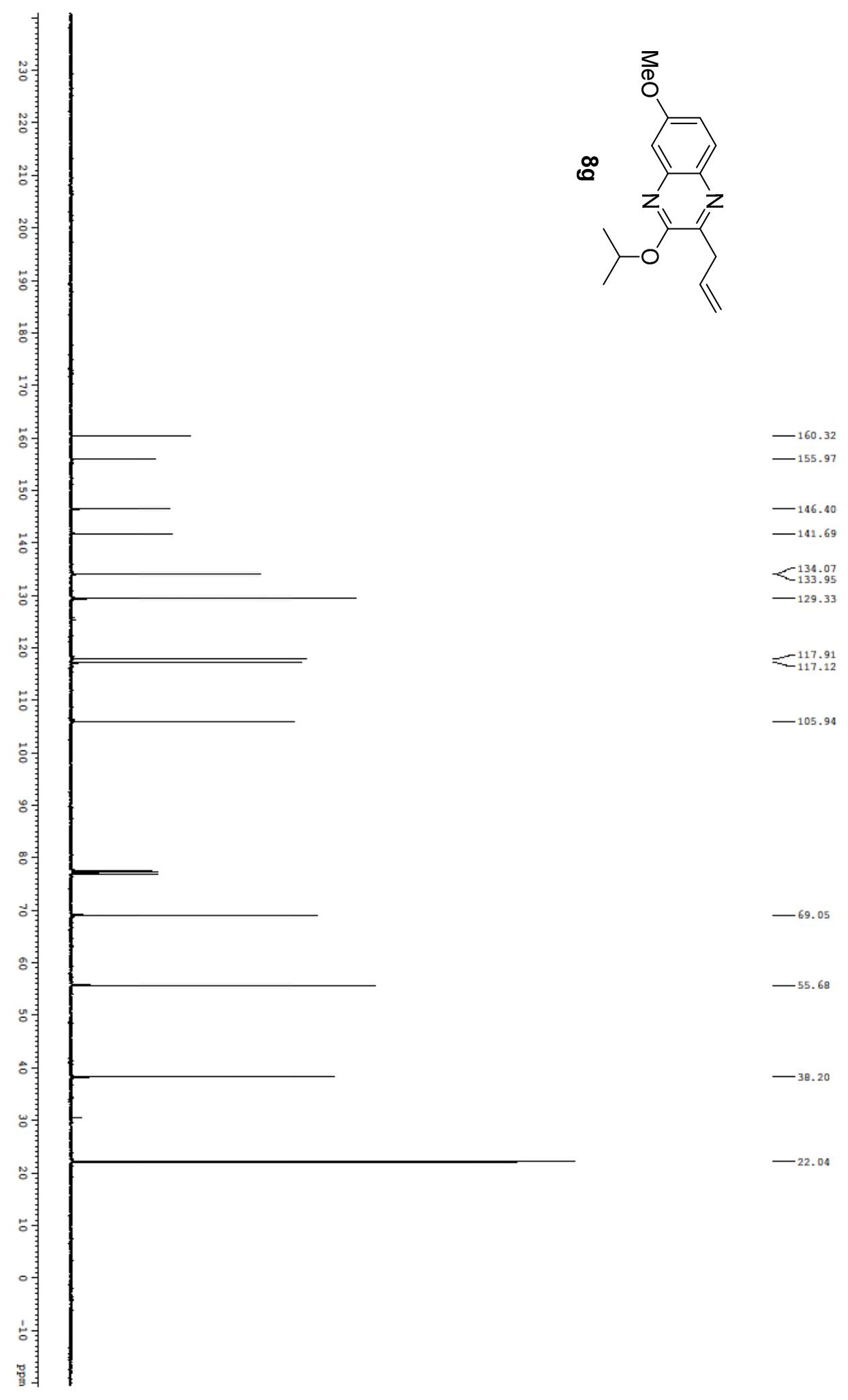




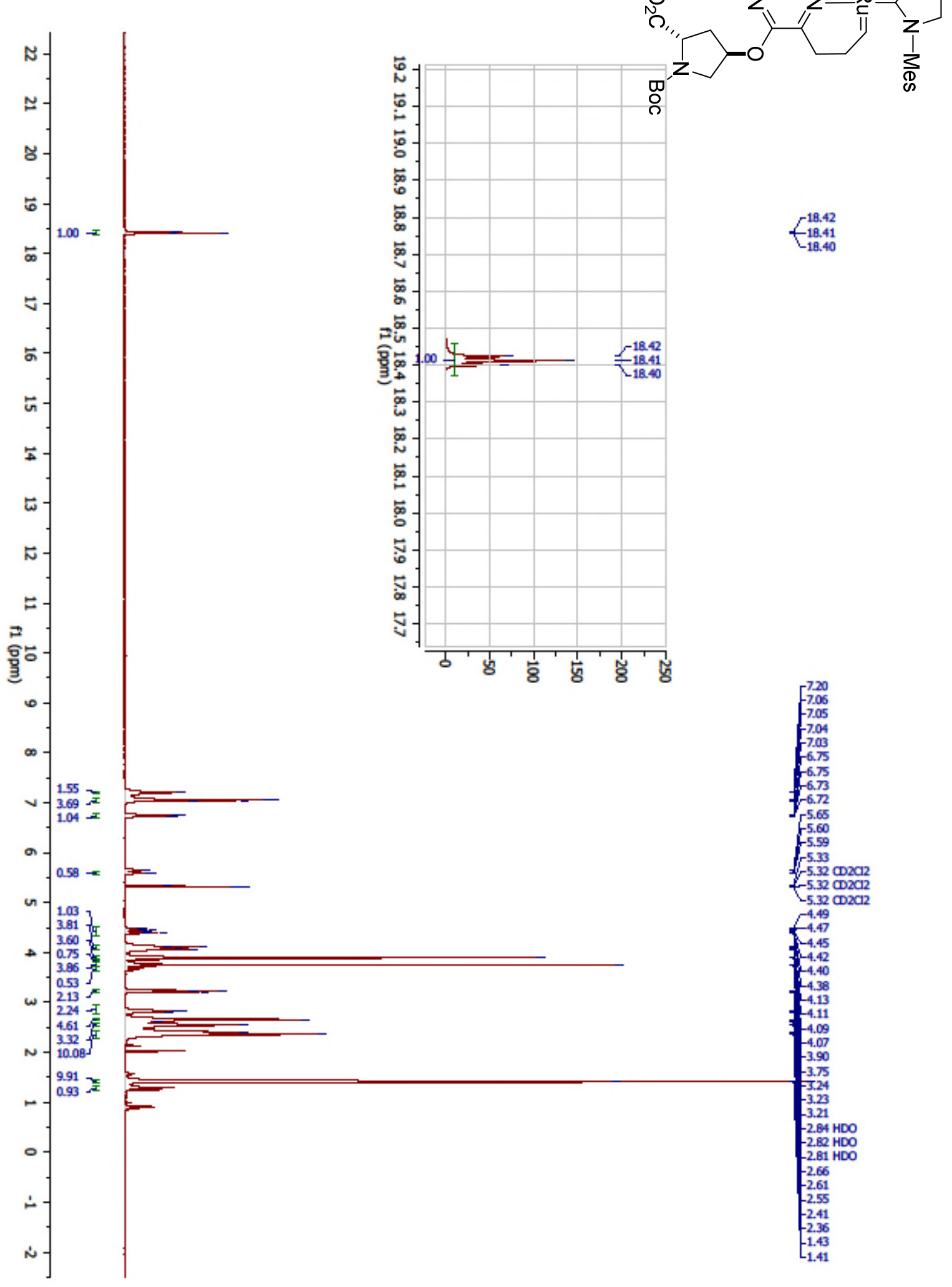




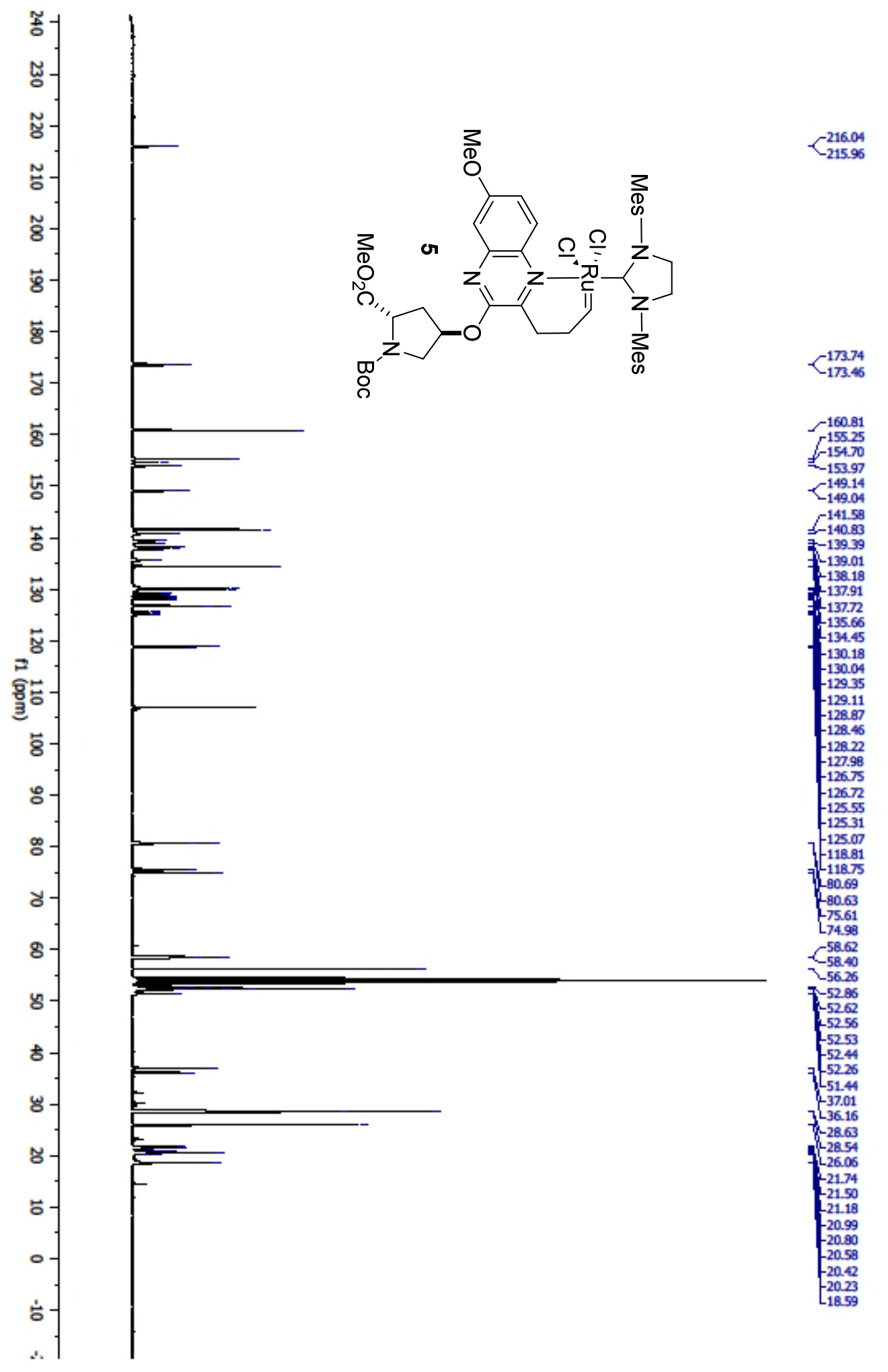




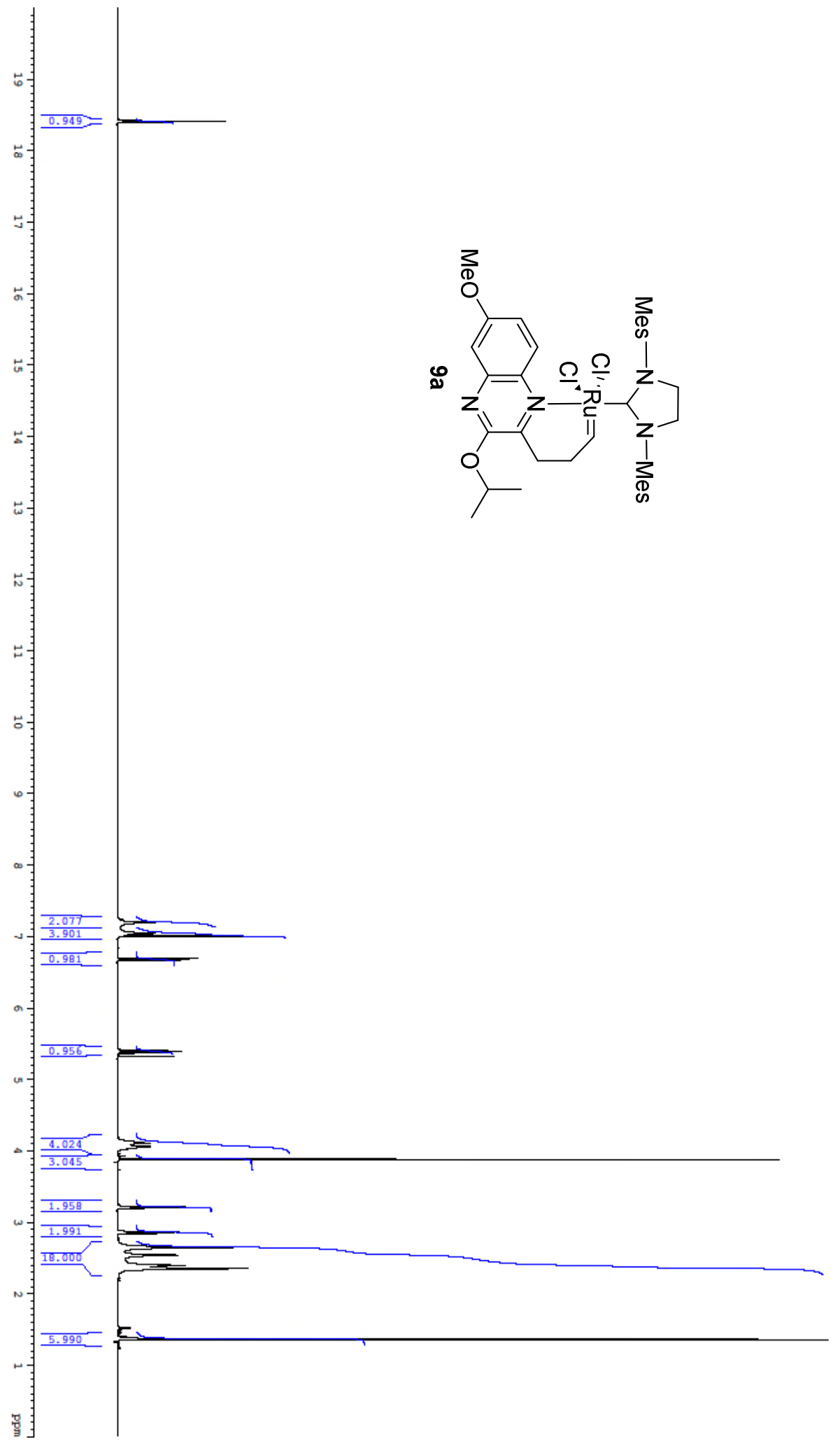




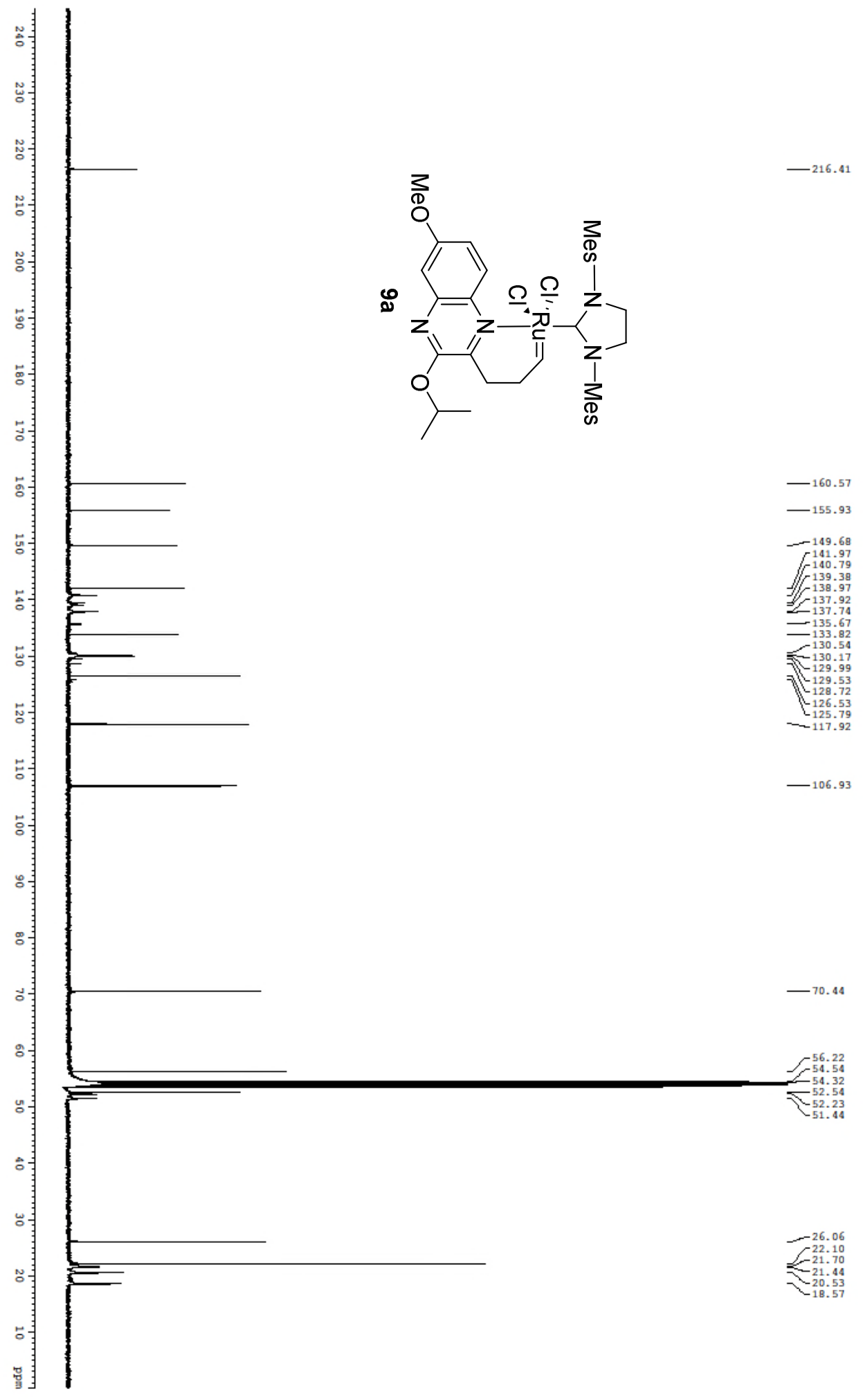

$-61-$ 


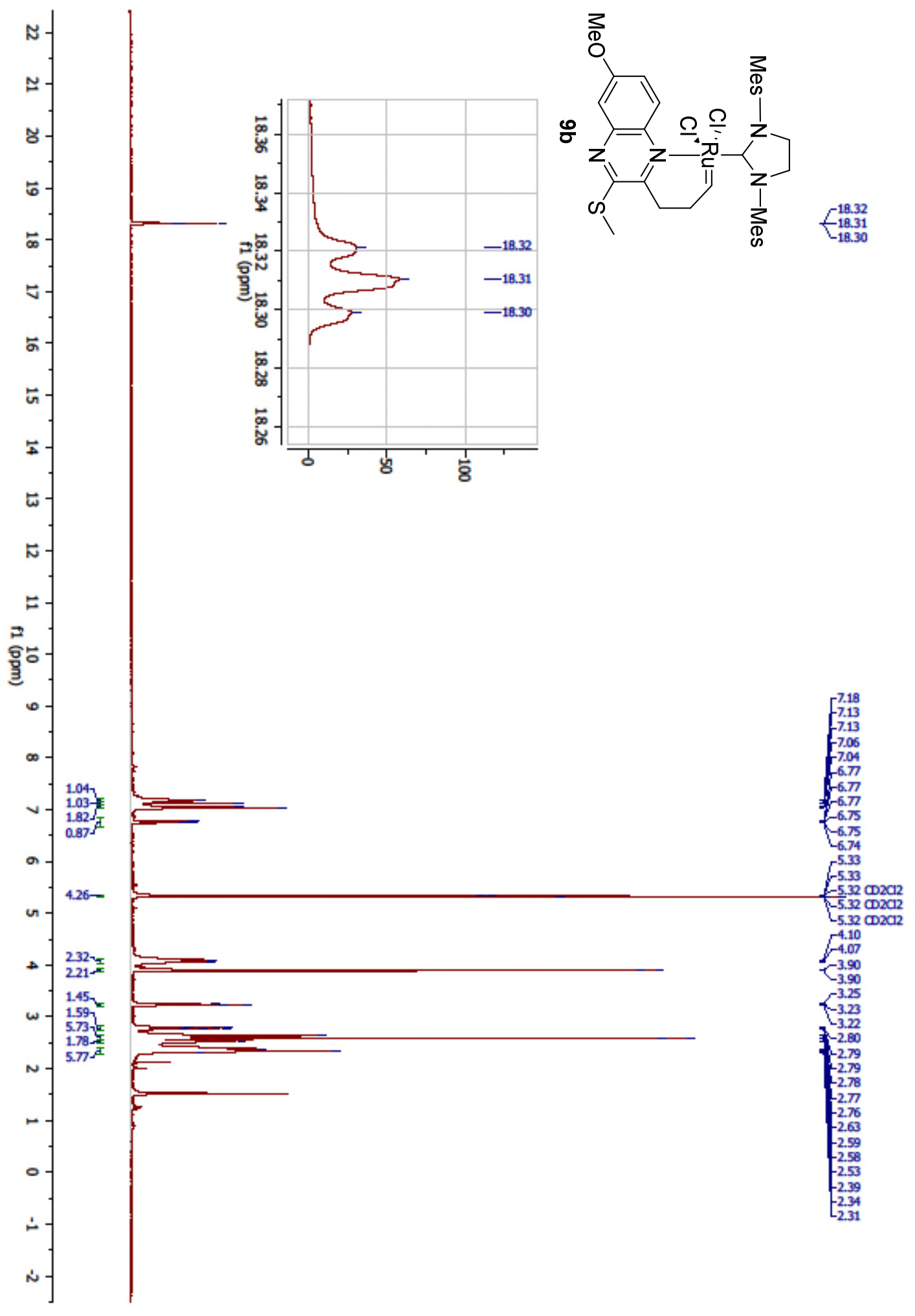




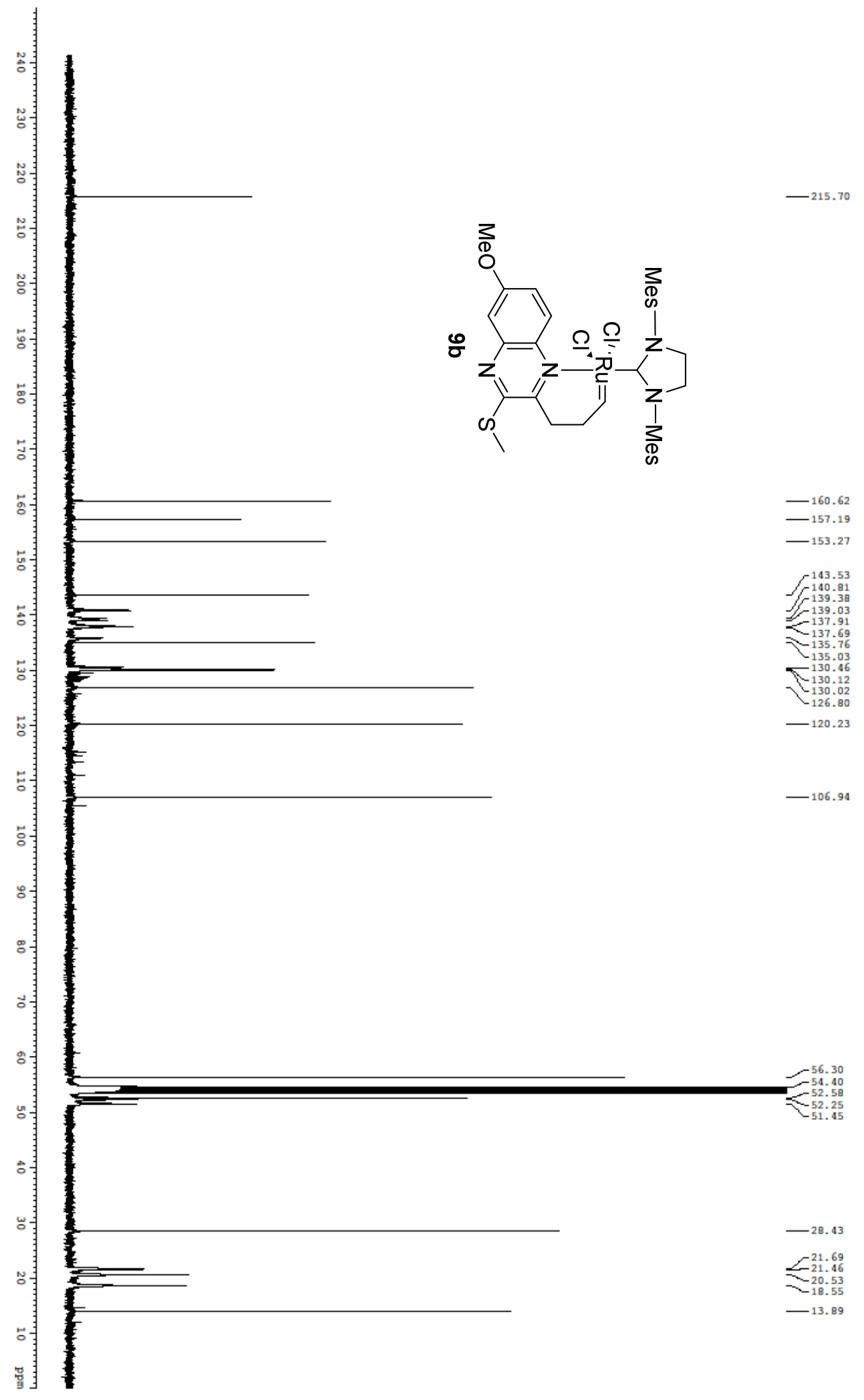

- 63 - 


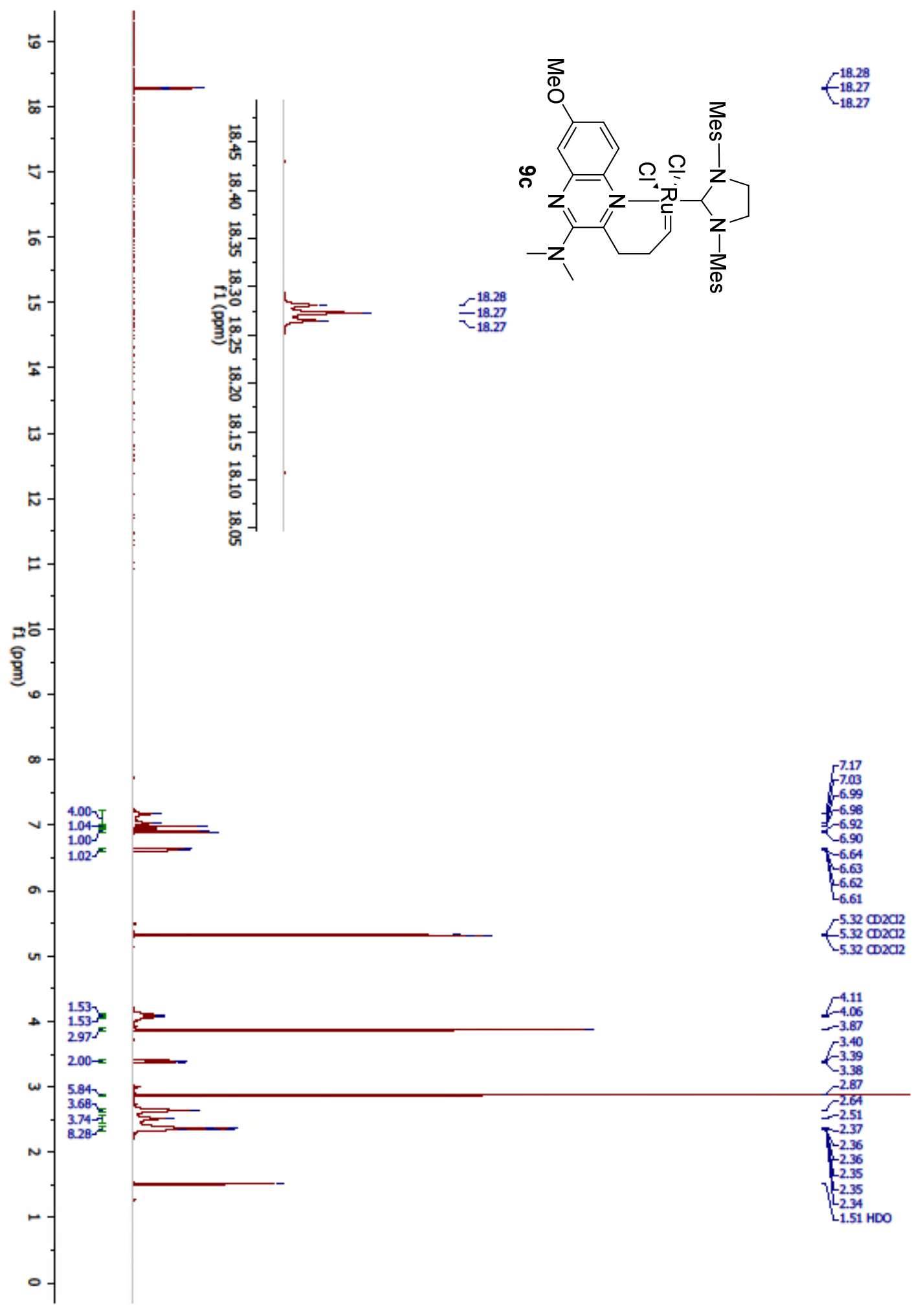




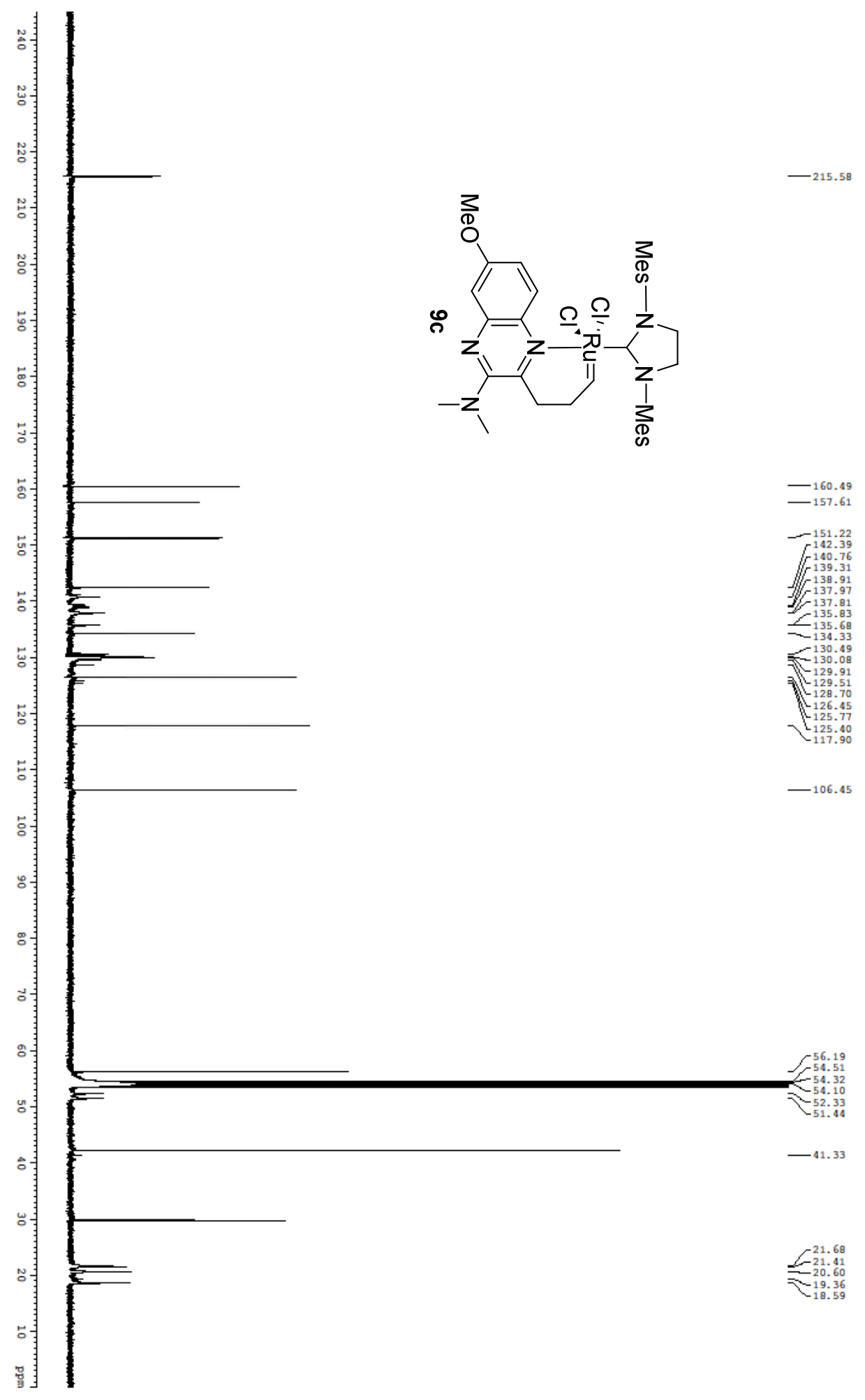

-65 - 


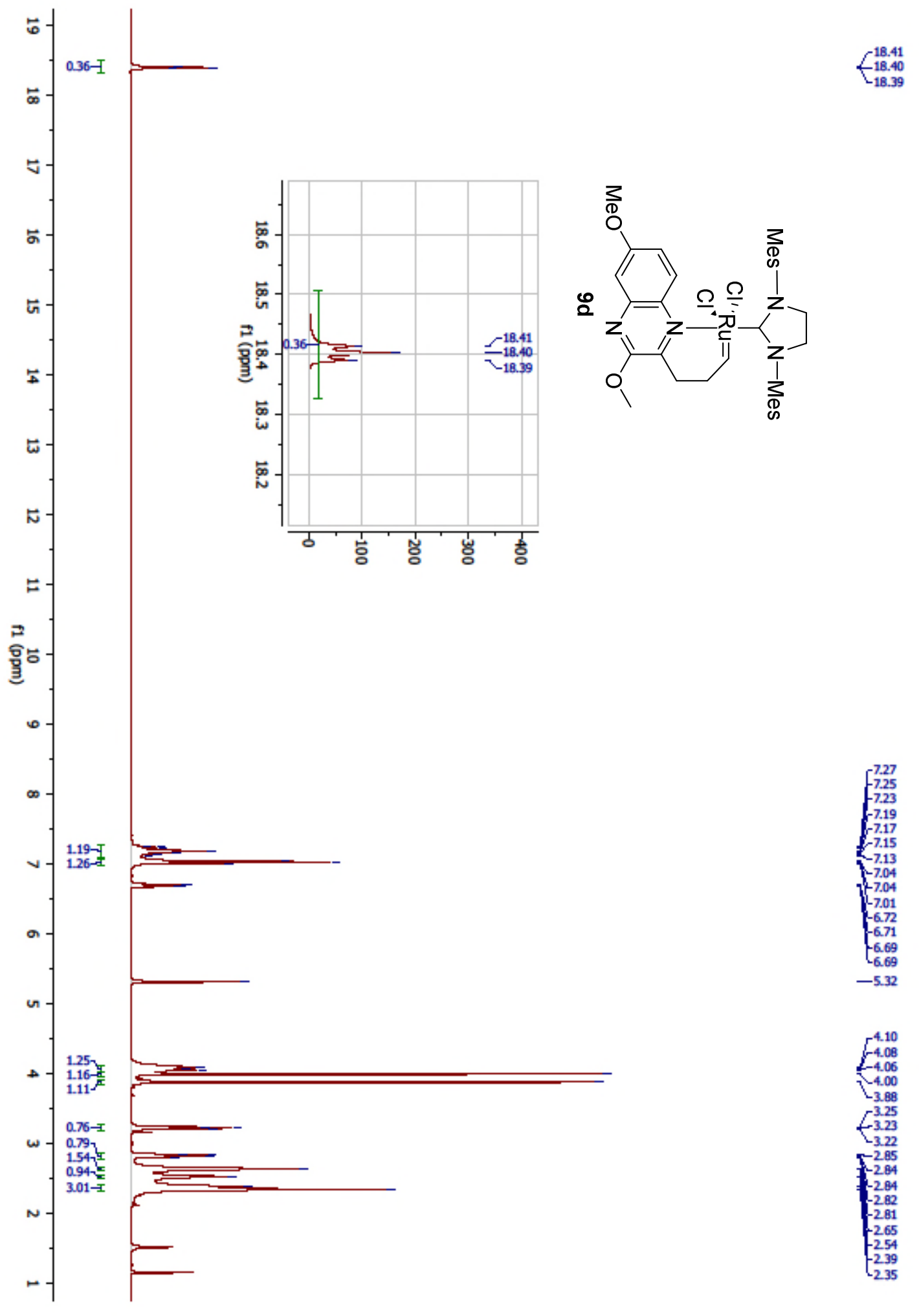




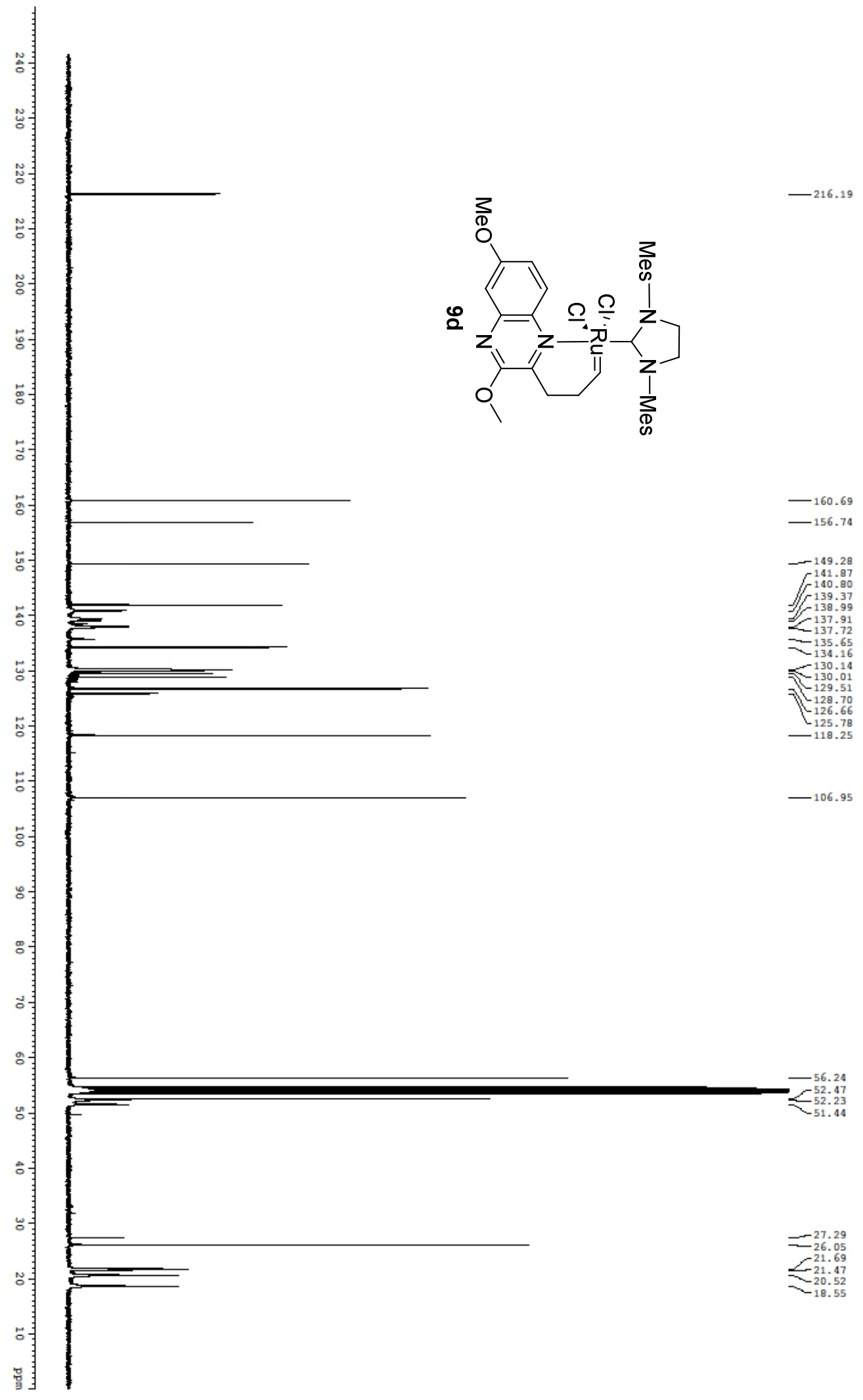




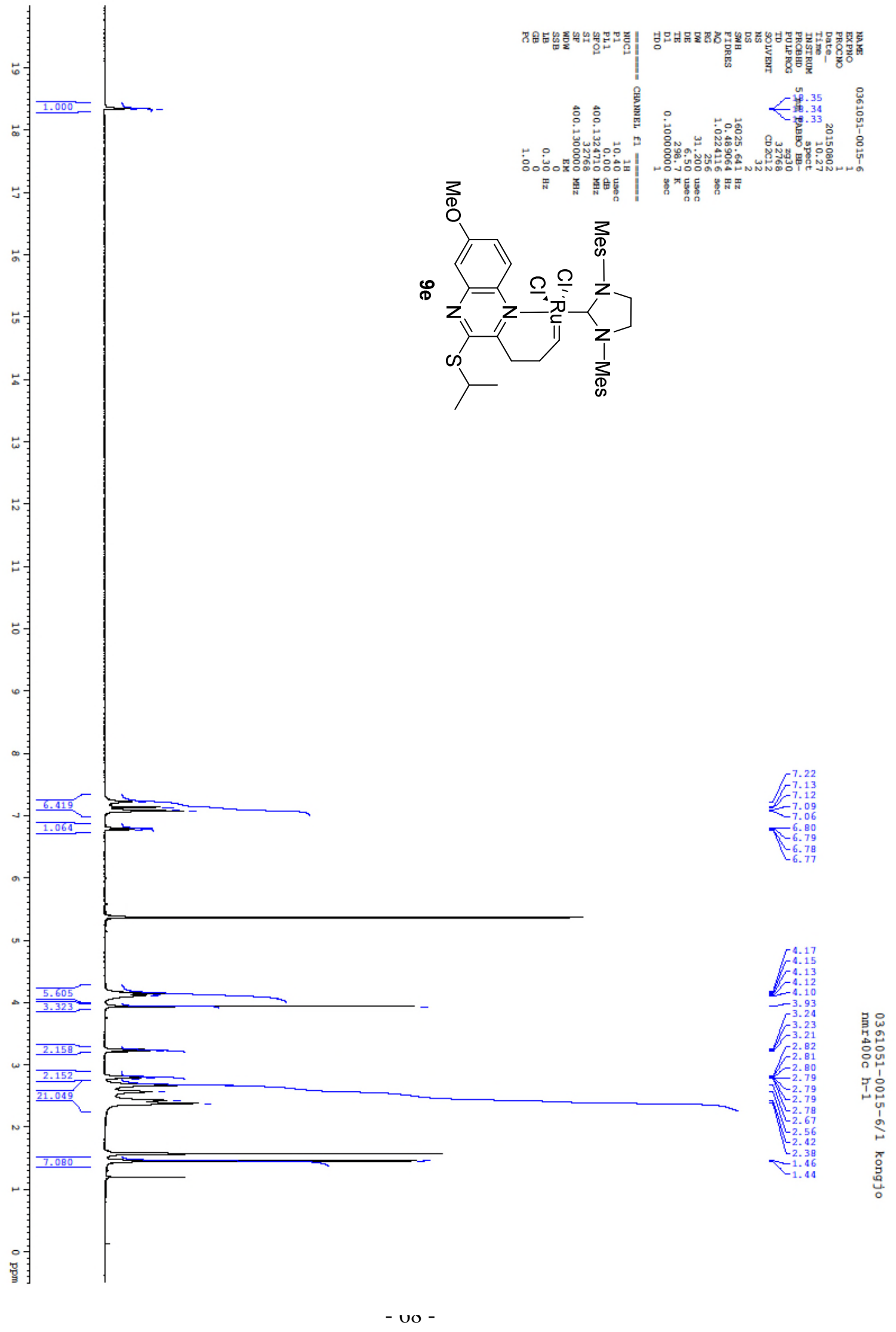




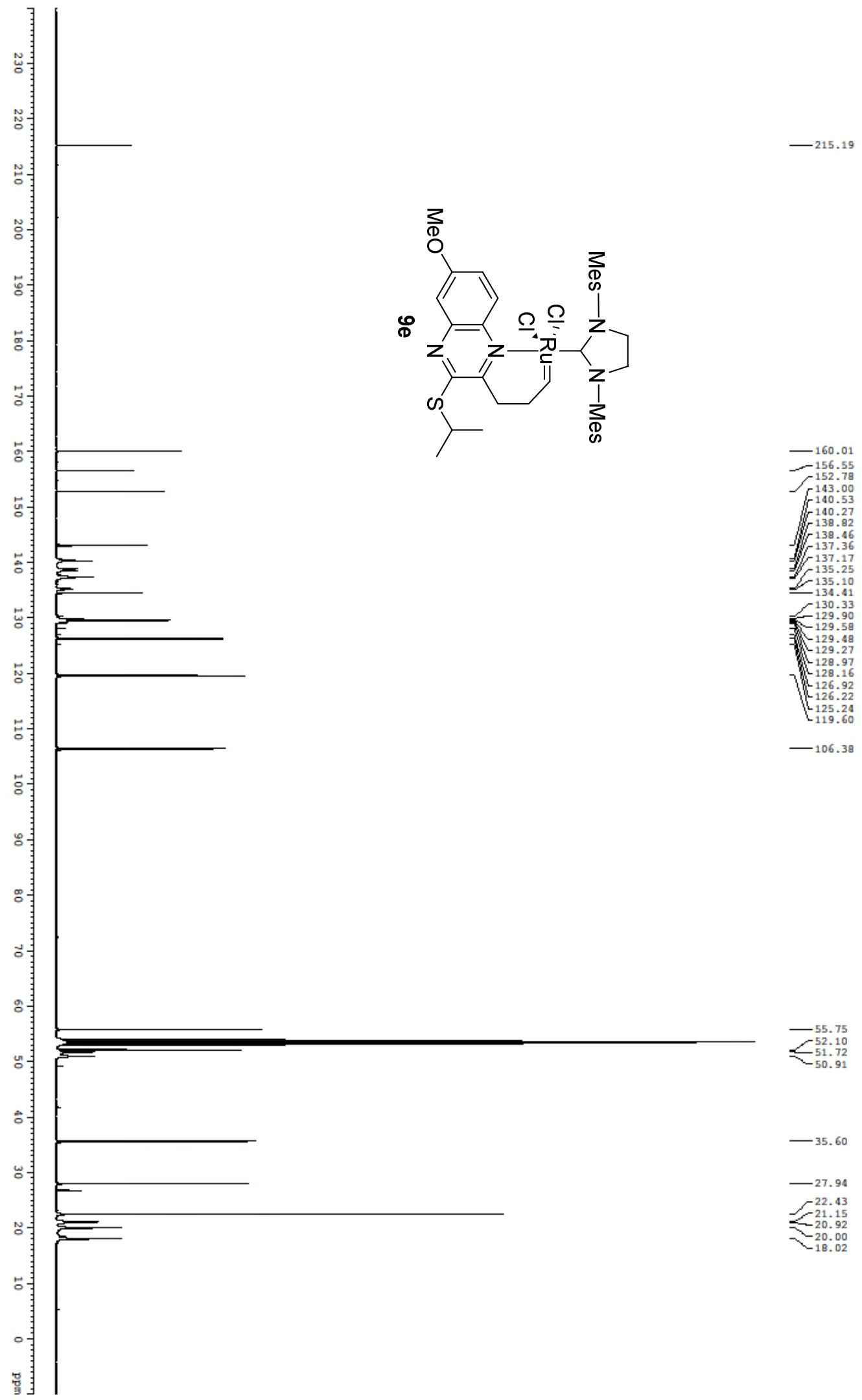




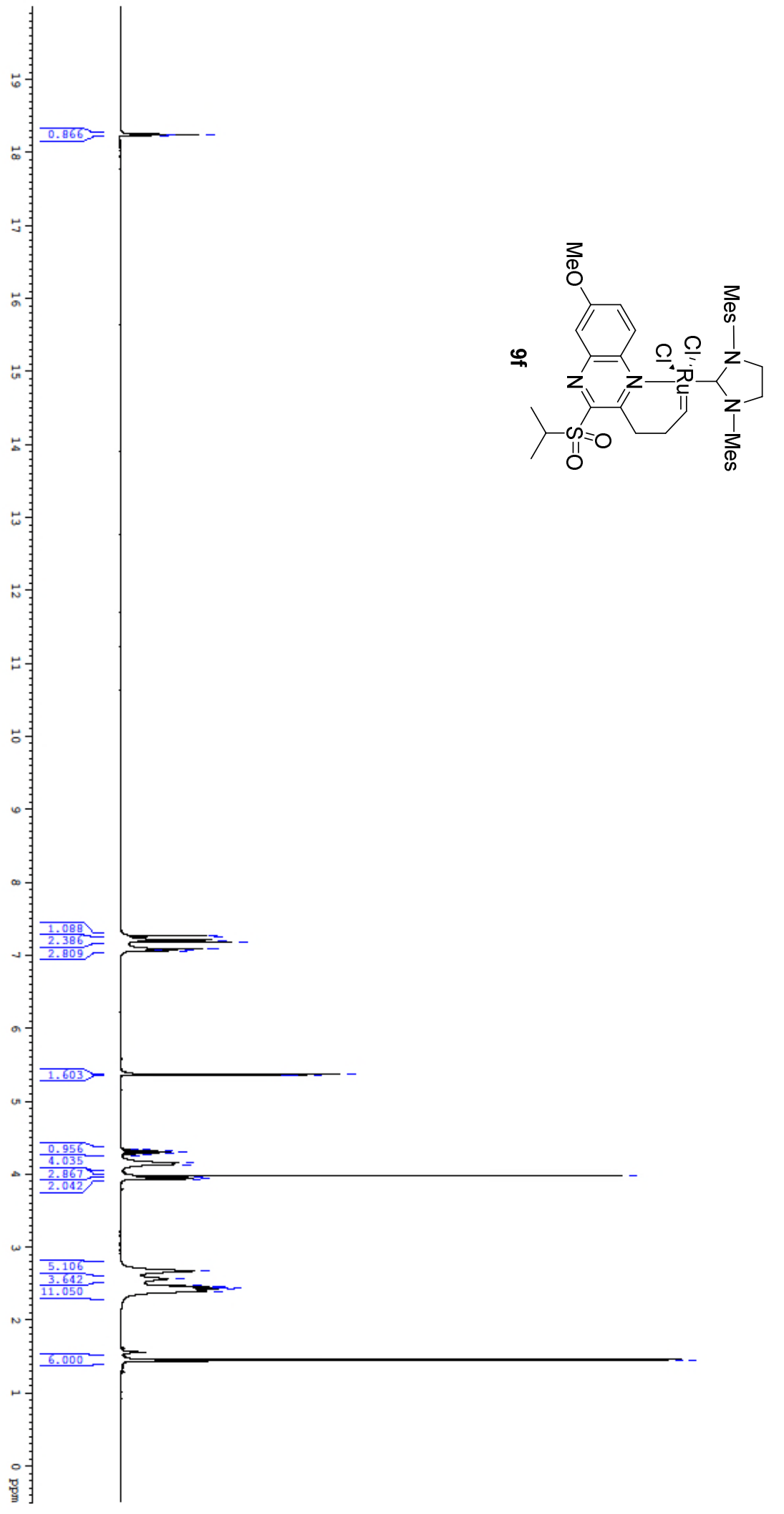




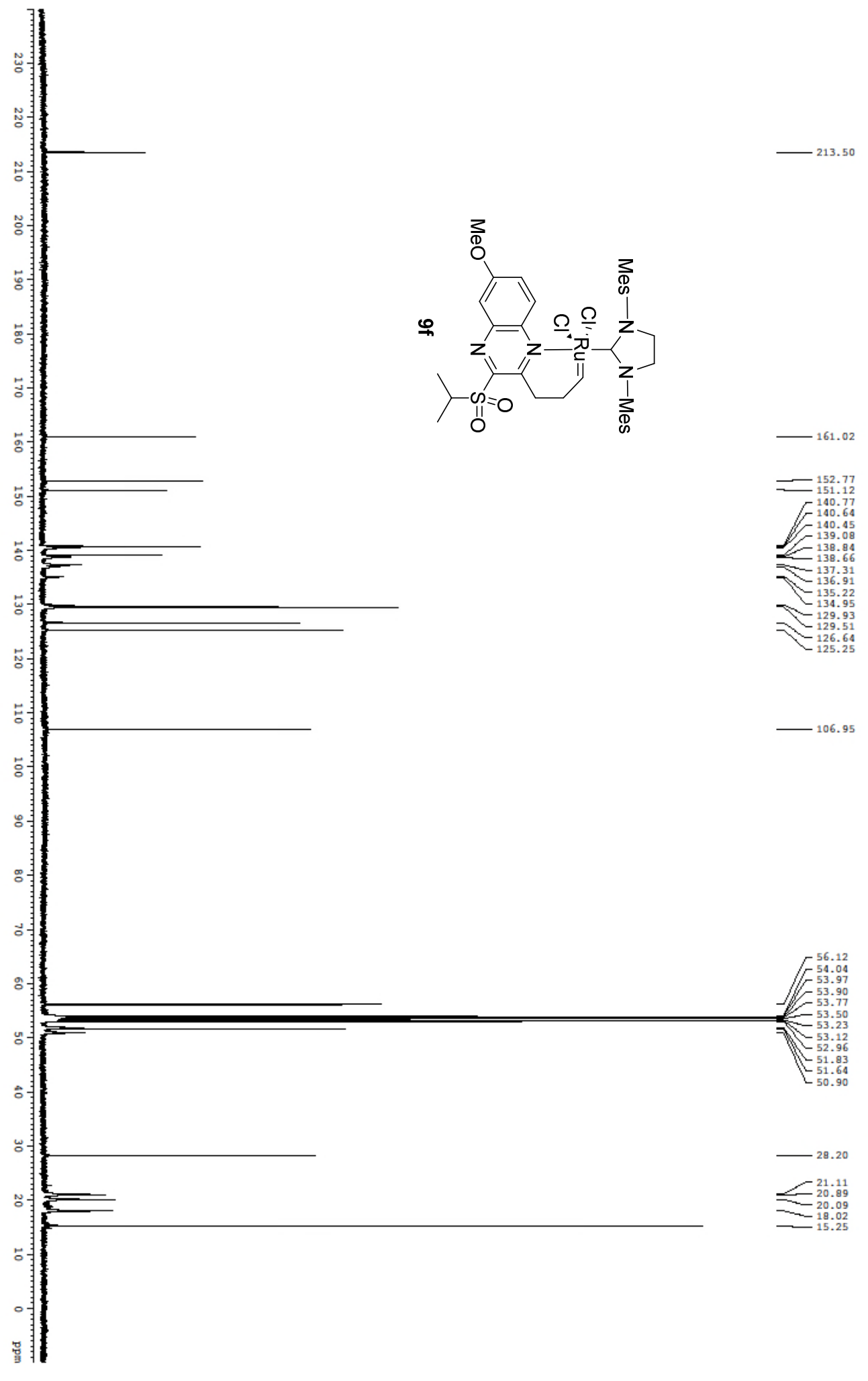




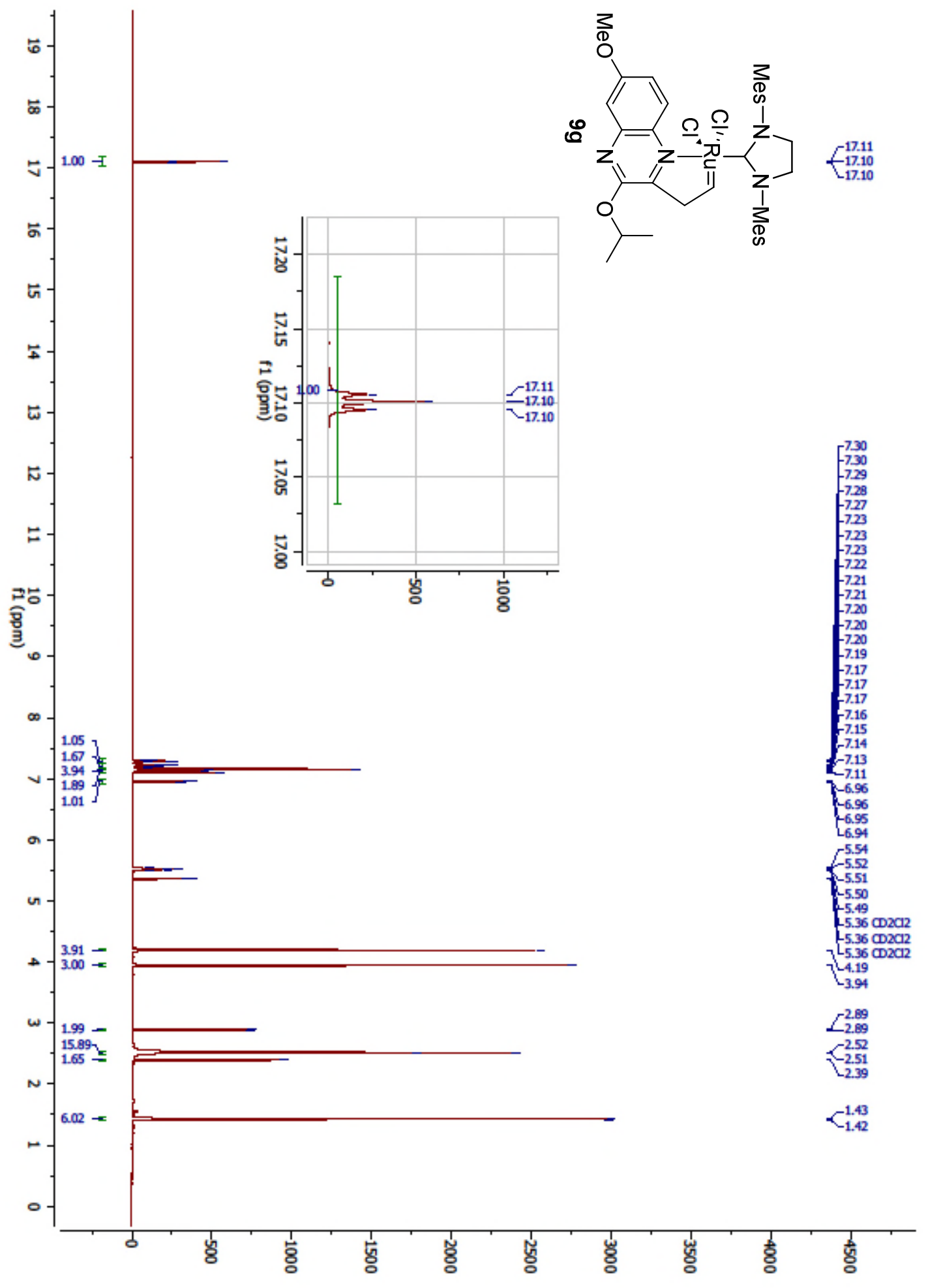




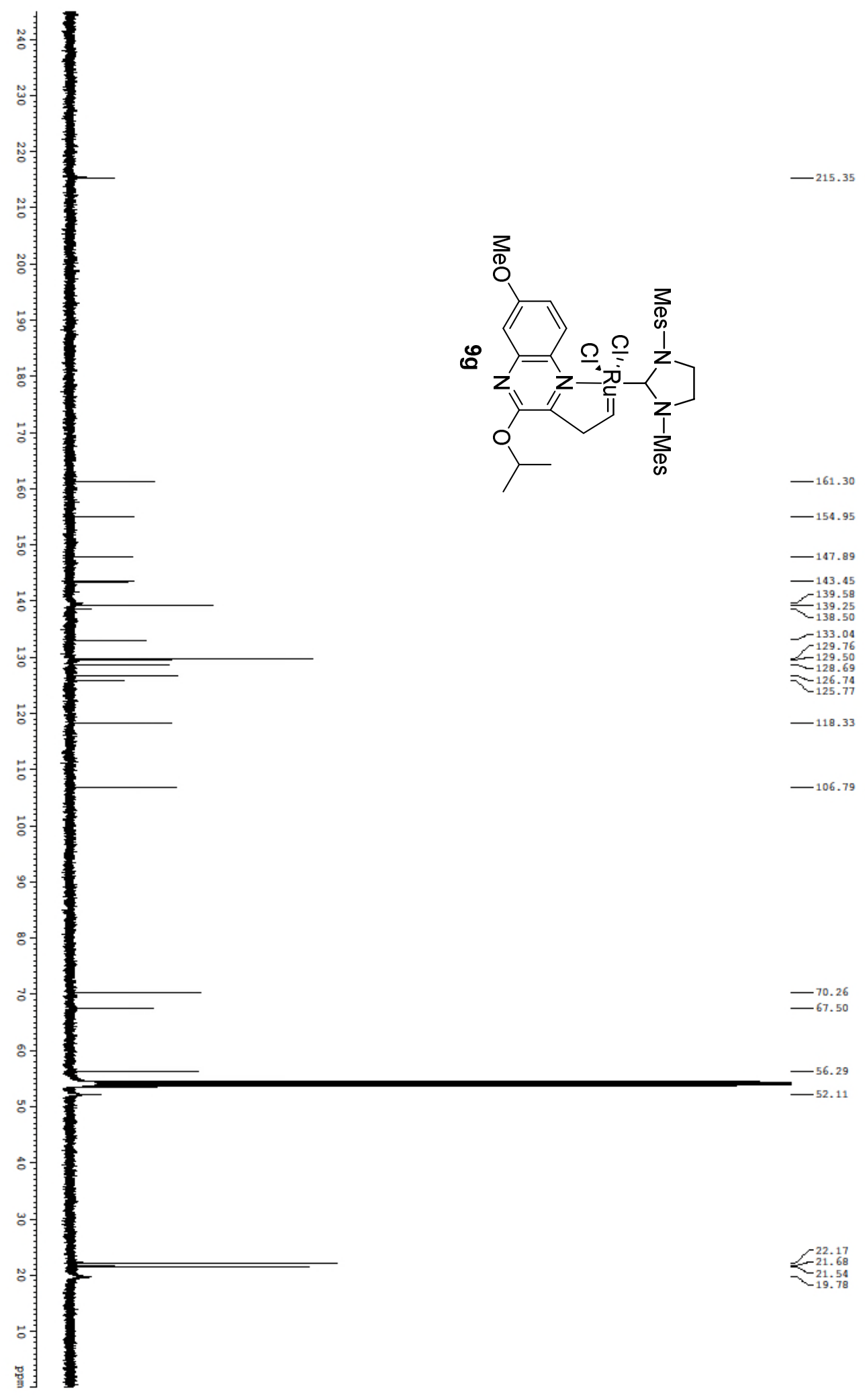



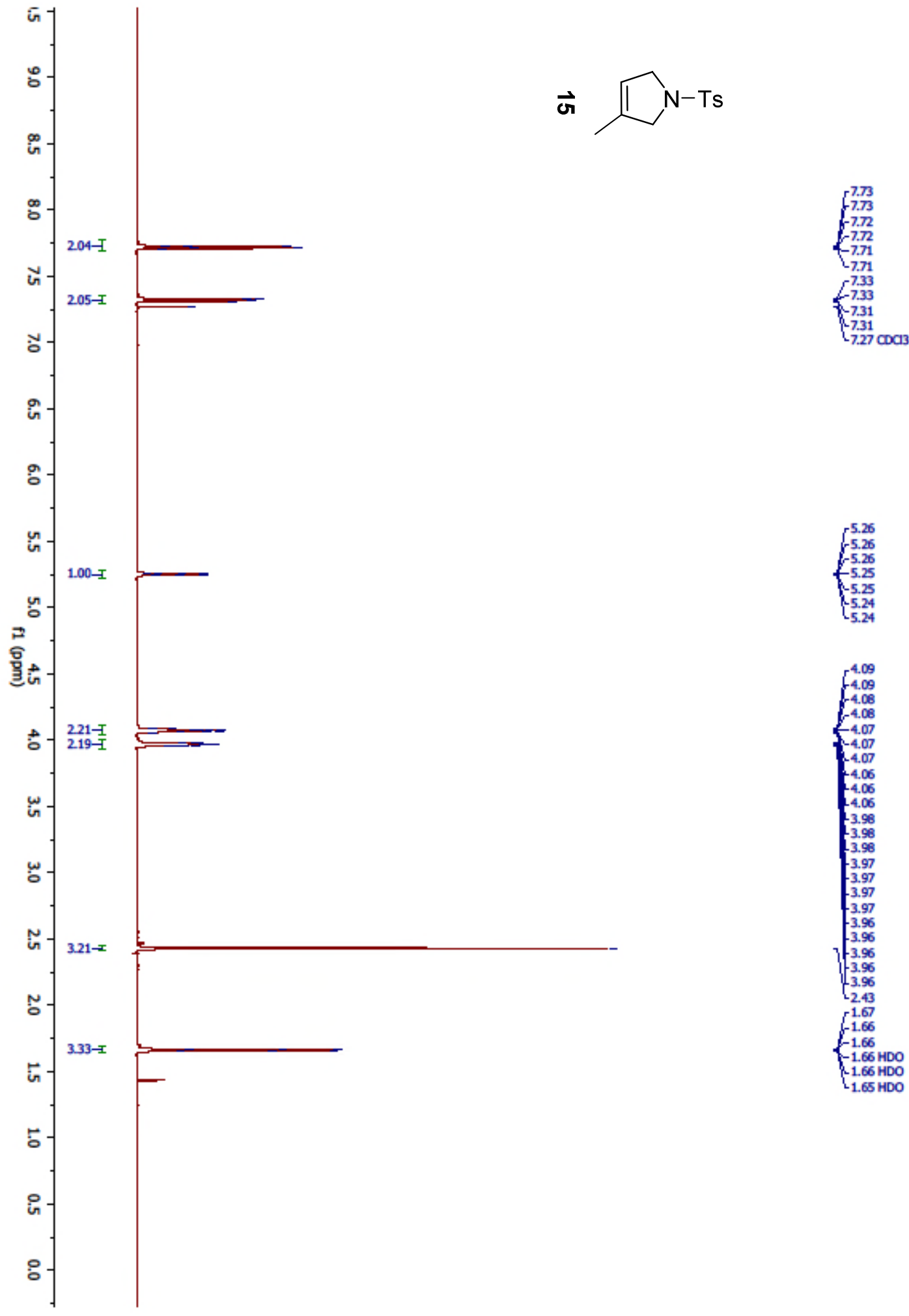

$-4.09$

4.09
4.08
-4.08

-4.08
-4.07

$-4.07$

4.07

4.06
-4.06

$-4.06$

$-3.98$

1.98

$-3.97$

$-3.97$

$-3.97$

3.97

$-2.43$

$r_{-1.67}^{1.66}$

$-1.66$

-1.66
$-1.66 \mathrm{HDO}$

- $1.66 \mathrm{HDO}$

L.65 HDO 